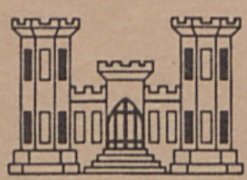

MISCELLANEOUS PAPER S-74-25

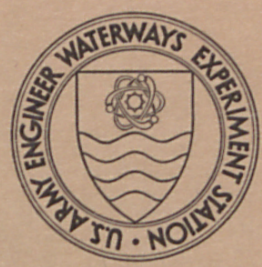

\title{
INVESTIGATION OF TAR-RUBBER PAVEMENT OVERLAYS
}

\author{
by \\ Philip J. Vedros, Jr., Ralph D. Jackson \\ Soils and Pavements Laboratory \\ U. S. Army Engineer Waterways Experiment Station \\ P. O. Box 631, Vicksburg, Miss. 39180
}

November 1974

Final Report

Approved For Public Release; Distribution Unlimited

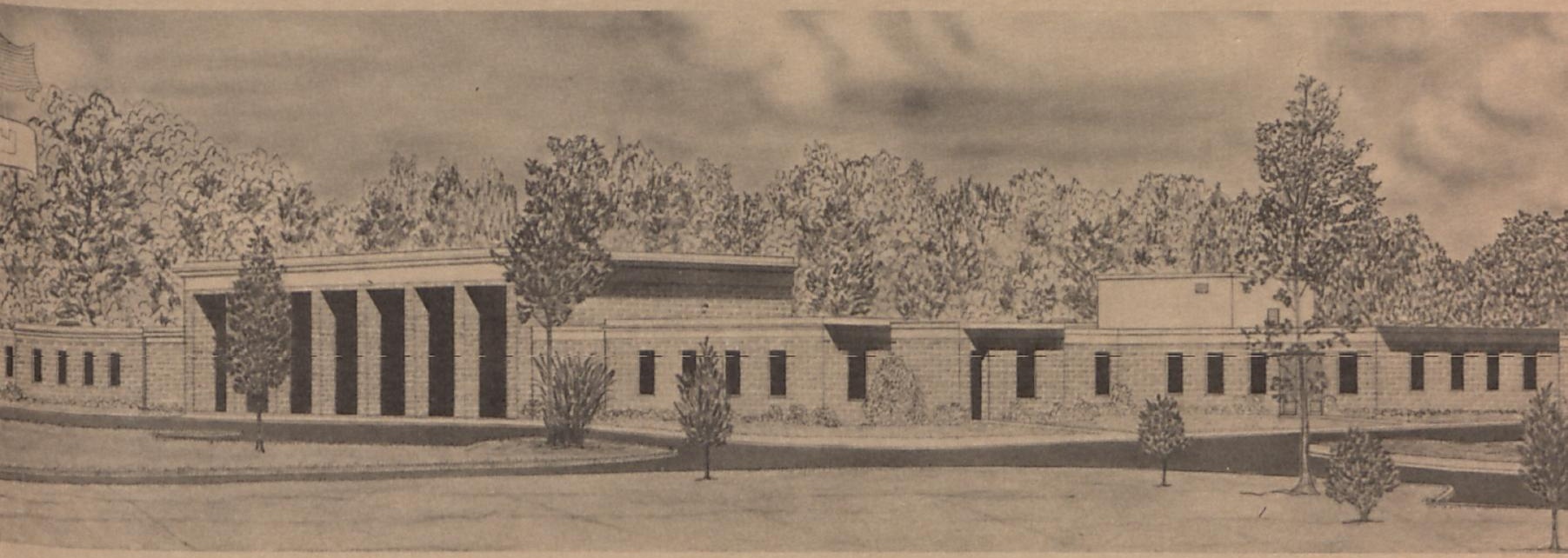

Prepared for Headquarters, U. S. Air Force

Washington, D. C. 20330

Under Project No. PREE-74-1

LIBRARY BRANCH

TECHNICAL INFORMATION CENTER

US ARMY ENGINEER WATERWAYS EXPERIMENT STATION 
Unclassified

SECURITY CLASSIFICATION OF THIS PAGE (When Date Entered)

\begin{tabular}{|c|c|}
\hline REPORT DOCUMENTATION PAGE & $\begin{array}{l}\text { READ INSTRUCTIONS } \\
\text { BEFORE COMPLETING FORM }\end{array}$ \\
\hline $\begin{array}{l}\text { 1. REPORT NUMBER } \\
\text { Miscellaneous Paper S }-74-25\end{array}$ & 3. RECIPIENT'S CATALOG NUMBER \\
\hline \multirow[t]{2}{*}{$\begin{array}{l}\text { 4. TITLE (and Subtitle) } \\
\text { INVESTIGATION OF TAR-RUBBER PAVEMENT OVERLAYS }\end{array}$} & $\begin{array}{l}\text { 5. TYPE OF REPORT A PERIOD COVEREO } \\
\text { Final Report }\end{array}$ \\
\hline & 6. PERFORMING ORG. REPORT NUMBER \\
\hline $\begin{array}{l}\text { 7. AUTHOR(•) } \\
\text { Philip J. Vedros, Jr. } \\
\text { Ralph D. Jackson }\end{array}$ & 8. CONTRACT OR GRANT NUMBER(s) \\
\hline $\begin{array}{l}\text { 9. PERFORMING ORGANIZATION NAME AND ADORESS } \\
\text { U. S. Army Engineer Waterways Experiment Station } \\
\text { Soils and Pavements Laboratory } \\
\text { P. O. Box 631, Vicksburg, Miss. } 39180\end{array}$ & $\begin{array}{l}\text { 10. PROGRAM ELEMENT.PROJECT. TASK } \\
\text { AREA Q WORK UNIT NUMBERS } \\
\text { Project No. PREE-74-1 }\end{array}$ \\
\hline $\begin{array}{l}\text { 11. CONTROLLING OFFICE NAME AND ADDRESS } \\
\text { Headquarters, U. S. Air Force } \\
\text { Washington, D. C. } 20330\end{array}$ & \begin{tabular}{|l|} 
12. REPORT DATE \\
NOVember 1974 \\
13. NUMBER OF PAGES \\
66 \\
\end{tabular} \\
\hline 19. MONITORING AGENCY NAME \& ADDRESS(it dillerent from Controlling Office) & $\begin{array}{l}\text { 15. SECURITY CLASS. (ol this repori) } \\
\text { Unclassified }\end{array}$ \\
\hline & $\begin{array}{l}\text { 15. DECLASSIFICATION/DOWNGRADING } \\
\text { SCHEOULE }\end{array}$ \\
\hline
\end{tabular}

16. DISTRIBUTION STATEMENT (ol thi* Report)

Approved for public release; distribution unlimited.

17. DISTRIBUTION STATEMENT (of the abstract entered in Bluck 20, il different from Report)

18. SUPPLEMENTARY NOTES

19. KEY WOROS (Continue on reverse side if necessary and identify by block number)

Airfield pavements

Overlays (Pavements)

Pavements

Tar rubber

20. ABSTRACT (Concinue on reveree side 18 neceseary and identufy by block number)

The purpose of this study was to determine why tar-rubber pavements are experiencing failures from usage by aircraft with high tire pressures. Failures are in the form of depressions and rutting, raveling of joints, and deterioration from fuel spillage. The study was accomplished by performing pavement field studies and sampling at 10 selected airfields and subjecting the tar-rubber pavement samples from these airfields to a laboratory testing program. The investigation indicated the following: (1) Performance of tar-rubber pavements (Continued) 
20. ABSTRACT (Continued).

is dependent upon the quality of construction and subsequent usage of the pavement. (2) Spillage of $\mathrm{JP}-4$ fuel is more detrimental than spillage of hydraulic fluid on a short-term basis. (3) Use of heavy rubber-tired rollers appears to be necessary during construction in order to meet the density requirements. (4) Tar-rubber pavements perform poorly in all areas adjacent to refueling pits. Based on these findings the following recommendations are considered warranted: (1) Very strict quality control should be enforced during construction so that proper densities can be obtained. (2) Portland cement concrete pavements should be placed in refueling pit areas instead of tar-rubber pavements. (3) Tar-rubber pavements should not be used in aircraft parking areas where tire contact area is less than $100 \mathrm{sq}$ in. and tire pressure is greater than $250 \mathrm{psi}$. (4) Better housekeeping rules should be enforced to minimize deterioration from fuel spillage. 
THE CONTENTS OF THIS REPORT ARE NOT TO BE USED FOR ADVERTISING, PUBLICATION, OR PROMOTIONAL PURPOSES. CITATION OF TRADE NAMES DOES NOT CONSTITUTE AN OFFICIAL ENDORSEMENT OR APPROVAL OF THE USE OF SUCH COMMERCIAL PRODUCTS. 


\section{PREFACE}

The tar-rubber pavement investigation reported herein was conducted under the general supervision of the Pavement Investigations Division, Soils and Pavements Laboratory, U. S. Army Engineer Waterways Experiment Station (WES), Vicksburg, Miss. The study, sponsored by the U. S. Air Force, was conducted during the period October 1973-June 1974. This report was prepared by Messrs. P. J. Vedros, Jr., and R. D. Jackson of the Special Projects Branch under the supervision of Messrs. J. P. Sale, R. G. Ahlvin, R. L. Hutchinson, and A. H. Joseph of the Soils and Pavements Laboratory. Data for the report were obtained from field inspections performed by and laboratory test results compiled by Messrs. R. D. Jackson, S. J. Alford, P. S. McCaffrey, Jr., R. R. Johnson, J. F. Kolb, J. W. Carr, and E. R. Brown.

COL G. H. Hilt, CE, was Director of WES during the conduct of the study and preparation of this report. Mr. F. R. Brown was Technical Director. 
CONTENTS

Page

PREFACE . . . . . . . . . . . . . . . . . . 2

CONVERSION FACTORS, U. S. CUSTOMARY TO METRIC (SI)

UNITS OF MEASUREMENT .............................. 4

PART I: INTRODUCTION ............... 5

Authority . . . . . . . . . . . . . 5

Background ................. 5

Purposes ................... 5

PART II: INSPECTION AND SAMPLING OF AIRFIELDS . . . . . . 6

Homestead AFB, Florida ............ 6

MacDill AFB, Florida .............. 8

Hurlburt AFB, Florida ............... 9

Pope AFB, North Carolina .............. 10

Selfridge AFB, Michigan ............. Il

Forbes AFB, Kansas .............. 13

Mountain Home AFB, Idaho ............. 15

Langley AFB, Virginia .............. 16

Wright-Patterson AFB, Ohio ............ 18

Rickenbacker AFB, Ohio ............. 19

PART III: ANALYSIS OF FINDINGS . . . . . . . . . . 21

Materials . . . . . . . . . . . . . 21

Compaction ................. 22

Effects of $\mathrm{JP}-4$ and Hydraulic Fluid ......... 23

PART IV: SUMMARY OF RESULTS AND RECOMMENDATIONS . . . . . . 25

TABIES I-2

PHOTOS 1-41

PLATES $1-13$ 
CONVERSION FACTORS, U. S. CUSTOMARY TO METRIC (SI)

UNITS OF MEASUREMENT

U. S. customary units of measurement used in this report can be converted to metric (SI) units as follows:

\begin{tabular}{lccl}
\multicolumn{1}{c}{ Multiply } & By & & \multicolumn{1}{c}{ To Obtain } \\
inches & 2.54 & & centimeters \\
square inches & 6.4516 & & square centimeters \\
feet & 0.3048 & & meters \\
pounds (mass) & 0.4535924 & kilograms \\
pounds (force) & 4.448222 & & newtons \\
pounds per square inch & 0.6894757 & & newtons per square centimeter \\
pounds per cubic foot & 16.01846 & & kilograms per cubic meter \\
tons (2000 lb) & 907.1847 & & kilograms \\
Fahrenheit degrees & $5 / 9$ & & Celsius degrees or Kelvins*
\end{tabular}

* To obtain Celsius (C) temperature readings from Fahrenheit ( $F$ ) readings, use the following formula: $C=(5 / 9)(F-32)$. To obtain Kelvin $(K)$ readings, use: $K=(5 / 9)(F-32)+273.15$. 


\section{PART I: INTRODUCTION}

\section{Authority}

1. Authority for conducting investigations of tar-rubber pavement overlays at selected airfields is contained in Headquarters, U. S. Air Force, Project Order No. PREE-74-1, dated 15 October 1973.

\section{Background}

2. Tar-rubber and tar concrete have been used for a number of years as acceptable overlays for the resurfacing of asphaltic concrete and portland cement concrete (PCC) in aircraft parking areas subjected to fuel spillage. Tar-rubber and tar concrete can be economically placed on old, deteriorated pavements. However, a number of failures have been observed in tar-rubber pavements on parking and refueling aprons. These failures have been in the form of depressions and rutting from high-pressure tires, raveling of joints, and deterioration from fuel spillage. A number of airfields at which tar-rubber has been placed were selected for this investigation to study the performance of the tar-rubber pavements.

\section{Purposes}

3. The purposes of this investigation were as follows:

a. To determine conditions of tar-rubber overlays at ten selected airfields.

b. To determine by laboratory testing the effects of hydraulic fluids and jet fuels on tar-rubber pavements.

c. To determine the effects of aircraft with high-pressure tires on tar-rubber pavements.

d. Based on technical analysis of all observations, studies, tests, and evaluations, to recommend changes, if applicable, in present Air Force criteria and manuals. 
4. During the period 6 December 1973 to 11 April 1974, ten airfields were visited, and core samples of tar-rubber pavements were obtained. Fields visited were Homestead Air Force Base (AFB), Florida; MacDill AFB, Florida; Hurlburt AFB, Florida; Pope AFB, North Carolina; Langley AFB, Virginia; Rickenbacker AFB, Ohio; Wright-Patterson AFB, Ohio; Selfridge AFB, Michigan; Forbes AFB, Kansas; and Mountain Home $A F B$, Idaho. Core samples were obtained from pavements of each construction year at each airfield. The samples were selected from areas showing deterioration, such as rutting and fuel spillage, and from paving joints. Pertinent photographs of the condition of the pavements were made during the investigation. The core samples were returned to the U. S. Army Engineer Waterways Experiment Station (WES) and subjected to laboratory testing. Tests consisted of density, gradation, specific gravity, bitumen content, stability, flow, and computation of voids determinations. Samples were also soaked in hydraulic fluid and jet fuel $(\mathrm{JP}-4)$ to determine the effects of these liquids on the tarrubber. Results of the laboratory tests are shown in Tables 1 and 2.

Homestead AFB, Florida

5. The tar-rubber pavements at Homestead AFB were constructed during the years 1955-56 and 1967. The 1955 pavements were placed on the large parking apron, and the pavement structure consisted of a 1-1/2-in.* tar-rubber surface course, a 2-1/2-in. asphaltic concrete binder course, and 6 in. of crushed limestone base course on existing limerock subgrade. The approved job-mix formula for the tar-rubber surface course was as follows:

* A table of factors for converting U. S. customary units of measurement to metric (SI) units is given on page 4. 


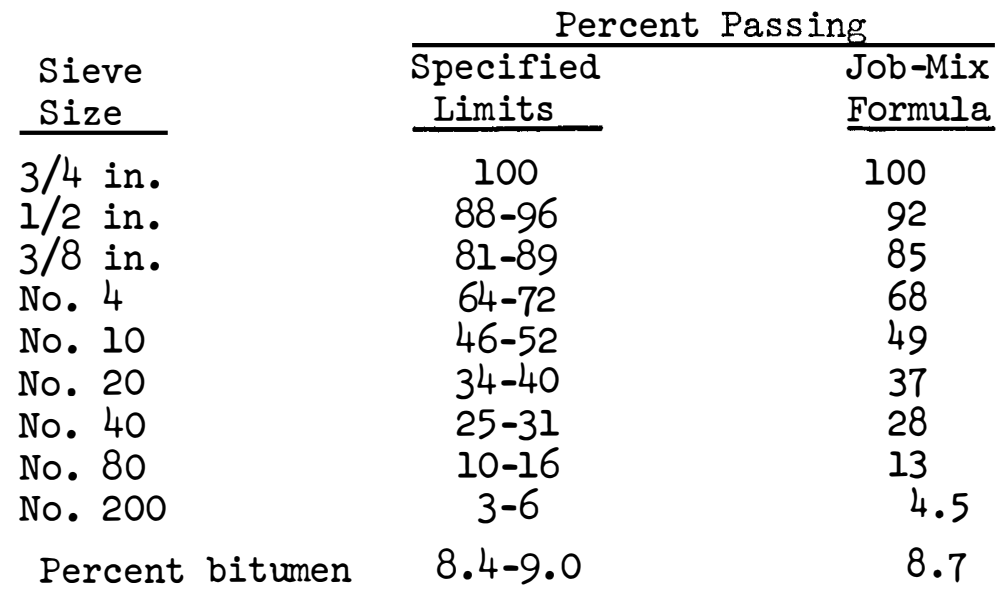

The Sulfa-Aero-Sealz 3080A tar-rubber blend was furnished by the U. S. Rubber Company and blended at the plant of the Reilly Tar and Chemical Company, Rahway, New Jersey. For compaction after laydown of the tarrubber pavement, two three-wheel, 10-ton rollers and two tandem (8- to 12-ton) rollers were used. Intermediate rolling was accomplished with a Bros self-propelled rubber-tired roller loaded to approximately 8 tons. 6. In 1967, due to pavement deterioration around refueling pits and depressions in the surface caused by traffic of B-47 aircraft, areas of the 1955 tar-rubber pavement were removed and replaced with new tarrubber pavement. The approved job-mix formula for the new tar-rubber surface course was as follows:

\begin{tabular}{|c|c|c|}
\hline \multirow[b]{2}{*}{$\begin{array}{l}\text { Sieve } \\
\text { Size }\end{array}$} & \\
\hline & $\begin{array}{l}\text { Specified } \\
\text { Limits } \\
\end{array}$ & $\begin{array}{l}\text { Job-Mix } \\
\text { Formula }\end{array}$ \\
\hline $3 / 4$ in. & 100 & 100 \\
\hline $1 / 2$ in. & $82-96$ & 88 \\
\hline $3 / 8$ in. & $75-90$ & 82 \\
\hline No. 4 & $60-73$ & 62 \\
\hline No. 8 & $46-60$ & 47 \\
\hline No. 16 & $34-48$ & 39 \\
\hline No. 30 & $24-38$ & 34 \\
\hline No. 50 & $16-28$ & 26 \\
\hline No. 100 & $8-18$ & 10 \\
\hline No. 200 & $3-6$ & 5.3 \\
\hline Percent & & 8.7 \\
\hline
\end{tabular}

7. The 1955 pavements had been used by all types of aircraft, such as heavy bombers, tankers, and cargo and fighter aircraft. Mostly 
fighter-type aircraft (F-106 and F-4) have used the 1967 pavements. At the time of this investigation, the 1955 tar-rubber pavements were in 'poor to fair condition with considerable cracking (Photo 1) and roughness occurring adjacent to the cracks (Photos 2 and 3 ). The pavements began cracking approximately 2 years after placement and have progressively deteriorated over the years. Rutting was occurring in the taxiway area of the apron (Photo 4). In areas where the F-106 and F-4 aircraft had been parking on the 1967 tar-rubber pavements, the surface had depressed and ponding of fuel and hydraulic fluid in these areas had caused the surface to deteriorate to the point that removal of the pavement was necessary. At the time of this investigation, most of the 1967 tar-rubber pavements had been removed and replaced with PCC pavement. The core samples of the 1967 pavements obtained in this investigation were from small areas of pavement that had not been removed and that were not being used by aircraft.

\section{MacDill AFB, Florida}

8. In 1970-71, tar-rubber pavements were placed on parking areas at MacDill AFB. In one area, an existing overlay of asphaltic concrete pavement was removed from the underlying PCC pavement and replaced with a 2-1/2-in. tar-concrete binder course and a 1-1/2-in. tar-rubber course. In the remaining areas, a 6-in.-thick asphaltic concrete pavement was removed from the underlying 6-in. PCC and replaced with a 4-1/2-in. tar-concrete binder course and a 1-1/2-in. tar-rubber surface course. The approved job-mix formula for the tar-rubber surface course was as tabulated on the following page. The tar-rubber blend was furnished by the Koppers Company and blended at their plant in Garwood, New Jersey. For compaction, a 10-ton tandem roller was used for breakdown, a 25-ton rubber-tired roller for intermediate rolling, and a 12-ton tandem for final rolling.

9. The pavement area on which the bituminous pavement (4-1/2-in. tar concrete and 1-1/2-in. tar-rubber) had been placed had not received as much traffic usage as the other areas and was therefore in fair 


\begin{tabular}{lcc} 
& \multicolumn{2}{c}{ Percent } \\
\cline { 2 - 3 } Sieve & $\begin{array}{c}\text { Specified } \\
\text { Simits }\end{array}$ & $\begin{array}{c}\text { Job-Mix } \\
\text { Formula }\end{array}$ \\
\cline { 2 - 3 } 1/2 in. & 100 & 100 \\
3/8 in. & $79-94$ & 89 \\
No. 4 & $59-73$ & 63 \\
No. 8 & $46-60$ & 57 \\
No. 16 & $34-48$ & 40 \\
No. 30 & $24-38$ & 28 \\
No. 50 & $16-28$ & 20 \\
No. 100 & $8-18$ & 10 \\
No. 200 & $3-6$ & 5.0 \\
Percent bitumen & & 8.0
\end{tabular}

condition. There were some localized areas where the surface texture appeared to contain only coarse aggregate (Photo 5), which was probably caused by a construction deficiency. Considerable pavement deterioration had occurred in the pavement surface in the areas where F-4 aircraft had parked and taxied. Channelized depressions in the tar-rubber were noted at almost every aircraft parking spot. The depressions ranged in depth from $3 / 8$ to $1-1 / 8$ in. (Photos 6 and 7 ) and were as much as 3 to $5 \mathrm{ft}$ in length, and the width of the depressions approximated the tire contact width of the F-4 tire. Aggregate was eroding from the surface in the depressions, which appeared to be saturated with a combination of hydraulic fluid, jet fuel, and lubrication oil. Ruts up to 1 in. deep were noted in the taxiway area of the apron (Photo 8). Longitudinal cracking, which appeared to be caused by overloads, was occurring in the taxiway (Photo 9). The pavement outside of the area used by aircraft was in fairly good condition.

\section{Hurlburt AFB, Florida}

10. Tar-rubber pavements were placed at Hurlburt AFB in 1969. A 4-in. thickness of asphaltic concrete pavement was removed from the limerock base course and replaced with a 2-in. tar binder course and a 2-in. tar-rubber surface course. The approved job-mix formula for the tar-rubber surface course was as follows: 


\begin{tabular}{lcc}
$\begin{array}{c}\text { Sieve } \\
\text { Size }\end{array}$ & $\begin{array}{c}\text { Specified } \\
\text { Limits }\end{array}$ & $\begin{array}{c}\text { Job-Mix } \\
\text { Formula }\end{array}$ \\
\cline { 2 - 2 } $3 / 4$ in. & 100 & 100 \\
1/2 in. & $82-96$ & 93.5 \\
$3 / 8$ in. & $75-80$ & 87.3 \\
No. 4 & $60-73$ & 66.5 \\
No. 8 & $46-60$ & 48.5 \\
No. 16 & $34-48$ & 36.5 \\
No. 30 & $24-38$ & 27.5 \\
No. 50 & $16-28$ & 18.8 \\
No. 100 & $8-18$ & 9.2 \\
No. 200 & $3-6$ & 5.6 \\
Percent bitumen & & 5.4
\end{tabular}

The tar-rubber blend was furnished by the Koppers Company and blended at their plant in Garwood, New Jersey. For compaction after laydown, a tandem (8- to 12-ton) roller was used for breakdown and final rolling, and a 20-ton rubber-tired roller was used for intermediate rolling. 11. The tar-rubber pavements had been used by A-6 aircraft and were in very good condition. Some fuel stains from gasoline spillage were noted, with no apparent distress on the pavement. A minor amount of shrinkage cracking was evident, with the cracks extending down into the surface about $1 / 2$ in.

\section{Pope AFB, North Carolina}

12. The tar-rubber pavements at Pope AFB were constructed on a transient parking apron during the period 1968-69. The pavement structure on apron A consisted of a 2-in. tar-rubber surface course over an existing 1-1/2-in. asphaltic concrete course on a 6-in. PCC pavement. The asphaltic concrete had been placed over the concrete in 1964. Apron B-l consisted of a 2-in. tar-rubber surface course placed directly on the 6-in. PCC. The approved job-mix formula for the tarrubber surface course was as tabulated on the following page. The tarrubber blend was furnished by the Koppers Company and blended at their plant in Garwood, New Jersey. For compaction, a 10-ton tandem roller was used for breakdown and final rolling, and heavy (25-ton) and light 


\begin{tabular}{|c|c|c|}
\hline \multirow[b]{2}{*}{$\begin{array}{l}\text { Sieve } \\
\text { Size } \\
\end{array}$} & \\
\hline & $\begin{array}{l}\text { Specified } \\
\text { Limits } \\
\end{array}$ & $\begin{array}{l}\text { Job-Mix } \\
\text { Formula }\end{array}$ \\
\hline $3 / 4$ in. & 100 & 100 \\
\hline 1/2 in. & $82-96$ & 89.0 \\
\hline 3/8 in. & $75-90$ & 82.5 \\
\hline No. 4 & $60-73$ & 66.5 \\
\hline No. 8 & $46-60$ & 53.0 \\
\hline No. 16 & $34-48$ & 41.0 \\
\hline No. 30 & $24-38$ & 31.0 \\
\hline No. 50 & $16-28$ & 22.0 \\
\hline No. 100 & $8-18$ & 13.0 \\
\hline No. 200 & $3-6$ & 4.5 \\
\hline Percent & & 6.8 \\
\hline
\end{tabular}

(9-ton) rubber-tired rollers were used for intermediate rolling.

13. This transient apron had been used mostly as a loading and unloading ramp for C-130 aircraft, but C-5A aircraft had also used the area. A portion of the apron designated apron B-l had been treated with a tar slurry, and the pavement condition was generally good. Reflection cracking was the only defect noted. There was no evidence of fuel spillage stains. The portions of the apron designated aprons $A$ and $A-1$ had not been sealed and appeared in slightly worse condition than apron B-1. This area had been used as an overflow parking area. There was evidence of some fuel spillage that had caused minor surface deterioration. The reflection cracks were raveling from brittleness. The application of the tar slurry appeared to have benefited the reflection cracks and prevented further raveling.

\section{Selfridge AFB, Michigan}

14. The tar-rubber pavements at Selfridge AFB were constructed during the years 1964 and 1971. In 1964, a 1-in. tar binder course and a l-in. tar-rubber surface course were placed over existing PCC on the east apron. The approved job-mix formula was as tabulated on the following page. The tar-rubber blend was furnished by the Barrett Division, Allied Chemical Corporation. Some of the material was furnished from their New Jersey plant and some from the plant at Bugge Island, 
Sieve

Size

$1 / 2$ in.

$3 / 8$ in.

No. 4

No. 10

No. 20

No. 40

No. 80

No. 200
Specified

Limits

100

86-97

67-82

52-66

36-50

26-39

13-25

4-7

Percent Passing

Percent bitumen

Detroit, Michigan. Compaction was accomplished with 14-ton tandem, 10-ton tandem, and 10-ton rubber-tired rollers.

15. In 1971, a 2-in.-thick tar-rubber surface was placed on a portion of the Air Defense Command parking apron. This was an overlay on an existing PCC. The approved job-mix formula was as follows:

\begin{tabular}{lcc} 
& \multicolumn{2}{c}{ Percent } \\
\cline { 2 - 3 } Sieve & $\begin{array}{c}\text { Specified } \\
\text { Limits }\end{array}$ & $\begin{array}{c}\text { Job-Mix } \\
\text { Formula }\end{array}$ \\
1/2 in. & 100 & 100 \\
3/8 in. & $75-90$ & 86 \\
No. 4 & $60-73$ & 69 \\
No. 8 & $46-60$ & 49 \\
No. 16 & $34-48$ & 41 \\
No. 30 & $24-38$ & 34 \\
No. 50 & $16-28$ & 24 \\
No. 100 & $8-18$ & 11 \\
No. 200 & $3-6$ & 5 \\
Percent bitumen & & 6.4
\end{tabular}

The source of the tar-rubber blend was the same as that for the 1964 construction. Compaction of the pavement was reported to have been accomplished with 10- to 12-ton tandem rollers and a 50-ton rubbertired roller having a tire pressure of 75 psi.

16. The east apron, which had been constructed in 1964, was being used by F-106 and F-100 fighter aircraft. The pavement had been treated with a tar slurry, and the aircraft tires were leaving imprints in the slurry surface (Photo 10). Some reflection cracks had been 
sealed with joint-sealer material. Numerous shrinkage cracks were noted in the surface (Photo 11 ), and the slurry seal had deteriorated in aircraft parking areas (Photo 12). Joints of the underlying PCC had reflected at the surface, and some joints were spalling badly in the tar-rubber and in the underlying concrete (Photo 13). The pavements on this apron area were considered to be in poor condition. Pavements on the part of the east apron constructed in 1971 had not received much usage and were generally in good condition, with limited deterioration beginning to occur from use by F-106 aircraft. Minor deterioration was noted in some areas from the effect of hydraulic fluid spillage (Photo 14), construction joints were showing signs of opening (Photo 15), and reflection cracks from underlying concrete were in need of sealing (Photo 16). Photo 17 shows the condition of the two pavements (1964 and 1971) where they abut one another.

\section{Forbes AF'B, Kansas}

17. The tar-rubber pavements at Forbes AFB were constructed during four separate periods, 1969, 1971, 1972, and 1973. All tar-rubber pavements were overlays on deteriorated PCC pavements and consisted of a 1-1/2-in. tar-rubber surface course and a 1-1/2-in. tar binder course. The 1971 overlay was placed on concrete that contained a considerable amount of " $D$ " cracking and a larger number of spalls. The approved jobmix formula for the tar-rubber surface course constructed in 1969 was as follows:

\begin{tabular}{l}
$\begin{array}{l}\text { Sieve } \\
\text { Size }\end{array}$ \\
\hline $1 / 2$ in. \\
$3 / 8$ in. \\
No. 4 \\
No. 8 \\
No. 16 \\
No. 30 \\
No. 50 \\
No. 100 \\
No. 200
\end{tabular}

Percent bitumen

\begin{tabular}{cc}
\multicolumn{2}{c}{ Percent Passing } \\
\hline Specified & Job-Mix \\
Limits & Formula \\
\cline { 2 - 2 } 100 & 100 \\
$79-94$ & 96 \\
$59-73$ & 64 \\
$46-60$ & 54 \\
$34-48$ & 40 \\
$24-38$ & 28 \\
$16-28$ & 20 \\
$8-18$ & 11 \\
$3-6$ & 5.8 \\
&
\end{tabular}

6.1 
The tar-rubber binder was furnished by the Koppers Company and blended by the Reilly Tar Company plant in East St. Louis, Illinois.

18. The approved job-mix formula for the 1971, 1972, and 1973 tar-rubber surface courses was as follows:

$\begin{array}{lcc}\begin{array}{l}\text { Sieve } \\ \text { Size }\end{array} & \begin{array}{c}\text { Specified } \\ \text { Limits }\end{array} & \begin{array}{c}\text { Job-Mix } \\ \text { Formula }\end{array} \\ \text { 1/2 in. } & 100 & 100 \\ 3 / 8 \text { in. } & 79-94 & 93 \\ \text { No. } 4 & 59-73 & 64 \\ \text { No. } 8 & 46-60 & 54 \\ \text { No. } 16 & 34-48 & 38 \\ \text { No. 30 } & 24-38 & 27 \\ \text { No. } 50 & 16-28 & 20 \\ \text { No. 100 } & 8-18 & 11 \\ \text { No. 200 } & 3-6 & 5.0 \\ \text { Percent bitumen } & & 7.8\end{array}$

The tar-rubber blend was furnished by the Koppers Company and blended in Chicago, Illinois. Compaction requirements for the four construction projects consisted of the use of three-wheel breakdown rollers, a 25-ton rubber-tired roller, and a 12-ton tandem roller for final rolling. It was reported that a vibratory roller was used for compaction of the pavements in 1972; however, characteristics of the roller, such as weight, vibrating frequency, etc., were not obtained.

19. The parking aprons surfaced with tar-rubber had been used by C-130, C-135, and transient-type aircraft. The pavements were receiving very little usage at the time of this investigation. The pavements constructed in 1969 were located in a refueling area on the south apron. They had been sealed with a tar seal and a tar-slurry seal in 1972 (Photo 18). The seal coat had deteriorated on the surface where fuel had spilled (Photo 19). Minor random and reflection cracking was noted in this area. The 1971 pavements, which were used by C-130 aircraft from 1971 to 1974, contained reflection and shrinkage cracks (Photo 20). The 1972 pavements on the northwest apron contained reflection cracks, and, in some areas, water was seeping out of the cracks (Photo 2l). The construction joints were not well sealed (Photo 22), and cores obtained 
in the center of the paving lane indicated a high percentage of voids (Photo 23). The 1973 pavements were in good condition, with a good surface texture (Photo 24) and apparently good construction joints (Photo 25), though some hairline reflection cracks were noted on the surface.

\section{Mountain Home AFB, Idaho}

20. The tar-rubber pavements at Mountain Home AFB were constructed during 1968 and 1970. The 1968 pavements were 40- by 510-ft strips that had been cut out and placed on the operational maintenance apron. The asphaltic concrete overlay on the apron was notched out to the underlying PCC and replaced with a 2-1/2-in. tar-concrete binder course and a 1-l/2-in. tar-rubber course. A 40-1b roofing felt was used as a bond breaker between the binder course and the concrete on two of the strips; however, use of the felt was discontinued when desired density could not be obtained due to the mix shoving on the felt. The 1970 construction consisted of placing two 44- by 800-ft strips (strips C and F) on the southeastern portion of the apron, using the same type construction as that in 1968. The approved job-mix formula for both the 1968 and 1970 construction was as follows:

$\begin{array}{lc}\begin{array}{l}\text { Sieve } \\ \text { Size }\end{array} & \begin{array}{c}\text { Specified } \\ \text { Limits }\end{array} \\ 3 / 4 \text { in. } & 100 \\ \text { 1/2 in. } & 82-96 \\ 3 / 8 \text { in. } & 75-90 \\ \text { No. } 4 & 60-73 \\ \text { No. } 8 & 46-60 \\ \text { No. } 16 & 34-48 \\ \text { No. } 30 & 24-38 \\ \text { No. } 50 & 16-28 \\ \text { No. 100 } & 8-18 \\ \text { No. } 200 & 3-6\end{array}$

Percent bitumen

\begin{tabular}{|c|c|}
\hline \multicolumn{2}{|c|}{ Percent Passing } \\
\hline $\begin{array}{l}\text { Specified } \\
\text { Limits }\end{array}$ & $\begin{array}{l}\text { Job-Mix } \\
\text { Formula }\end{array}$ \\
\hline $\begin{array}{c}100 \\
82-96 \\
75-90 \\
60-73 \\
46-60 \\
34-48 \\
24-38 \\
16-28 \\
8-18 \\
3-6\end{array}$ & $\begin{array}{r}100 \\
88.4 \\
80.6 \\
65.3 \\
54.2 \\
45.4 \\
32.2 \\
19.7 \\
10.6 \\
4.8\end{array}$ \\
\hline & 9.1 \\
\hline
\end{tabular}

The tar-rubber blend was furnished by the Koppers Company and blended in their plant in Fontana, California. For compaction after laydown of the 
tar-rubber pavement, 8- to 12-ton tandem steel-wheel rollers were used for breakdown and final rolling, and a 20-ton rubber-tired roller was used for intermediate rolling. The weight of the rubber-tired roller was later increased to 25 tons since the densities obtained were only about 95 percent instead of the 98 percent required.

21. The pavements constructed in 1968 were not being used by aircraft at the time of this investigation, but they had been used as a parking area for $\mathrm{F}-4$ aircraft. Two or three seal coats had been applied to the surface, but fuel spillage had deteriorated the seal in aircraft parking areas (Photo 26). Several areas where F-4 aircraft had been parked had been depressed and damaged; therefore, they had been removed and replaced with PCC (Photo 27) in 1971. Roofing felt had been used in two strips as a bond breaker between the PCC and the tar binder for protection against reflection cracks. However, during construction, the felt had moved under rolling and prevented proper compaction and thus had not prevented reflection cracking from appearing at the surface (Photo 28). The 1970 tar-rubber pavements had not received a seal coat (Photo 29), and considerable reflection cracking and open construction joints in need of sealing were noted (Photo 30). Lack of compaction at the joints during construction was quite evident.

\section{Langley AFB, Virginia}

22. The tar-rubber pavements at Langley AFB were constructed on the west ramp in 1966, the north ramp in 1969, and the east ramp in 1971. Pavement structures of the three areas were as follows: east ramp, 2 in. of tar-rubber over 10 in. of PCC over 6 in. of PCC; north ramp, 2 in. of tar-rubber over 6 in. of PCC; and west ramp, 2 in. of tarrubber over 10-1/2 in. of PCC. The approved job-mix formulas were as tabulated on the following page. The rubber for the 1966, 1969, and 1971 constructions was furnished by the Goodyear Tire and Rubber Company, and the base tar was supplied by the Baltimore Tar Company, Maryland. The materials were blended at the plant on the jobsite. Compaction was accomplished with 10- to 12-ton tandem steel-wheel rollers and 50-ton rubber-tired rollers. 
1966 and 1969 Constructions

\begin{tabular}{|c|c|c|}
\hline $\begin{array}{l}\text { Sieve } \\
\text { Size }\end{array}$ & $\begin{array}{l}\text { Specified } \\
\text { Limits } \\
\end{array}$ & $\begin{array}{l}\text { Job-Mix } \\
\text { Formula }\end{array}$ \\
\hline $\begin{array}{l}1 / 2 \text { in. } \\
3 / 8 \text { in. } \\
\text { No. } 4 \\
\text { No. } 10 \\
\text { No. } 20 \\
\text { No. } 40 \\
\text { No. } 80 \\
\text { No. } 200\end{array}$ & $\begin{array}{c}100 \\
79-94 \\
59-73 \\
43-57 \\
29-43 \\
20-33 \\
10-20 \\
3-6\end{array}$ & $\begin{array}{r}100 \\
98.0 \\
72.0 \\
49.0 \\
31.0 \\
20.0 \\
10.0 \\
6.0\end{array}$ \\
\hline \multicolumn{2}{|c|}{ Percent bitumen } & 8.0 \\
\hline
\end{tabular}

1971 Construction

$\begin{array}{lcc}\begin{array}{c}\text { Sieve } \\ \text { Size }\end{array} & \begin{array}{c}\text { Specified } \\ \text { Limits }\end{array} & \begin{array}{c}\text { Job-Mix } \\ \text { Formula }\end{array} \\ 3 / 4 \text { in. } & 100 & 100 \\ \text { 1/2 in. } & 82-96 & 93 \\ 3 / 8 \text { in. } & 75-90 & 85 \\ \text { No. } 4 & 60-73 & 72 \\ \text { No. } 8 & 46-60 & 54 \\ \text { No. 16 } & 34-48 & 38 \\ \text { No. 30 } & 24-38 & 26 \\ \text { No. 50 } & 16-28 & 16 \\ \text { No. 100 } & 8-18 & 10 \\ \text { No. 200 } & 3-6 & 6 \\ \text { Percent bitumen } & & 8.1\end{array}$

23. The west ramp was divided into two main parking areas, one for C-130 aircraft and the other for F-106 and T-33 aircraft. At the time of this investigation, the pavement in the C-130 area was in good condition, whereas the other area was in poor condition. The C-130 area had developed some cracking, and fuel spillage was beginning to cause raveling in the surface (Photo 31). However, the cracking in the fighter area was more severe, and rutting, raveling, and general deterioration were occurring in the inmediate parking area (Photo 32). Most of the damaged parking areas had been removed and replaced with PCC in 1971. The 1969 pavements on the north ramp, which had been used for parking light aircraft, 
were in good condition, but construction joints were beginning to open and some reflection cracking was evident (Photo 33). The east ramp, constructed in 1971, was divided into three parking areas: one for C-135 aircraft, one for $\mathrm{C}-118$ and T-29 aircraft, and one for T-39 aircraft. During construction, an open surface texture had resulted in some of the apron area due to pulling and tearing of the surface during laydown operations (Photo 34). All three areas were generally in good condition. The parking area for $\mathrm{C}-118$ and $\mathrm{T}-29$ aircraft showed the worst stains from excessive fuel spillage (Photo 35), and some of the fines were beginning to ravel from the surface in that area.

\section{Wright-Patterson AFB, Ohio}

24. The tar-rubber pavements at Wright-Patterson AFB were constructed during the years 1960, 1962-63, 1966, 1970, and 1972. The 1960 pavements were constructed on taxiways 8 and 12. A 1-in. tar-rubber surface course and a 1-1/2-in. tar binder course were placed on the 7-in. PCC on taxiway 8 and the 9-in. PCC on taxiway 12. In 1962-63, 1-in. tarrubber and 1-1/2-in. tar binder courses were placed on the 10-in. PCC on ramp $I$, and 1-in. tar-rubber and 1-1/2-in. tar binder courses were placed on the 11-in. PCC on ramp D. In 1966, 1-in. tar-rubber and 1-1/2-in. tar binder courses were placed on the 10-in. PCC on ramp J. In 1970, the 25-in.-thick PCC warmup apron was overlaid with 1-in. tarrubber and 1-1/2-in. tar binder courses. In 1972, pavements were placed on the touchdown end of the runway. Information on mix design and jobmix formulas for the work at Wright-Patterson was not available. The tar-rubber blend for the various projects was furnished by the Koppers Company.

25. The pavements constructed in $\mathbf{1 9 6 0}$ were located on pavements identified at the time of this investigation as taxiways 8 and 12. The outer edges of taxiway 8 had been used for parking aircraft, mainly the $\mathrm{F}-4, \mathrm{~F}-5$, and $\mathrm{T}-38$. The pavement in the immediate parking area was in poor condition, with deterioration in the surface from fuel spillage and high tire pressures (Photo 36). Pavements in taxiway 12 had not been 
used for parking and were in good condition. This pavement had been treated with Koppers BPR rejuvenator. The 1962-63 pavements on ramps D and I had both been treated twice with a tar slurry. The pavement on ramp I, which had been exposed only to limited aircraft use, was in good condition, with mostly only reflection cracking, which had been sealed in 1970. Ramp D, which had been used for parking T-33 and T-39 aircraft, showed deterioration in immediate parking areas from fuel and hydraulic fluid spillage (Photo 37). Often, an excessive amount of fuel had been spilled (Photo 38), and this poor housekeeping habit had caused general deterioration where cracks occurred (Photo 39). The pavement on ramp J, constructed in 1966, had been treated with a tar slurry in 1970. Reflection cracking and deterioration from fuel or hydraulic fluid spillage were occurring in a few areas where aircraft had parked (Photo 40). The warmup apron constructed in 1970 had been used by.all types of aircraft and was generally in poor condition due to poor construction. Tearing of the surface and raveling of the open construction joints were noted (Photo 41). There was no evidence of rutting or fuel spillage in this area. The 1972 pavements on the end of the runway were in good condition.

\section{Rickenbacker AFB, Ohio}

26. Tar-rubber pavements were constructed at Rickenbacker AFB in 1963, 1966, 1968, and 1973. The 1963 construction, on the northeast parking aprons (area 9), consisted of 1-1/4-in. tar-rubber and 1-1/2-in. tar binder courses over 17-in. PCC. The 1966 construction, on the main parking aprons (area 4), consisted of 1-in. tar-rubber and 1-in. tar binder courses over 12-in. PCC. The 1968 construction, on the northeast parking apron and the southwest apron, consisted of a 1-in. tar-rubber surface course and a 2-in. tar binder course over 12-in. PCC. The 1973 construction, on the southwest apron extension, consisted of a l-in. tar-rubber surface course and a 2-in. tar binder course over 17-in. PCC. Information on mix-design formulas for the work at Rickenbacker was not available. 
27. The 1963 pavements (area 9) had been used for parking F-101 and tanker aircraft and were generally in good condition. Joints had been sealed, and there was no evidence of any significant fuel spillage. The 1966 pavements had been used for parking C-123 aircraft and refueling pits had also been located in this area (area 4). Pavements in the refueling pit area were in poor condition, while those outside the refueling area were in good condition. Pavements on the southwest apron, constructed in 1968, had been used for parking $\mathrm{KC}-135$ and $\mathrm{C}-123$ aircraft. Reflection cracks had been sealed, and there were no stains from excessive fuel spillage. These pavements were generally in good condition. The southwest apron extension pavements, constructed in 1973, had been used for parking KC-97 aircraft. These pavements were also in good condition, with some fuel spillage stains and a minor amount of reflection cracking. 
28. As stated previously, the core samples of the tar-rubber pavements obtained at each airfield were subjected to laboratory testing. The tar-rubber surface course was separated from the binder course, and density was determined. It was not possible to obtain a sample from the paving joints, as the cores broke either when separated from the binder course or in coring operations. The densities obtained on each core are presented in Table 1. Considerable difficulty was experienced in trying to extract the tar-rubber binder from the aggregate so that gradations of aggregate and binder content could be determined. A technique was finally developed in which the sample was soaked in quinoline at room temperature for approximately $12 \mathrm{hr}$ and agitated prior to being placed in an extractor. After all the binder that could be washed out was removed, the aggregate was then placed in a furnace (about $1000^{\circ} \mathrm{F}$ ) for approximately $2 \mathrm{hr}$ to insure that all binder was burned from the aggregate. It was not possible to recover the tar-rubber binder since the boiling point of quinoline is above $300^{\circ} \mathrm{F}$ and the tar-rubber binder material could not be separated without causing damage to the binder material. Aggregate gradations for all samples tested are shown in Plates 1-10. The field samples obtained in areas that were subjected to fuel, oil, and hydraulic fluid spillage were tested for density and stability. Results of these tests are shown in Table 1. To determine effects of jet fuel and hydraulic fluid on tar-rubber, a series of samples were soaked in the laboratory for a period of $48 \mathrm{hr}$ and then tested for stability. Results of these tests are also shown in Table 1. Another series of cores were soaked in jet fuel and hydraulic fluid for aperiod of 5 days and then allowed to drain for a period of 5 days prior to measurement of density and stability. Results of these tests are shown in Table 2 and Plate 11.

\section{Materials}

29. As noted in Plates 1-10, the aggregates used in the tarrubber mixtures essentially met the gradation requirements set forth in 
Corps of Engineers Guide Specification CE-807.25.* In some cases, the material plotted on the fine side of the specification limits (hatched area). This development could possibly be attributed to the degradation of the aggregate in the sampling and the use of a high-temperature furnace.

\section{Compaction}

30. Construction control data were available for work performed at five of the airfields. The tabulation below shows the percent of the laboratory density (98 percent was required) that was reported during construction. Also included in this tabulation are the results of the survey tests performed in 1974 .

\begin{tabular}{|c|c|c|c|c|}
\hline Airfield & $\begin{array}{c}\text { Year } \\
\text { Constructed } \\
\end{array}$ & \multicolumn{2}{|c|}{$\begin{array}{c}\text { Construction } \\
\text { Control Data } \\
\text { Average \% } \\
\text { Density }\end{array}$} & $\begin{array}{c}1974 \\
\text { Survey Data } \\
\text { Average \% } \\
\text { Density } \\
\end{array}$ \\
\hline Forbes & 1972 & 94.3 & 95.4 & 95.8 \\
\hline Langley & 1966 & 95.7 & 99.3 & 100.3 \\
\hline MacDill & 1971 & 96.5 & 97.9 & 97.7 \\
\hline Forbes & 1971 & 93.4 & 95.4 & 93.9 \\
\hline Mountain Home & 1968 & 94.8 & 96.0 & 98.6 \\
\hline
\end{tabular}

As can be noted above, the densities obtained in the joints during construction were quite low, and some of those obtained in the paving lane were below the 98 percent required. The 98 percent required density was obtained at Langley, where 50-ton rubber-tired rollers were used during construction, and at MacDill, where 25-ton rollers were used. However, as noted in Table 1 and Plate 12, a considerable range of densities was obtained. Even though the average density at MacDill was approximately 98 percent, the density spread was quite wide and ranged to as low as 93 percent. Lack of compaction during construction appears to be one

* Headquarters, Department of the Army, "Rubberized-Tar Concrete Pavements for Airfields and Heliports (Central-Plant Hot-Mix)," Guide Specification CE-807.25, Feb 1971, Washington, D. C. 
of the major causes of the poor performance observed in the tar-rubber pavements. It should be pointed out that none of the densities indicated in Table 1 or Plate 12 were taken at a joint, as it was not possible to obtain a sample from the joints that were cored; the core samples would not stay together as a result of lack of compaction. Poor compaction resulted in joints opening and raveling. The variation in density is also indicated in the range of voids shown in Table 1 and Plate 13. Mix-design formulas based on specified 3 to 5 percent voids (total mix) and 98 percent density could possibly result in a range of voids from about 3 to 6 percent. Prior studies conducted on tar-rubber pavements indicated that the specified void content should not exceed 6 percent, as serious seepage of spilled fuel into the pavement will occur when void contents exceed this value.

\section{Effects of JP -4 and Hydraulic Fluid}

31. A comparison of the densities of the cores obtained in spillage areas with those in nonspillage areas (Table 1 ) indicates that there is no apparent effect on the densities as a result of the spillage. The possibility of a volume change occurring from the action of the fuel and a swelling of the material with a decrease in density was investigated, but there was no evidence of this happening. Core samples were soaked for $48 \mathrm{hr}$ in $\mathrm{JP}-4$ and hydraulic fluid and then measured for stability. Results are shown in Table 1. Nineteen of the 23 samples soaked in hydraulic fluid indicated higher stability values than those obtained on similar samples soaked in JP-4. There was no apparent trend of pavement age affecting the ability to resist effects of $\mathrm{JP}-4$ or hydraulic fluid. A series of samples from Selfridge AFB, Forbes AFB, and Wright-Patterson AFB were soaked in JP-4 and hydraulic fluid for a period of 5 days and then allowed to drain for a period of 5 days. The average stability values measured for the samples subjected to hydraulic fluid were higher in all cases than those for the samples subjected to JP-4 (Table 2). The effects on density are shown in Plate 1l. The samples soaked in hydraulic fluid all had densities higher than those of the original sample, 
and the ones soaked in JP-4 indicated very little change from the original. This indicates that the $\mathrm{JP}-4$ will evaporate from the pavement, whereas the hydraulic fluid will tend to remain in the pavement for a longer period of time. 
32. The following statements summarize the results of this investigation:

a. The performance of the tar-rubber pavements is dependent upon the quality of construction and subsequent usage of the pavement. Pavements at Langley AFB, where good construction density was obtained, performed satisfactorily for a period of about 5 years under usage of highpressure tires and repeated jet fuel spillage. Pavements at MacDill AFB, where the overall average construction density was acceptable but indicated a wide range in densities, failed after a usage of about 2 years.

b. Spillage of JP-4 fuel on tar-rubber pavements is more detrimental than spillage of hydraulic fluid on a short-term basis. Over a long period of time, the ability of the hydraulic fluid to remain in the pavement may make this fluid the more detrimental of the two.

c. The stability values of tar-rubber pavements have very little meaning since the pavements become brittle very quickly and high stability values result. There is no clear relationship between stability and age.

d. Use of heavy rubber-tired rollers appears to be necessary during construction in order to meet the requirement of 98 percent density. Vibratory rollers were used for the 1972 construction at Forbes AFB, and very low densities were obtained. Rollers were operated at only one vibration frequency for this work.

e. Tar-rubber pavements perform poorly in all areas adjacent to refueling pits. Poorly constructed pavements fail rapidly.

33. The following recommendations are considered warranted based on the results of this investigation:

a. Very strict quality control should be enforced during construction for all tar-rubber pavement projects. Special effort should be made to obtain desired density and uniformity of appearance in joint construction.

b. Tar-rubber pavements should not be placed in refueling pit areas. PCC should be used.

c. Prior to overlay of PCC pavements, all defects in PCC pavements should be repaired so that the defects do not reflect and affect the overlay. 
d. Tar-rubber pavements should not be used in aircraft parking areas if the tire contact area is less than $100 \mathrm{sq}$ in. and the tire pressure is greater than 250 psi.

e. Better housekeeping rules, such as use of drip pans, hosing off excess spillage, etc., should be enforced to minimize deterioration from fuel spillage.

f. Intermediate rolling with rubber-tired rollers loaded to at least 25 tons is essential if the desired densities in the tar-rubber pavements are to be obtained. Similar results should be possible with high-frequency (1500 vibrations per minute or more) vibratory rollers which can produce an equivalent or greater total compactive effort. 
Table 1

Results of Laboratory Tests of Bitumen Content, Percent Voids, Unit Weight, Stability, and Flow

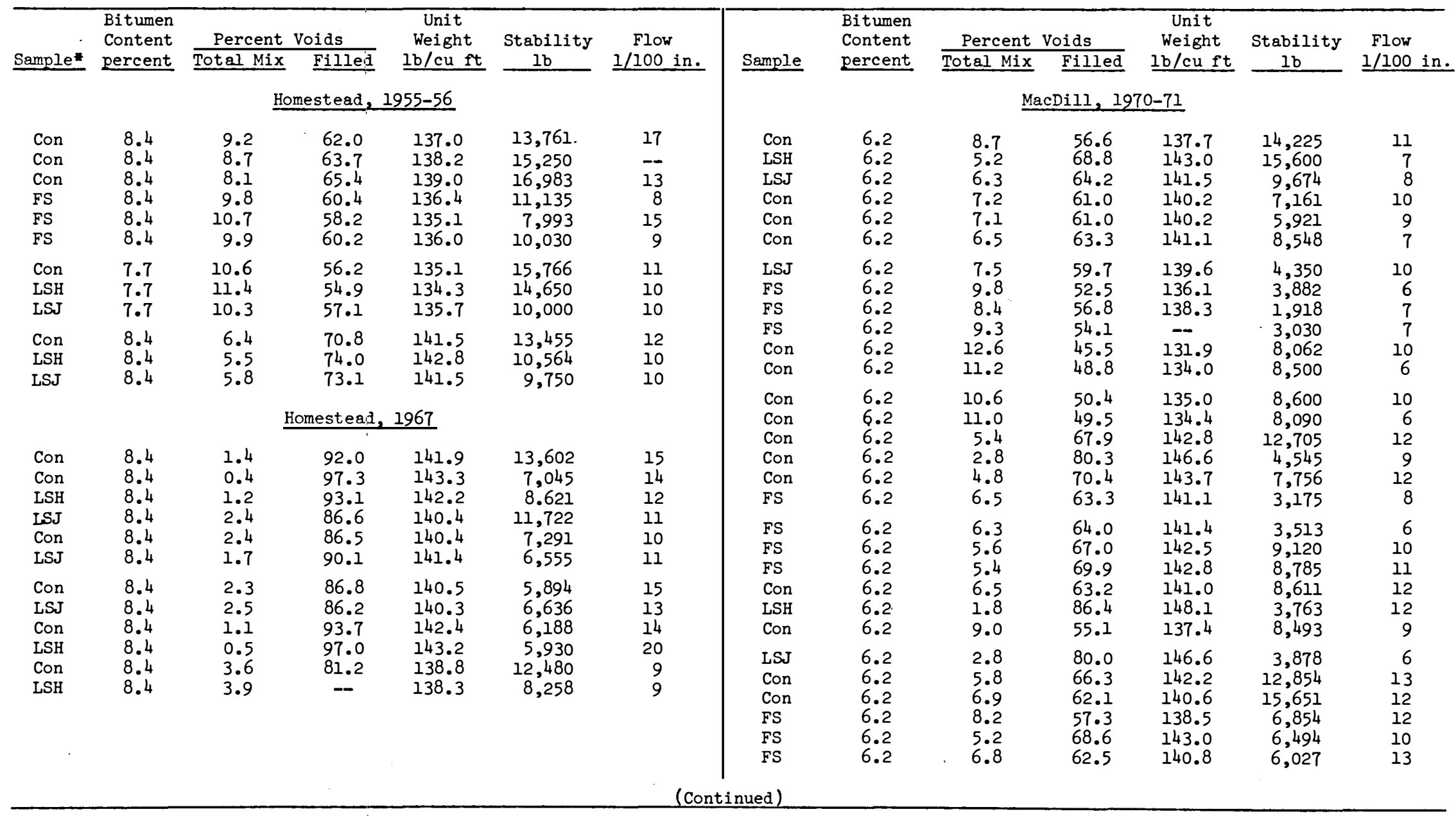

* Con - Control sample.

FS - Field core from fuel spillage area.

LSH - Core soaked for $48 \mathrm{hr}$ in hydraulic fluid in laboratory.

LSJ - Core soaked for $48 \mathrm{hr}$ in JP-4 in laboratory. 
Table 1 (Continued)

\begin{tabular}{|c|c|c|c|c|c|c|c|c|c|c|c|c|c|}
\hline Sample & $\begin{array}{l}\text { Bitumen } \\
\text { Content } \\
\text { percent }\end{array}$ & $\frac{\text { Percent }}{\text { Total Mix }}$ & $\begin{array}{l}\text { Voids } \\
\text { Filled }\end{array}$ & $\begin{array}{c}\text { Unit } \\
\text { Weight } \\
\text { lb/cu ft } \\
\end{array}$ & \multirow[t]{2}{*}{$\begin{array}{c}\text { Stability } \\
\mathrm{lb}\end{array}$} & \multirow[t]{2}{*}{$\begin{array}{c}\text { Flow } \\
1 / 100 \text { in. }\end{array}$} & \multirow[t]{2}{*}{ Sample } & \multirow[t]{2}{*}{$\begin{array}{l}\text { Bitumen } \\
\text { Content } \\
\text { percent }\end{array}$} & \multicolumn{2}{|c|}{$\begin{array}{l}\text { Percent Voids } \\
\text { Total Mix Filled }\end{array}$} & \multirow{2}{*}{$\begin{array}{c}\text { Unit } \\
\text { Weight } \\
\text { Ib/cu ft } \\
\text { inued) }\end{array}$} & \multirow[t]{2}{*}{$\begin{array}{l}\text { Stability } \\
1 \mathrm{~b}\end{array}$} & \multirow[t]{2}{*}{$\begin{array}{l}\text { Flow } \\
1 / 100 \text { in }\end{array}$} \\
\hline \multicolumn{5}{|c|}{ MacDill, 1970-71. (Continued) } & & & & & \multicolumn{2}{|c|}{ Pope, 1968-69 (Continued) } & & & \\
\hline $\begin{array}{l}\text { Con } \\
\text { Con } \\
\text { FS } \\
\text { FS } \\
\text { Con } \\
\text { LSJ }\end{array}$ & $\begin{array}{l}6.2 \\
6.2 \\
6.2 \\
6.2 \\
6.2 \\
6.2\end{array}$ & $\begin{array}{l}6.1 \\
6.4 \\
7.1 \\
7.4 \\
4.7 \\
4.3\end{array}$ & $\begin{array}{l}64.9 \\
63.7 \\
61.2 \\
60.1 \\
71.1 \\
73.1\end{array}$ & $\begin{array}{l}141.7 \\
141.2 \\
140.2 \\
139.8 \\
143.9 \\
144.5\end{array}$ & $\begin{array}{r}10,481 \\
10,272 \\
8,050 \\
2,725 \\
12,371 \\
9,878\end{array}$ & $\begin{array}{l}18 \\
16 \\
14 \\
13 \\
15 \\
11\end{array}$ & $\begin{array}{l}\text { Con } \\
\text { Con } \\
\text { Con } \\
\text { LSH } \\
\text { LSH } \\
\text { LSH }\end{array}$ & $\begin{array}{l}8.2 \\
8.2 \\
8.2 \\
8.2 \\
8.2 \\
8.2\end{array}$ & $\begin{array}{l}3.5 \\
3.2 \\
3.8 \\
3.6 \\
3.7 \\
4.2\end{array}$ & $\begin{array}{l}81.5 \\
82.6 \\
80.2 \\
81.0 \\
80.6 \\
78.6\end{array}$ & $\begin{array}{l}146.4 \\
145.7 \\
145.9 \\
146.2 \\
146.0 \\
145.3\end{array}$ & $\begin{array}{l}2,160 \\
1,709 \\
1,826 \\
2,467 \\
2,054 \\
2,352\end{array}$ & $\begin{array}{l}18 \\
15 \\
15 \\
14 \\
14 \\
14\end{array}$ \\
\hline $\begin{array}{l}\text { Con } \\
\text { FS } \\
\text { FS } \\
\text { Con } \\
\text { Con } \\
\text { LSJ }\end{array}$ & $\begin{array}{l}6.2 \\
6.2 \\
6.2 \\
6.2 \\
6.2 \\
6.2\end{array}$ & $\begin{array}{l}6.9 \\
7.4 \\
6.8 \\
4.8 \\
2.6 \\
2.5\end{array}$ & $\begin{array}{l}62.5 \\
60.0 \\
62.2 \\
70.7 \\
81.7 \\
82.4\end{array}$ & $\begin{array}{l}140.5 \\
139.7 \\
140.6 \\
143.8 \\
147.0 \\
147.2\end{array}$ & $\begin{array}{r}6,151 \\
5,141 \\
2,666 \\
13,937 \\
7,426 \\
9,786\end{array}$ & $\begin{array}{r}10 \\
8 \\
10 \\
11 \\
17 \\
13\end{array}$ & $\begin{array}{l}\text { Con } \\
\text { Con } \\
\text { Con } \\
\text { LSJ } \\
\text { LSJ } \\
\text { LSJ }\end{array}$ & $\begin{array}{l}6.5 \\
6.5 \\
6.5 \\
6.5 \\
6.5 \\
6.5\end{array}$ & $\begin{array}{l}7.8 \\
7.8 \\
8.2 \\
7.8 \\
7.3 \\
7.2\end{array}$ & $\begin{array}{l}60.4 \\
60.4 \\
58.9 \\
60.7 \\
62.4 \\
62.7\end{array}$ & $\begin{array}{l}141.2 \\
141.3 \\
140.5 \\
141.4 \\
141.9 \\
142.2\end{array}$ & $\begin{array}{l}6,725 \\
5,863 \\
6,450 \\
3,859 \\
4,300 \\
3,848\end{array}$ & $\begin{array}{l}15 \\
12 \\
14 \\
13 \\
14 \\
15\end{array}$ \\
\hline $\begin{array}{l}\text { Con } \\
\text { LSH } \\
\text { Con } \\
\text { FS } \\
\text { FS }\end{array}$ & $\begin{array}{l}6.2 \\
6.2 \\
6.2 \\
6.2 \\
6.2\end{array}$ & $\begin{array}{l}2.5 \\
4.5 \\
8.1 \\
8.9 \\
5.8\end{array}$ & $\begin{array}{l}82.3 \\
71.7 \\
57.7 \\
55.4 \\
66.0\end{array}$ & $\begin{array}{l}147.1 \\
144.1 \\
139.0 \\
137.6 \\
142.1\end{array}$ & $\begin{array}{r}10,717 \\
13,052 \\
9,216 \\
7,798 \\
8,971\end{array}$ & $\begin{array}{l}15 \\
12 \\
11 \\
10 \\
13\end{array}$ & $\begin{array}{l}\text { Con } \\
\text { Con } \\
\text { Con } \\
\text { LSH } \\
\text { LSH } \\
\text { LSH }\end{array}$ & $\begin{array}{l}6.5 \\
6.5 \\
6.5 \\
6.5 \\
6.5 \\
6.5\end{array}$ & $\begin{array}{l}8.9 \\
7.5 \\
8.5 \\
8.5 \\
8.5 \\
8.4\end{array}$ & $\begin{array}{l}57.0 \\
61.4 \\
57.9 \\
58.1 \\
58.1 \\
58.4\end{array}$ & $\begin{array}{l}139.6 \\
141.6 \\
140.0 \\
140.2 \\
140.2 \\
140.3\end{array}$ & $\begin{array}{l}4,858 \\
5,990 \\
5,533 \\
5,127 \\
4,971 \\
4,903\end{array}$ & $\begin{array}{l}13 \\
16 \\
17 \\
12 \\
11 \\
23\end{array}$ \\
\hline $\begin{array}{l}\text { Con } \\
\text { Con } \\
\text { FS } \\
\text { LSH } \\
\text { LSJ }\end{array}$ & $\begin{array}{l}5.5 \\
5.5 \\
5.5 \\
5.5 \\
5.5\end{array}$ & $\begin{array}{l}3.1 \\
4.9 \\
3.2 \\
5.0 \\
4.3\end{array}$ & $\begin{array}{c}\text { Hurlburt, } \\
78.0 \\
69.3 \\
77.6 \\
68.8 \\
71.9\end{array}$ & $\begin{array}{l}154.5 \\
151.8 \\
154.4 \\
151.6 \\
152.7\end{array}$ & $\begin{array}{r}10,078 \\
10,067 \\
8,575 \\
8,882 \\
5,428\end{array}$ & $\begin{array}{l}12 \\
11 \\
12 \\
11 \\
12\end{array}$ & $\begin{array}{l}\text { Con } \\
\text { Con } \\
\text { Con } \\
\text { LSJ } \\
\text { LSJ } \\
\text { LSJ }\end{array}$ & $\begin{array}{l}5.8 \\
5.8 \\
5.8 \\
5.8 \\
5.8 \\
5.8\end{array}$ & $\begin{array}{l}7.8 \\
8.1 \\
-- \\
8.5 \\
8.6 \\
8.5\end{array}$ & $\begin{array}{c}58.1 \\
56.9 \\
-- \\
55.7 \\
55.4 \\
55.6\end{array}$ & $\begin{array}{l}143.6 \\
143.5 \\
142.5 \\
142.9 \\
142.3 \\
142.5\end{array}$ & $\begin{array}{l}5,078 \\
5,595 \\
5,244 \\
4,555 \\
4,056 \\
2,964\end{array}$ & $\begin{array}{l}21 \\
16 \\
17 \\
15 \\
15 \\
14\end{array}$ \\
\hline $\begin{array}{l}\text { Con } \\
\text { LSJ } \\
\text { FS }\end{array}$ & $\begin{array}{l}5.5 \\
5.5 \\
5.5\end{array}$ & $\begin{array}{l}4.9 \\
4.4 \\
4.6\end{array}$ & $\begin{array}{r}70.1 \\
71.7 \\
70.7 \\
\text { Pope, } 19 \\
\end{array}$ & $\begin{array}{l}152.0 \\
152.6 \\
152.3 \\
-69\end{array}$ & $\begin{array}{l}7,475 \\
4,466 \\
2,811\end{array}$ & $\begin{array}{l}15 \\
24 \\
27\end{array}$ & $\begin{array}{l}\text { Con } \\
\text { Con } \\
\text { Con } \\
\text { LSJ } \\
\text { LSJ } \\
\text { LSJ }\end{array}$ & $\begin{array}{r}5.8 \\
5.8 \\
5.8 \\
5.8 \\
5.8 \\
5.8\end{array}$ & $\begin{array}{l}8.0 \\
8.0 \\
8.1 \\
8.0 \\
9.1 \\
8.2\end{array}$ & $\begin{array}{l}57.3 \\
57.3 \\
56.9 \\
57.2 \\
53.9 \\
56.7\end{array}$ & $\begin{array}{l}143.2 \\
143.7 \\
143.0 \\
143.2 \\
141.6 \\
143.0\end{array}$ & $\begin{array}{l}6,063 \\
6,969 \\
6,753 \\
4,835 \\
4,877 \\
5,117\end{array}$ & $\begin{array}{l}19 \\
16 \\
16 \\
17 \\
20 \\
16\end{array}$ \\
\hline $\begin{array}{l}\text { Con } \\
\text { Con } \\
\text { Con } \\
\text { LSJ } \\
\text { LSJ } \\
\text { LSJ }\end{array}$ & $\begin{array}{l}7.7 \\
7.7 \\
7.7 \\
7.7 \\
7.7 \\
7.7\end{array}$ & $\begin{array}{l}4.4 \\
4.3 \\
5.8 \\
4.7 \\
6.9 \\
4.7\end{array}$ & $\begin{array}{l}77.0 \\
77.5 \\
71.4 \\
75.8 \\
67.3 \\
75.4\end{array}$ & $\begin{array}{l}147.8 \\
148.0 \\
145.6 \\
147.3 \\
143.8 \\
147.2\end{array}$ & $\begin{array}{l}2,756 \\
3,360 \\
3,328 \\
2,554 \\
1,164 \\
2,822\end{array}$ & $\begin{array}{l}20 \\
14 \\
15 \\
25 \\
20 \\
17\end{array}$ & $\begin{array}{l}\text { Con } \\
\text { Con }\end{array}$ & $\begin{array}{l}10.6 \\
10.6\end{array}$ & $\begin{array}{l}9.1 \\
8.2\end{array}$ & $\begin{array}{r}68.5 \\
71.1\end{array}$ & $\begin{array}{l}141.3 \\
142.8\end{array}$ & $\begin{array}{l}7,048 \\
6,561\end{array}$ & $\begin{array}{l}18 \\
14\end{array}$ \\
\hline
\end{tabular}


Table I (Continued)

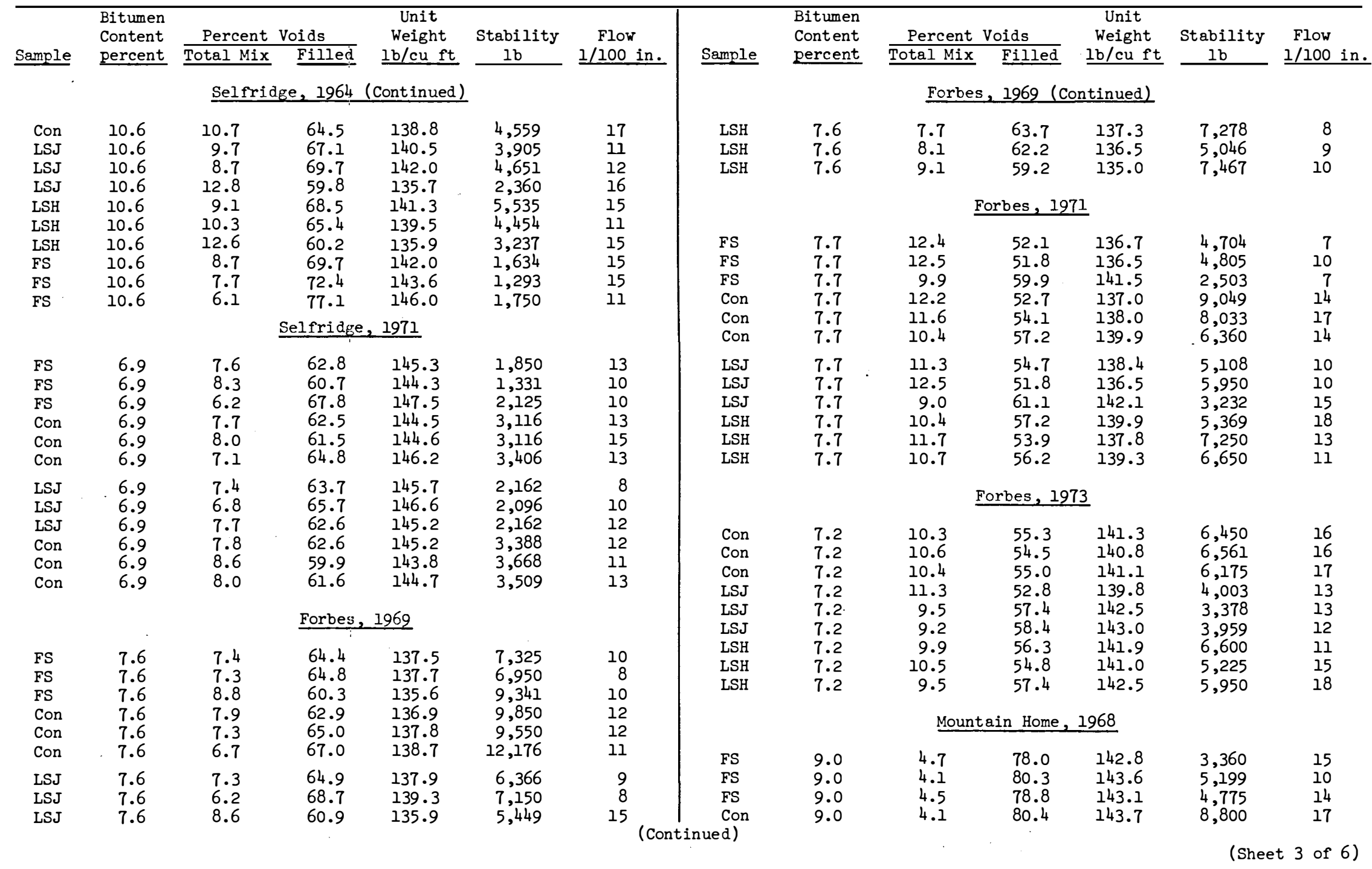


Table 1 (Continued)

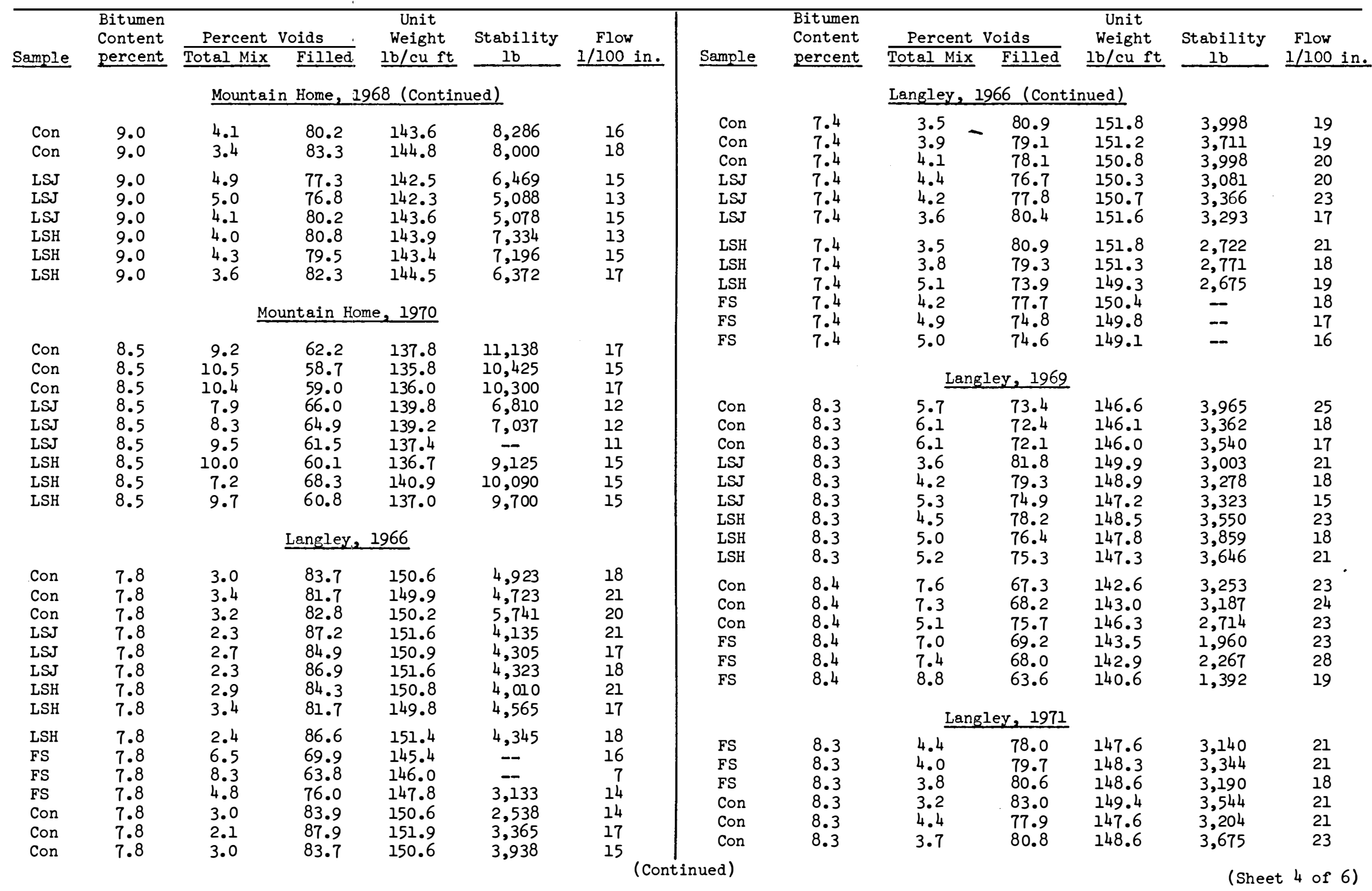


Table 1 (Continued)

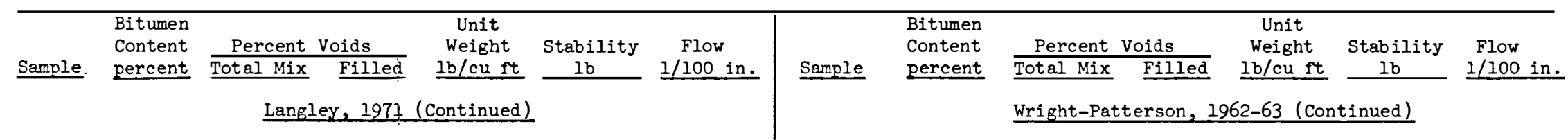

$\begin{array}{llllll}\text { LSJ } & 8.3 & 3.8 & 80.3 & 148.4 & 2,830 \\ \text { LSJ } & 8.3 & 3.5 & 81.9 & 149.9 & 3,121 \\ \text { LSJ } & 8.3 & 3.4 & 82.1 & 149.1 & 3,308 \\ \text { LSH } & 8.3 & 3.9 & 80.1 & 148.4 & 3,475 \\ \text { LSH } & 8.3 & 4.6 & 76.9 & 147.2 & 2,996 \\ \text { LSH } & 8.3 & 4.8 & 76.1 & 146.9 & 3,239 \\ \text { FS } & 8.3 & 4.9 & 76.0 & 146.8 & 2,860 \\ \text { FS } & 8.3 & 5.5 & 73.7 & 145.9 & 3,246 \\ \text { FS } & 8.3 & 5.2 & 74.9 & 146.4 & 3,600 \\ \text { Con } & 8.3 & 8.5 & 63.6 & 141.3 & 3,200 \\ \text { Con } & 8.3 & 6.4 & 70.3 & 144.5 & 2,625 \\ \text { Con } & 8.3 & 4.7 & 76.7 & 147.1 & 3,838\end{array}$

Wright-Patterson, 1960

$\begin{array}{ll}\text { Con } & 9.1 \\ \text { Con } & 9.1 \\ \text { FS } & 9.1 \\ \text { FS } & 9.1 \\ \text { FS } & 9.1 \\ \text { Con } & 9.1 \\ \text { Con } & 9.1 \\ \text { Con } & 9.1 \\ \text { LSJ } & 9.1 \\ \text { LSJ } & 9.1 \\ \text { LSJ } & 9.1 \\ \text { LSH } & 9.1 \\ \text { LSH } & 9.1 \\ \text { LSH } & 9.1\end{array}$

$\begin{array}{rrrrr}6.9 & 71.0 & 143.2 & 4,913 & 8 \\ 6.2 & 73.2 & 144.2 & 4,459 & 4 \\ 6.6 & 71.9 & 143.6 & 4,198 & 8 \\ 7.1 & 70.4 & 142.9 & 2,093 & 10 \\ 7.3 & 69.9 & 142.6 & 4,146 & 10 \\ 5.3 & 76.5 & 145.7 & 7,668 & 15 \\ 4.2 & 80.7 & 147.5 & 12,463 & 12 \\ 6.0 & 71.4 & 144.6 & 12,445 & 12 \\ 5.6 & 75.3 & 145.2 & 7,442 & 14 \\ 5.6 & 75.3 & 145.1 & 6,050 & 13 \\ 4.5 & 79.3 & 146.8 & 7,664 & 12 \\ 5.2 & 76.9 & 145.8 & 11,070 & 11 \\ 6.4 & 72.7 & 144.0 & 11,201 & 11 \\ 5.2 & 76.8 & 145.8 & 10,074 & 12\end{array}$

Wright-Patter:son, $1962-63$

$\begin{array}{llllll}\text { Con } & 10.3 & 4.7 & 80.6 & 145.3 & 4,659 \\ \text { Con } & 10.3 & 2.3 & 89.5 & 148.8 & 5,175 \\ \text { Con } & 10.3 & 1.9 & 91.2 & 149.4 & 4,950 \\ \text { LSJ } & 10.3 & 4.2 & 82.3 & 146.0 & 3,892 \\ \text { LSJ } & 10.3 & 5.7 & 76.9 & 143.6 & 5,385\end{array}$

\begin{tabular}{l|l}
12 & Con \\
Con \\
Con \\
17 & LSJ \\
16 & LSJ \\
15 & LSJ \\
15 & LSH \\
11 & LSH \\
LSH
\end{tabular}

$\begin{array}{lrrrrrr}\text { LSJ } & 10.3 & 5.1 & 79.3 & 144.7 & 3,550 & 16 \\ \text { LSH } & 10.3 & 5.9 & 76.5 & 143.5 & 3,114 & 11 \\ \text { LSH } & 10.3 & 5.8 & 76.9 & 143.6 & 4,386 & 12 \\ \text { LSH } & 10.3 & 5.8 & 76.9 & 143.6 & 2,947 & 12 \\ \text { FS } & 10.3 & 1.0 & 95.1 & 150.8 & 4,675 & 16 \\ \text { FS } & 10.3 & 3.7 & 83.9 & 146.6 & 3,449 & 9 \\ \text { FS } & 10.3 & 1.0 & 95.3 & 150.9 & 2,836 & 10 \\ \text { FS } & 10.3 & 2.4 & 89.9 & 148.9 & 3,336 & 14 \\ \text { FS } & 10.3 & 4.1 & 82.5 & 146.1 & 2,904 & 9 \\ \text { FS } & 10.3 & 2.4 & 89.3 & 148.8 & 4,970 & 16\end{array}$

Wright-Patterson, 1970

$\begin{array}{lllll}5.4 & 75.1 & 147.6 & 6,000 & 14 \\ 6.9 & 70.0 & 145.2 & 6,461 & 14 \\ 6.2 & 72.6 & 146.5 & 6,561 & 19 \\ 5.8 & 73.9 & 147.0 & 3,558 & 15 \\ 6.6 & 71.1 & 145.8 & 3,000 & 11 \\ 6.3 & 72.0 & 146.1 & 3,294 & 10 \\ 5.0 & 76.7 & 148.2 & 5,929 & 18 \\ 5.6 & 74.4 & 147.3 & 4,024 & 11 \\ 6.6 & 71.2 & 145.8 & 5,150 & 12\end{array}$

Wright-Patterson, 1972

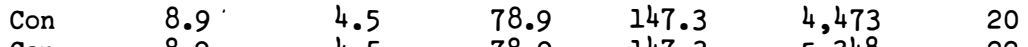

$\begin{array}{lllllll}\text { Con } & 8.9 & 4.5 & 78.9 & 147.3 & 5,348 & 22 \\ \text { Con } & 8.9 & 4.2 & 80.3 & 147.8 & 5,082 & 20\end{array}$

Rickenbacker, 1963

\begin{tabular}{|c|c|c|c|c|}
\hline- & - & 133.5 & 3,280 & 10 \\
\hline -- & -- & 135.4 & 2,800 & 10 \\
\hline- & - & 138.5 & 3,850 & 11 \\
\hline-- & -- & 142.3 & 4,750 & 7 \\
\hline-- & - & 139.2 & 3,300 & 5 \\
\hline -- & -- & 138.5 & 3,900 & 7 \\
\hline- & - & 141.0 & 4,186 & 7 \\
\hline -- & -- & 139.2 & 3,725 & 8 \\
\hline -- & - & 134.2 & 3,200 & 6 \\
\hline
\end{tabular}

(Sheet 5 of 6 ) 
Table 1 (Concluded)

\begin{tabular}{|c|c|c|c|c|c|c|c|c|c|c|c|c|c|}
\hline Sample & $\begin{array}{l}\text { Bitumen } \\
\text { Content } \\
\text { percent }\end{array}$ & $\begin{array}{l}\text { Percent } \\
\text { Total Mix }\end{array}$ & $\begin{array}{l}\text { Voids } \\
\text { Filled }\end{array}$ & $\begin{array}{c}\text { Unit } \\
\text { Weight } \\
\text { Ib/cu ft } \\
\end{array}$ & $\begin{array}{c}\text { Stability } \\
\text { lb }\end{array}$ & $\begin{array}{l}\text { Flow } \\
1 / 100 \text { in. }\end{array}$ & Sample & $\begin{array}{l}\text { Bitumen } \\
\text { Content } \\
\text { percent }\end{array}$ & $\begin{array}{r}\text { Percent } \\
\text { Total Mix }\end{array}$ & $\begin{array}{l}\text { Voids } \\
\text { Filled }\end{array}$ & $\begin{array}{c}\text { Unit } \\
\text { Weight } \\
\text { lb/cu ft } \\
\end{array}$ & $\begin{array}{c}\text { Stability } \\
1 \mathrm{~b}\end{array}$ & $\begin{array}{l}\text { Flow } \\
1 / 100 \text { in }\end{array}$ \\
\hline \multicolumn{7}{|c|}{ Rickenbdcker, 1966} & \multicolumn{7}{|c|}{ Rickenbacker, 1968 (Continued) } \\
\hline $\begin{array}{l}\text { Con } \\
\text { Con } \\
\text { FS } \\
\text { FS } \\
\text { FS } \\
\text { Con } \\
\text { Con }\end{array}$ & $\begin{array}{l}7.6 \\
7.6 \\
7.6 \\
7.6 \\
7.6 \\
7.6 \\
7.6\end{array}$ & $\begin{array}{l}4.1 \\
5.9 \\
4.6 \\
3.7 \\
4.1 \\
5.1 \\
4.7\end{array}$ & $\begin{array}{l}78.3 \\
70.9 \\
76.0 \\
79.9 \\
78.4 \\
74.2 \\
76.0\end{array}$ & $\begin{array}{l}149.1 \\
146.0 \\
148.5 \\
149.8 \\
149.8 \\
147.9 \\
148.5\end{array}$ & $\begin{array}{l}2,969 \\
3,696 \\
5,261 \\
6,394 \\
6,546 \\
7,353 \\
7,211\end{array}$ & $\begin{array}{l}14 \\
13 \\
13 \\
15 \\
14 \\
13 \\
14\end{array}$ & $\begin{array}{l}\text { FS } \\
\text { FS } \\
\text { Con } \\
\text { Con } \\
\text { Con } \\
\text { LSJ } \\
\text { LSJ }\end{array}$ & $\begin{array}{l}7.2 \\
7.2 \\
7.2 \\
7.2 \\
7.2 \\
7.2 \\
7.2\end{array}$ & $\begin{array}{l}8.7 \\
7.8 \\
5.6 \\
6.1 \\
5.5 \\
5.0 \\
5.8\end{array}$ & $\begin{array}{l}60.6 \\
63.3 \\
71.2 \\
69.2 \\
71.5 \\
73.4 \\
70.4\end{array}$ & $\begin{array}{l}141.6 \\
143.5 \\
147.9 \\
146.0 \\
147.3 \\
147.9 \\
146.6\end{array}$ & $\begin{array}{r}11,289 \\
10,650 \\
9,904 \\
8,816 \\
9,163 \\
6,930 \\
6,584\end{array}$ & $\begin{array}{l}13 \\
10 \\
13 \\
15 \\
15 \\
15 \\
17\end{array}$ \\
\hline $\begin{array}{l}\text { Con } \\
\text { LSJ } \\
\text { LSJ } \\
\text { LSJ } \\
\text { LSH } \\
\text { LSH }\end{array}$ & $\begin{array}{l}7.6 \\
7.6 \\
7.6 \\
7.6 \\
7.6 \\
7.6\end{array}$ & $\begin{array}{l}4.8 \\
4.3 \\
5.1 \\
4.8 \\
4.6 \\
5.0\end{array}$ & $\begin{array}{l}75.2 \\
77.5 \\
74.3 \\
75.4 \\
76.0 \\
74.4\end{array}$ & $\begin{array}{l}148.5 \\
149.1 \\
147.9 \\
148.5 \\
148.5 \\
147.9\end{array}$ & $\begin{array}{l}5,875 \\
4,712 \\
4,580 \\
4,615 \\
6,402 \\
5,307\end{array}$ & $\begin{array}{l}12 \\
12 \\
16 \\
11 \\
17 \\
17\end{array}$ & $\begin{array}{l}\text { LSJ } \\
\text { LSH } \\
\text { LSH } \\
\text { LSH }\end{array}$ & $\begin{array}{l}7.2 \\
7.2 \\
7.2 \\
7.2\end{array}$ & $\begin{array}{l}6.7 \\
7.1 \\
6.6 \\
7.9 \\
\text { Ricken } \\
\end{array}$ & $\begin{array}{r}67.1 \\
65.6 \\
67.5 \\
62.9 \\
\text { backer, } 1 \\
\end{array}$ & $\begin{array}{l}145.4 \\
144.8 \\
145.4 \\
143.5\end{array}$ & $\begin{array}{l}7,238 \\
8,715 \\
8,740 \\
8,817\end{array}$ & $\begin{array}{l}14 \\
13 \\
14 \\
13\end{array}$ \\
\hline LSH & 7.6 & 4.5 & $\begin{array}{r}76.5 \\
\text { Rickenback } \\
\end{array}$ & $\begin{array}{r}148.5 \\
r, \quad 1968 \\
\end{array}$ & 5,962 & 17 & $\begin{array}{l}\text { Con } \\
\text { Con } \\
\text { Con }\end{array}$ & $\begin{array}{l}7.1 \\
7.1 \\
7.1\end{array}$ & $\begin{array}{r}8.6 \\
9.4 \\
11.2\end{array}$ & $\begin{array}{l}61.9 \\
58.5 \\
53.5\end{array}$ & $\begin{array}{l}144.8 \\
142.9 \\
140.4\end{array}$ & $\begin{array}{l}5,421 \\
5,989 \\
4,931\end{array}$ & $\begin{array}{r}21 \\
15 \\
8\end{array}$ \\
\hline $\begin{array}{l}\text { FS } \\
\text { FS } \\
\text { FS }\end{array}$ & $\begin{array}{l}7.9 \\
7.9 \\
7.9\end{array}$ & $\begin{array}{l}9.1 \\
5.8 \\
5.1\end{array}$ & $\begin{array}{l}61.8 \\
72.3 \\
75.0\end{array}$ & $\begin{array}{l}142.3 \\
147.3 \\
148.5\end{array}$ & $\begin{array}{r}9,135 \\
5,915 \\
11,786\end{array}$ & $\begin{array}{l}10 \\
12 \\
16\end{array}$ & $\begin{array}{l}\text { FS } \\
\text { FS } \\
\text { FS }\end{array}$ & $\begin{array}{l}7.1 \\
7.1 \\
7.1\end{array}$ & $\begin{array}{l}7.6 \\
7.9 \\
8.5\end{array}$ & $\begin{array}{l}64.1 \\
63.1 \\
61.1\end{array}$ & $\begin{array}{l}146.0 \\
145.4 \\
144.8\end{array}$ & $\begin{array}{l}4,250 \\
4,392 \\
4,615\end{array}$ & $\begin{array}{l}13 \\
12 \\
14\end{array}$ \\
\hline $\begin{array}{l}\text { Con } \\
\text { Con } \\
\text { LSJ } \\
\text { LSJ } \\
\text { LSH }\end{array}$ & $\begin{array}{l}7.9 \\
7.9 \\
7.9 \\
7.9 \\
7.9\end{array}$ & $\begin{array}{l}6.0 \\
7.7 \\
5.4 \\
7.3 \\
5.5\end{array}$ & $\begin{array}{l}71.6 \\
65.8 \\
73.8 \\
67.2 \\
73.6\end{array}$ & $\begin{array}{l}147.3 \\
144.1 \\
147.9 \\
145.4 \\
147.9\end{array}$ & $\begin{array}{r}12,567 \\
12,707 \\
8,733 \\
11,238 \\
7,714\end{array}$ & $\begin{array}{r}13 \\
10 \\
10 \\
8 \\
13\end{array}$ & $\begin{array}{l}\text { FS } \\
\text { FS } \\
\text { FS } \\
\text { Con } \\
\text { Con }\end{array}$ & $\begin{array}{l}7.1 \\
7.1 \\
7.1 \\
7.1 \\
7.1\end{array}$ & $\begin{array}{r}9.2 \\
8.7 \\
10.2 \\
7.3 \\
8.6\end{array}$ & $\begin{array}{l}59.9 \\
60.4 \\
56.2 \\
65.1 \\
60.9\end{array}$ & $\begin{array}{l}143.5 \\
144.1 \\
141.6 \\
146.6 \\
141.1\end{array}$ & $\begin{array}{l}4,144 \\
4,978 \\
4,991 \\
5,999 \\
5,425\end{array}$ & $\begin{array}{l}15 \\
14 \\
14 \\
14 \\
14\end{array}$ \\
\hline $\begin{array}{l}\text { Con } \\
\text { Con } \\
\text { Con } \\
\text { LSJ } \\
\text { LSJ } \\
\text { LSJ } \\
\text { LSH } \\
\text { LSH } \\
\text { LSH }\end{array}$ & $\begin{array}{l}7.8 \\
7.8 \\
7.8 \\
7.8 \\
7.8 \\
7.8 \\
7.8 \\
7.8 \\
7.8\end{array}$ & $\begin{array}{l}6.6 \\
7.9 \\
7.1 \\
7.9 \\
9.3 \\
7.9 \\
7.6 \\
8.4 \\
8.0\end{array}$ & $\begin{array}{l}69.0 \\
64.9 \\
67.3 \\
64.6 \\
60.6 \\
64.8 \\
65.7 \\
63.2 \\
64.3\end{array}$ & $\begin{array}{l}145.4 \\
144.8 \\
144.1 \\
142.9 \\
141.0 \\
143.5 \\
143.5 \\
142.3 \\
143.0\end{array}$ & $\begin{array}{r}11,676 \\
12,454 \\
15,068 \\
4,375 \\
9,508 \\
8,840 \\
12,621 \\
12,844 \\
11,203\end{array}$ & $\begin{array}{r}8 \\
13 \\
11 \\
19 \\
6 \\
6 \\
10 \\
8 \\
9\end{array}$ & $\begin{array}{l}\text { Con } \\
\text { LSJ } \\
\text { LSJ } \\
\text { LSJ } \\
\text { LSH } \\
\text { LSH } \\
\text { LSH }\end{array}$ & $\begin{array}{l}7.1 \\
7.1 \\
7.1 \\
7.1 \\
7.1 \\
7.1 \\
7.1\end{array}$ & $\begin{array}{l}7.3 \\
8.4 \\
7.5 \\
7.4 \\
9.3 \\
7.6 \\
8.8\end{array}$ & $\begin{array}{l}65.1 \\
61.3 \\
64.3 \\
64.5 \\
58.8 \\
64.0 \\
61.9\end{array}$ & $\begin{array}{l}144.6 \\
144.8 \\
144.6 \\
144.6 \\
143.5 \\
146.0 \\
144.8\end{array}$ & $\begin{array}{l}6,106 \\
3,763 \\
3,444 \\
3,930 \\
4,982 \\
5,404 \\
5,076\end{array}$ & $\begin{array}{l}15 \\
11 \\
14 \\
11 \\
11 \\
14 \\
11\end{array}$ \\
\hline
\end{tabular}


Table 2

Effects of Soaking* in Hydraulic Fluid and Jet Fuel on Density,

Stability, and Flow of Pavement Samples

\begin{tabular}{|c|c|c|c|c|c|}
\hline \multirow[b]{2}{*}{ Sample } & \multicolumn{3}{|c|}{ Density, $1 \mathrm{~b} / \mathrm{cu} \mathrm{ft}$} & \multicolumn{2}{|c|}{ After Draining $120 \mathrm{hr}$} \\
\hline & Original & $\begin{array}{l}\text { After Draining } \\
24 \mathrm{hr} \\
\end{array}$ & $\begin{array}{l}\text { After Draining } \\
120 \mathrm{hr} \\
\end{array}$ & $\begin{array}{l}\text { Stability } \\
1 \mathrm{~b} \\
\end{array}$ & $\begin{array}{c}\text { Flow } \\
1 / 100 \mathrm{in} .\end{array}$ \\
\hline & & Selfrid & 1971 & & \\
\hline Control & $\begin{array}{l}144.5 \\
144.1 \\
144.5\end{array}$ & $\begin{array}{l}-- \\
--\end{array}$ & $\begin{array}{l}-- \\
--\end{array}$ & $\begin{array}{l}3088 \\
3836 \\
3133\end{array}$ & $\begin{array}{l}17 \\
20 \\
16\end{array}$ \\
\hline $\begin{array}{l}\text { Soaked in } \\
\mathrm{JP}-4\end{array}$ & $\begin{array}{l}150.7 \\
150.6 \\
150.3\end{array}$ & $\begin{array}{l}151.1 \\
151.0 \\
150.6\end{array}$ & $\begin{array}{l}150.9 \\
151.1 \\
150.6\end{array}$ & $\begin{array}{l}2611 \\
2247 \\
2293\end{array}$ & $\begin{array}{l}19 \\
18 \\
17\end{array}$ \\
\hline $\begin{array}{l}\text { Soaked in } \\
\text { hydraulic } \\
\text { fluid }\end{array}$ & $\begin{array}{l}146.5 \\
146.3 \\
145.5\end{array}$ & $\begin{array}{l}147.8 \\
147.8 \\
147.0\end{array}$ & $\begin{array}{l}147.6 \\
147.6 \\
147.0\end{array}$ & $\begin{array}{l}2894 \\
3519 \\
2825\end{array}$ & $\begin{array}{l}17 \\
18 \\
19\end{array}$ \\
\hline \multicolumn{6}{|c|}{ Forbes, 1972} \\
\hline Control & $\begin{array}{l}135.7 \\
135.3 \\
135.0\end{array}$ & -- & -- & $\begin{array}{l}4196 \\
3939 \\
4623\end{array}$ & $\begin{array}{l}20 \\
20 \\
20\end{array}$ \\
\hline $\begin{array}{l}\text { Soaked in } \\
\mathrm{JP}-4\end{array}$ & $\begin{array}{l}132.5 \\
132.7 \\
135.5\end{array}$ & $\begin{array}{l}138.2 \\
138.2 \\
138.5\end{array}$ & $\begin{array}{l}132.8 \\
133.8 \\
135.3\end{array}$ & $\begin{array}{l}2950 \\
3159 \\
4995\end{array}$ & $\begin{array}{r}25 \\
11 \\
5\end{array}$ \\
\hline $\begin{array}{l}\text { Soaked in } \\
\text { hydraulic } \\
\text { fluid }\end{array}$ & $\begin{array}{l}133.3 \\
135.5 \\
132.6\end{array}$ & $\begin{array}{l}134.9 \\
137.9 \\
135.2\end{array}$ & $\begin{array}{l}136.7 \\
138.3 \\
135.8\end{array}$ & $\begin{array}{l}4149 \\
5030 \\
3998\end{array}$ & $\begin{array}{r}10 \\
9 \\
7\end{array}$ \\
\hline \multicolumn{6}{|c|}{ Wright-Patterson, 1960} \\
\hline Control & $\begin{array}{l}151.8 \\
149.9\end{array}$ & -- & - & $\begin{array}{l}4459 \\
4948\end{array}$ & $\begin{array}{l}15 \\
15\end{array}$ \\
\hline $\begin{array}{l}\text { Soaked in } \\
\mathrm{JP}-4\end{array}$ & $\begin{array}{l}150.8 \\
150.2 \\
150.3\end{array}$ & $\begin{array}{l}150.5 \\
150.1 \\
150.1\end{array}$ & $\begin{array}{l}150.7 \\
150.2 \\
150.1\end{array}$ & $\begin{array}{l}3450 \\
4054 \\
3350\end{array}$ & $\begin{array}{l}13 \\
16 \\
16\end{array}$ \\
\hline $\begin{array}{l}\text { Soaked in } \\
\text { hydraulic } \\
\text { fluid }\end{array}$ & $\begin{array}{l}151.7 \\
151.8\end{array}$ & $\begin{array}{l}152.1 \\
152.1\end{array}$ & $\begin{array}{l}152.0 \\
151.9\end{array}$ & $\begin{array}{l}5560 \\
4850\end{array}$ & $\begin{array}{l}16 \\
15\end{array}$ \\
\hline \multicolumn{6}{|c|}{ Wright-Patterson, 1962-63 } \\
\hline Control & $\begin{array}{l}147.8 \\
141.5 \\
145.5\end{array}$ & -- & $\begin{array}{l}-- \\
--\end{array}$ & $\begin{array}{l}4043 \\
5880 \\
5830\end{array}$ & $\begin{array}{l}15 \\
10 \\
13\end{array}$ \\
\hline $\begin{array}{c}\text { Soaked in } \\
\mathrm{JP}-4\end{array}$ & $\begin{array}{l}145.3 \\
143.6 \\
147.2\end{array}$ & $\begin{array}{l}145.1 \\
143.6 \\
147.0\end{array}$ & $\begin{array}{l}145.0 \\
143.0 \\
146.6\end{array}$ & $\begin{array}{l}4520 \\
4175 \\
4100\end{array}$ & $\begin{array}{l}11 \\
11 \\
12\end{array}$ \\
\hline $\begin{array}{l}\text { Soaked in } \\
\text { hydraulic } \\
\text { fluid }\end{array}$ & $\begin{array}{l}146.5 \\
146.0 \\
146.6\end{array}$ & $\begin{array}{l}147.7 \\
146.6 \\
147.1\end{array}$ & $\begin{array}{l}147.0 \\
146.5 \\
146.9\end{array}$ & $\begin{array}{l}5210 \\
6171 \\
4235\end{array}$ & $\begin{array}{r}12 \\
12 \\
9\end{array}$ \\
\hline \multicolumn{6}{|c|}{ Wright-Patterson, 1966} \\
\hline Control & $\begin{array}{l}144.6 \\
146.6 \\
146.9\end{array}$ & -- & -- & $\begin{array}{l}7056 \\
4893 \\
6943\end{array}$ & $\begin{array}{r}10 \\
9 \\
9\end{array}$ \\
\hline $\begin{array}{c}\text { Soaked in } \\
\mathrm{JP}-4\end{array}$ & $\begin{array}{l}146.0 \\
146.4 \\
147.1\end{array}$ & $\begin{array}{l}146.1 \\
146.4 \\
147.1\end{array}$ & $\begin{array}{l}145.3 \\
145.8 \\
147.0\end{array}$ & $\begin{array}{l}3799 \\
3472 \\
3114\end{array}$ & $\begin{array}{r}5 \\
11 \\
11\end{array}$ \\
\hline $\begin{array}{l}\text { Soaked in } \\
\text { hydraulic } \\
\text { fluid. }\end{array}$ & $\begin{array}{l}148.1 \\
145.8 \\
147.3\end{array}$ & $\begin{array}{l}149.1 \\
146.6 \\
148.1\end{array}$ & $\begin{array}{l}148.8 \\
146.5 \\
148.0\end{array}$ & $\begin{array}{l}6232 \\
3058 \\
3905\end{array}$ & $\begin{array}{l}12 \\
12 \\
11\end{array}$ \\
\hline
\end{tabular}

* Core samples were soaked in the JP-4 or hydraulic fluid for 5 days. 


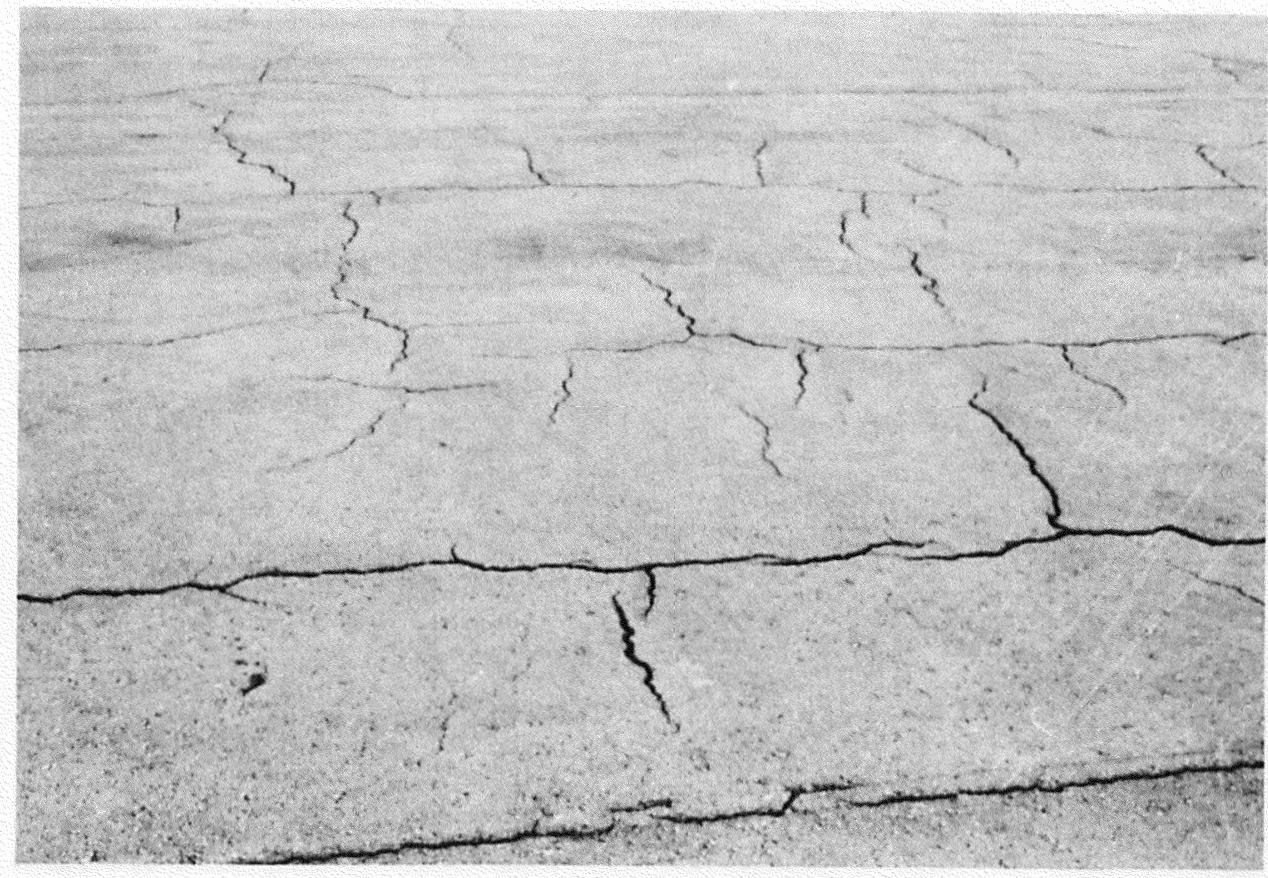

Photo 1. Block cracking in Homestead (1955) pavement

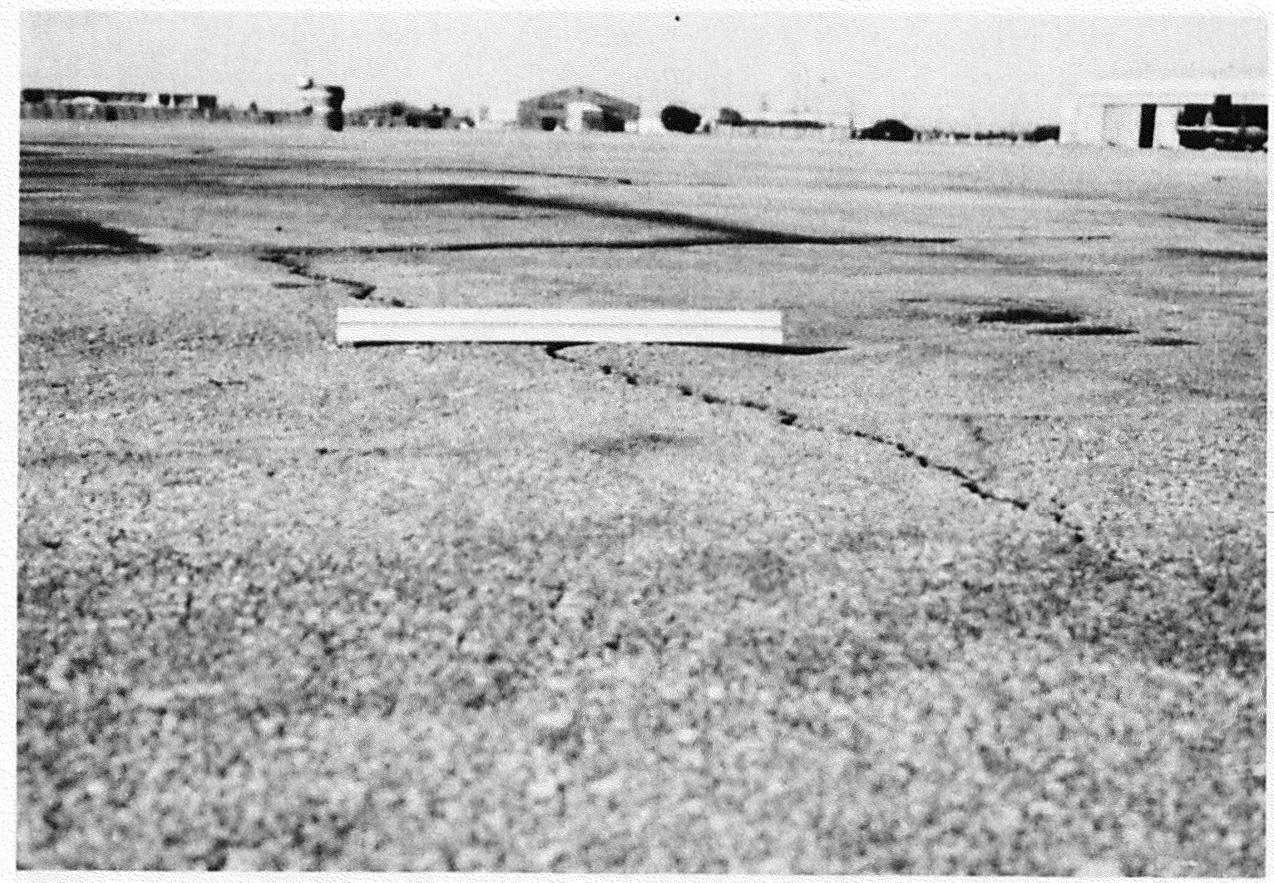

Photo 2. Unevenness on surface of Homestead (1955) pavement from cracking 


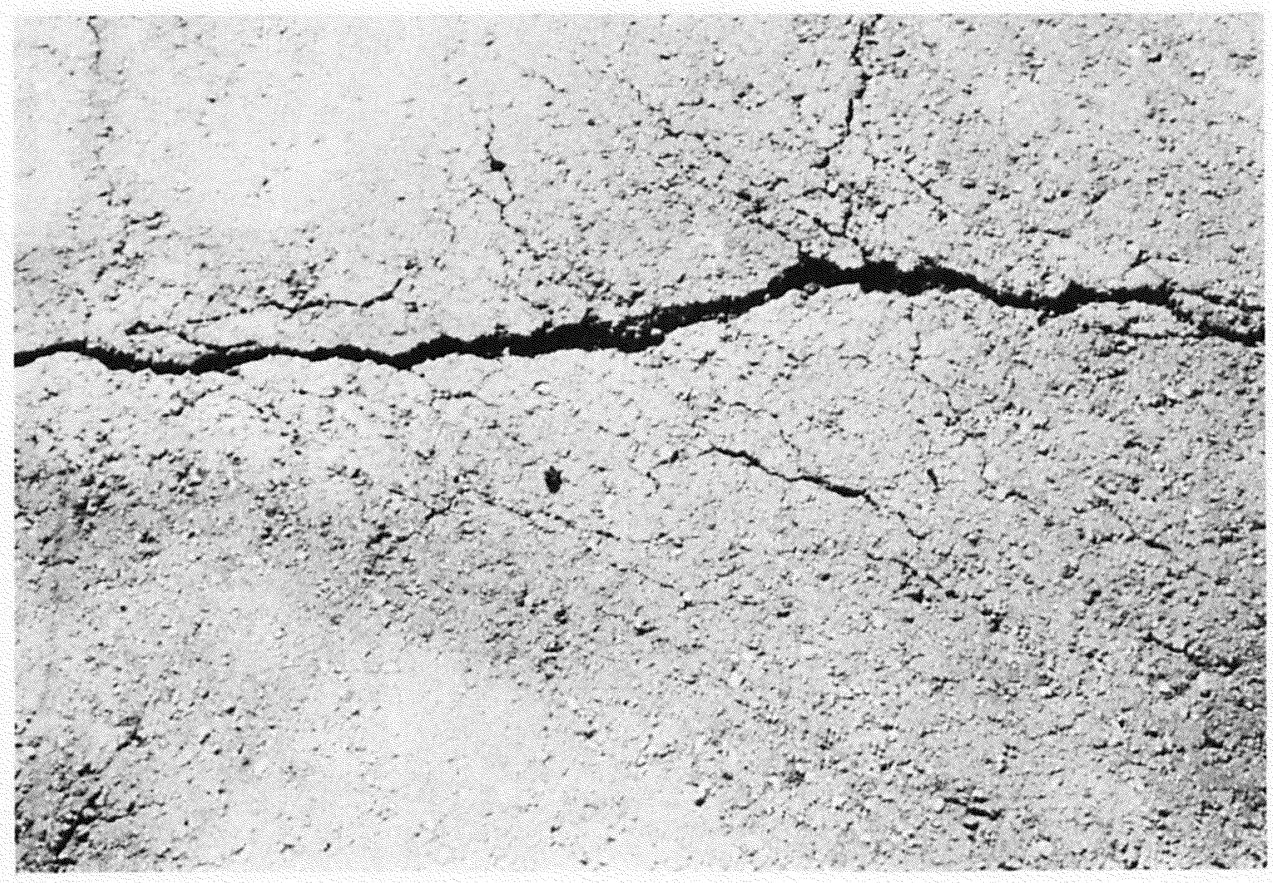

Photo 3. Slight depression at cracks in Homestead (1955) pavement

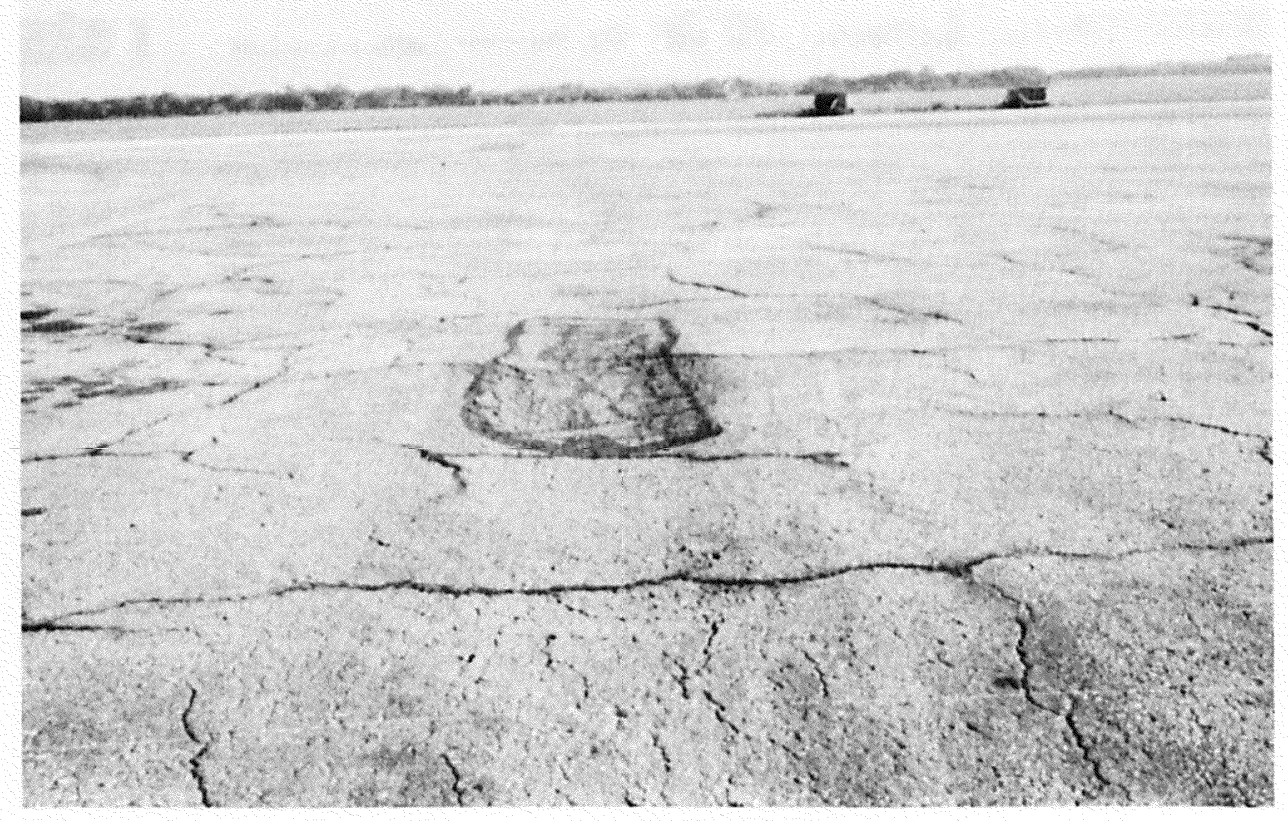

Photo 4. Rutting in taxiway on apron area of Homestead (1955) pavement 


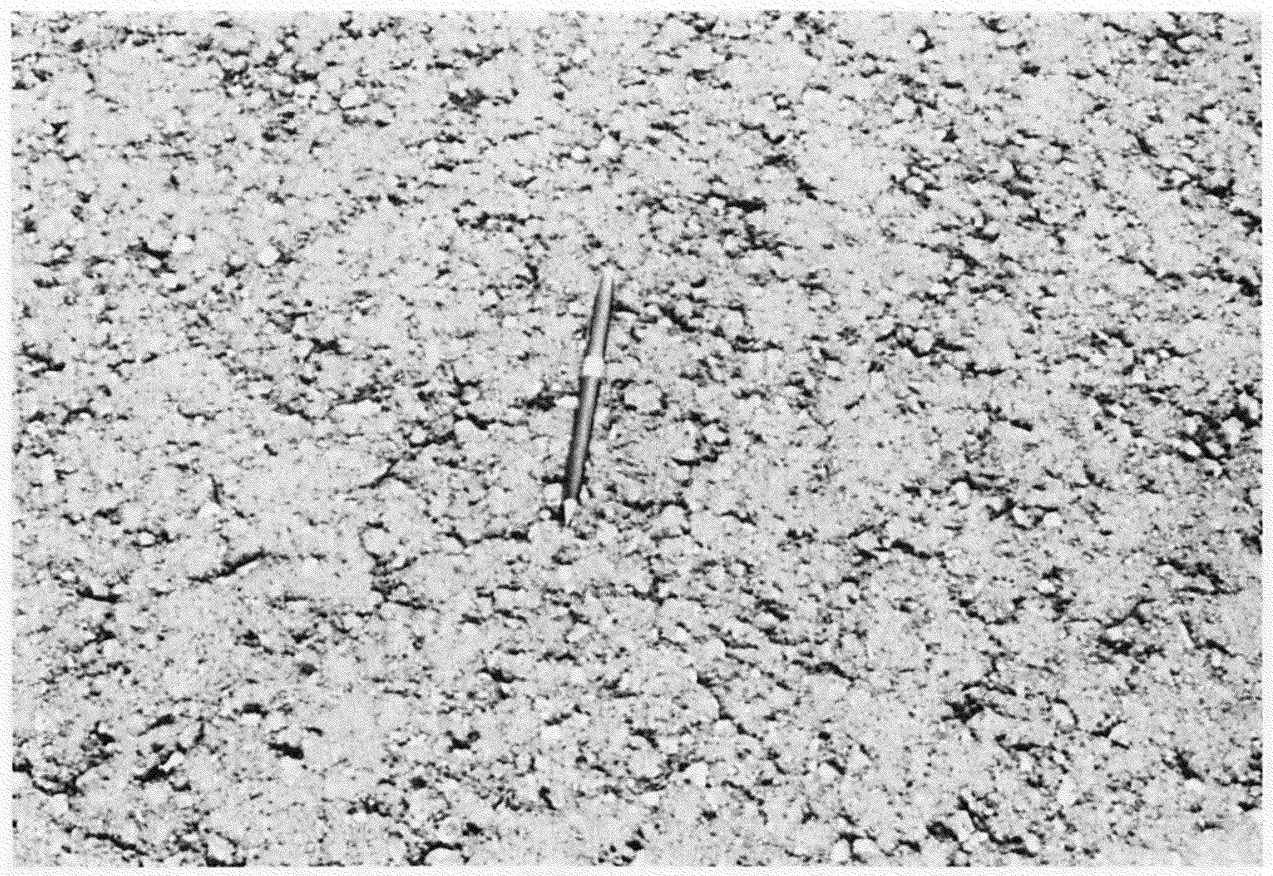

Photo 5. Rough texture of MacDill (1971) pavement, with surface appearing to contain only coarse aggregate

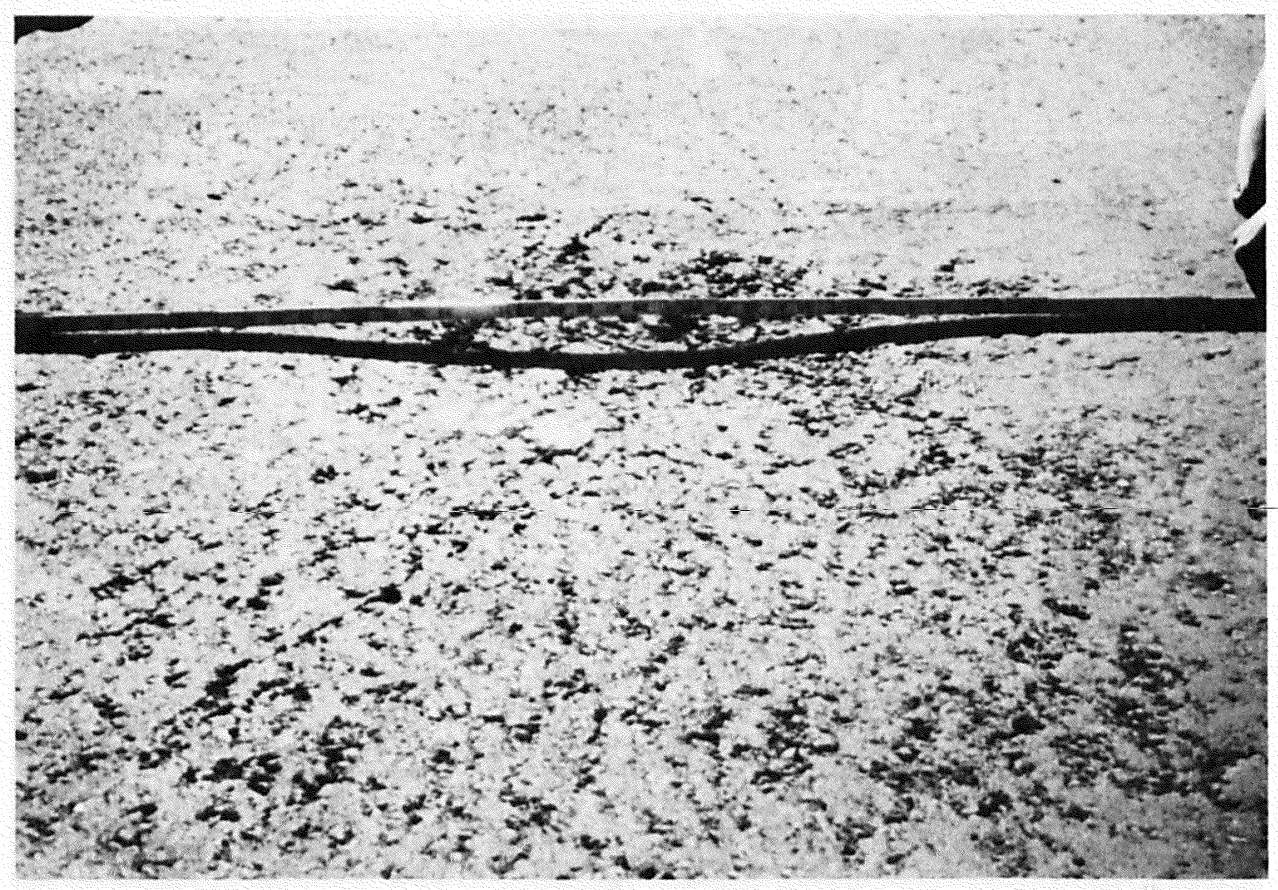

Photo 6. Pavement depression about $3 / 4$ in. deep in MacDill (1971) pavement 


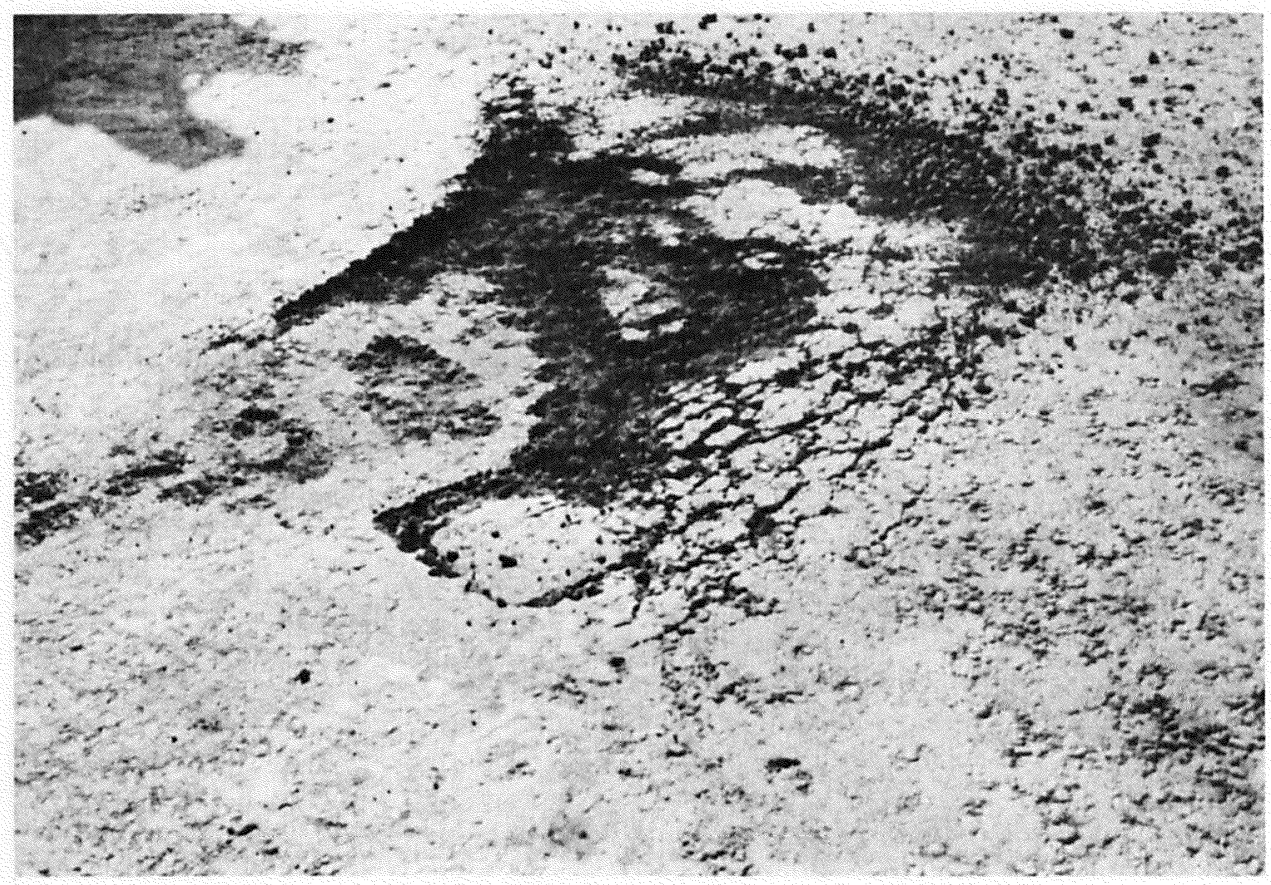

Photo 7. Pavement depression about $1-1 / 8$ in. deep in MacDill (1971) pavement

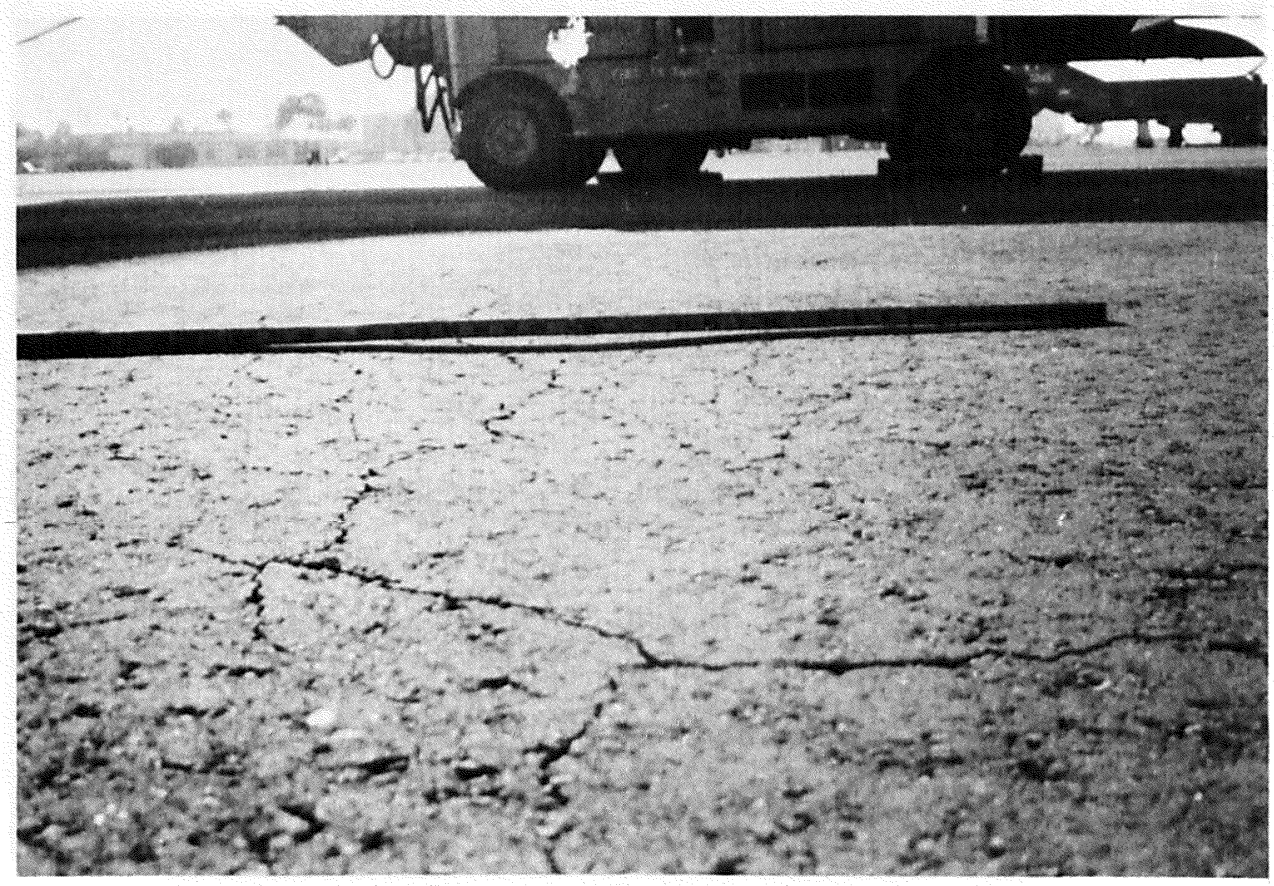

Photo 8. Ruts up to 1 in. deep in taxiway area of MacDill (1971) pavement 


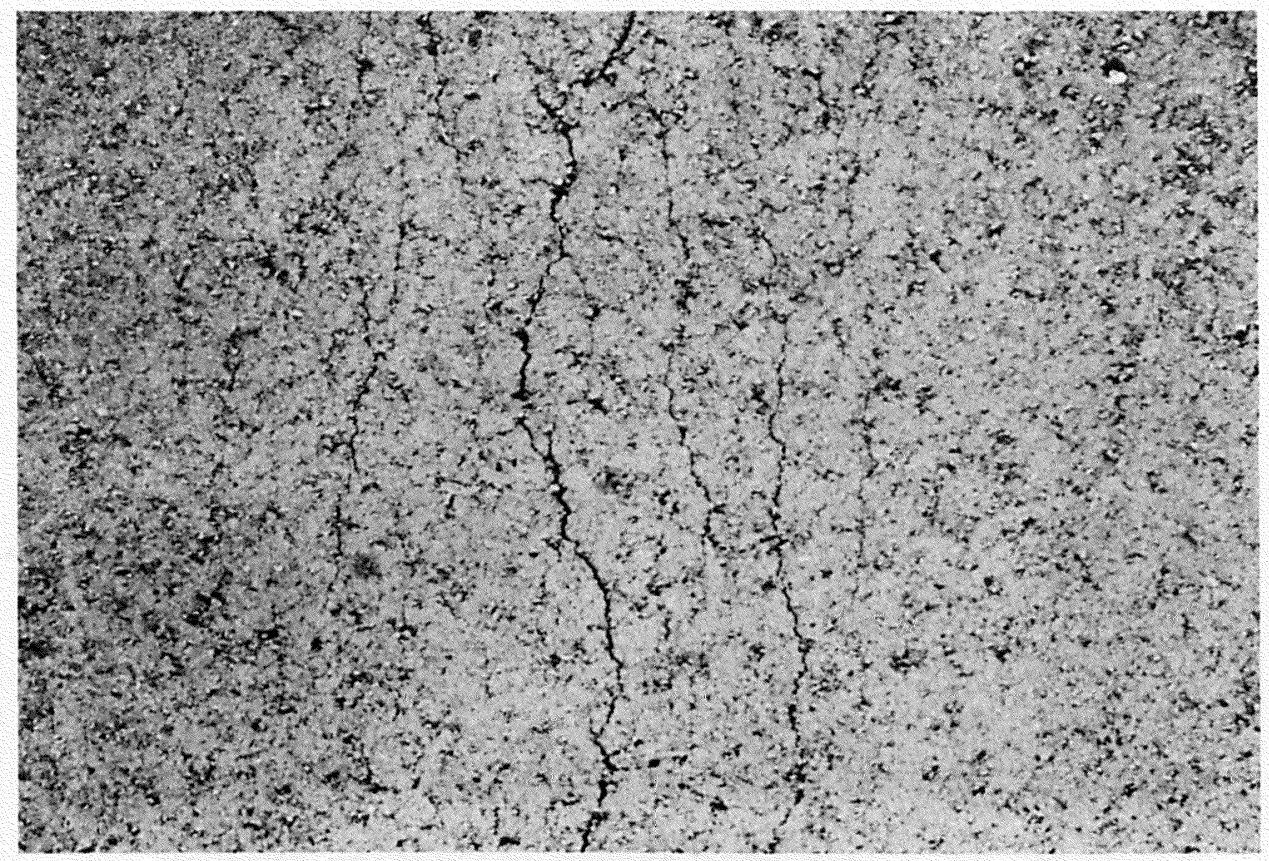

Photo 9. Longitudinal cracking in MacDill (1971) taxiway

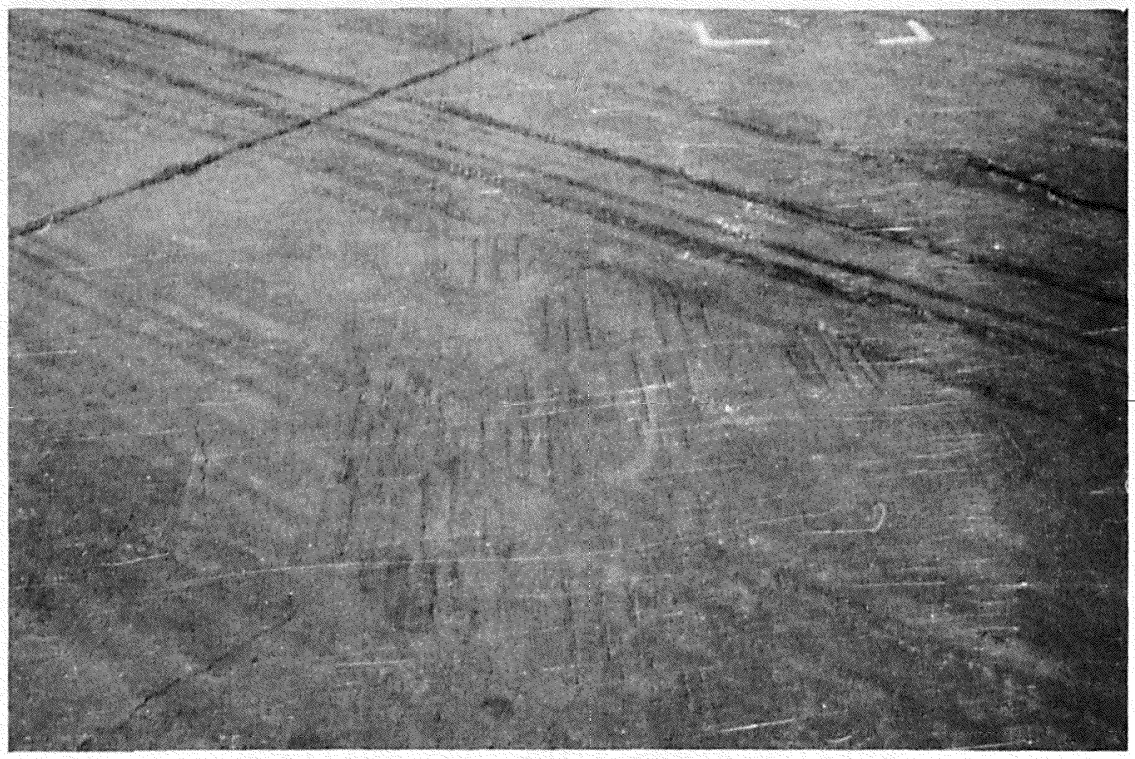

Photo 10. Aircraft tire printing in slurry seal of Selfridge (1964) pavement 


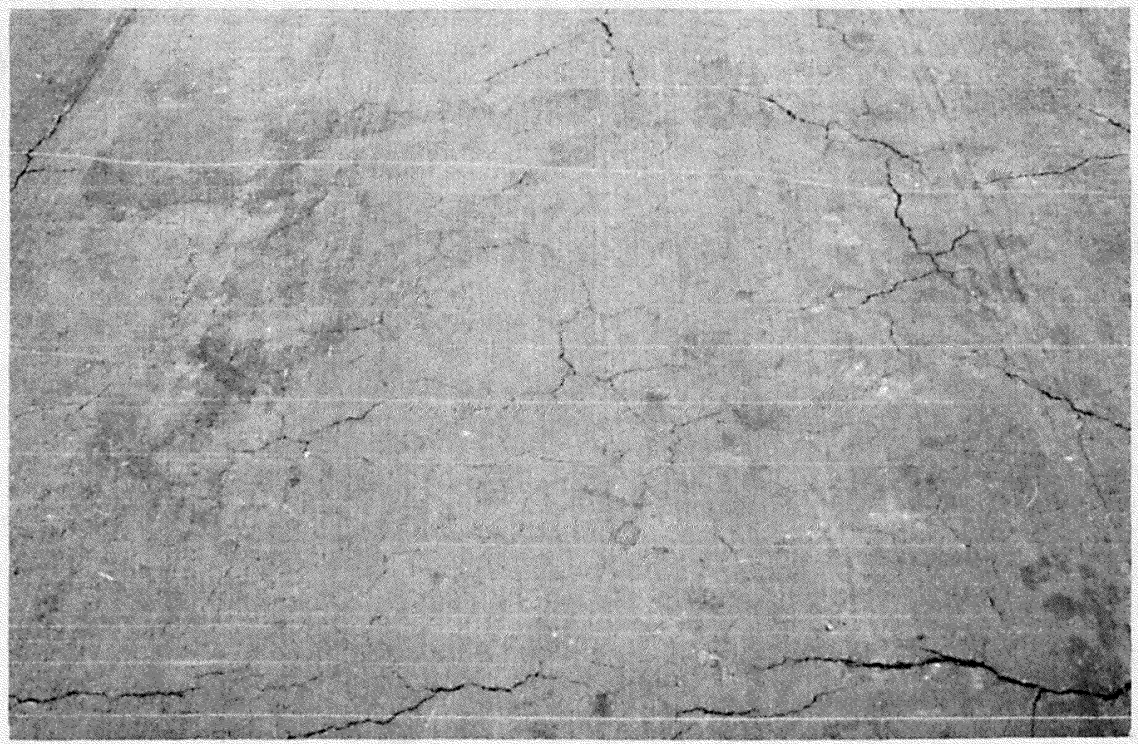

Photo 11. Shrinkage cracks reflecting through slurry seal of Selfridge (1964) pavement

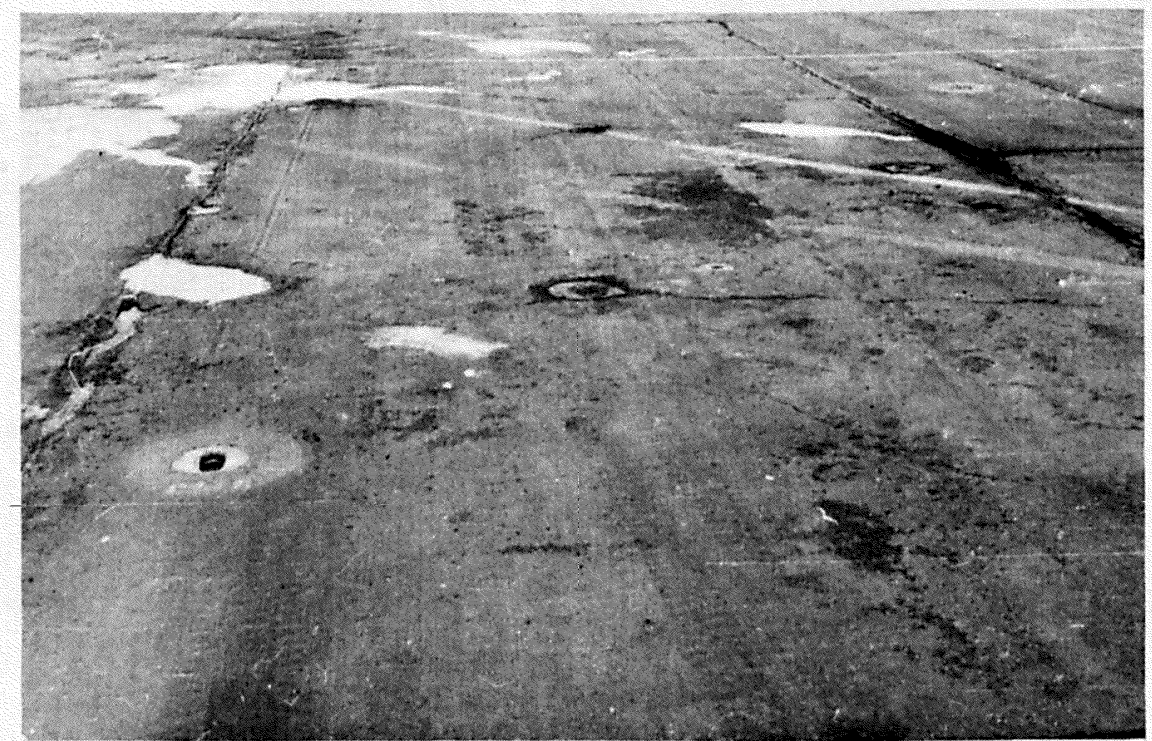

Photo 12. Slurry seal deterioration in Selfridge (1964) parking areas from fuel spillage 


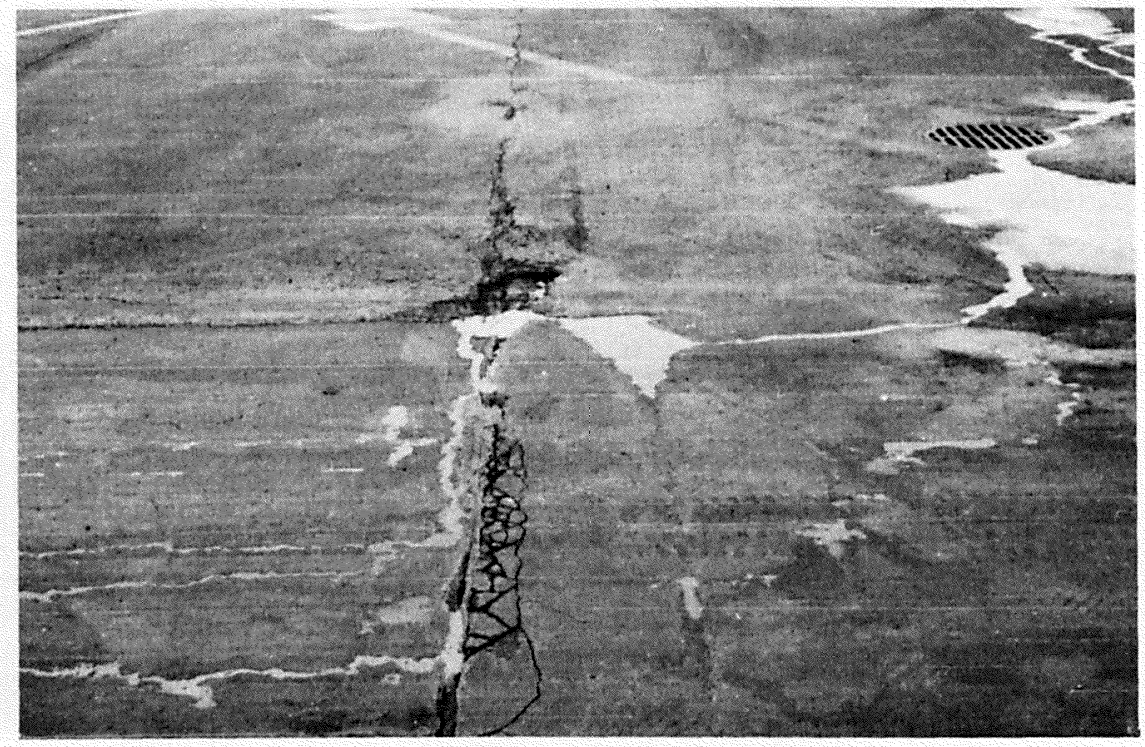

Photo 13. Joints spalling in Selfridge (1964) portland cement concrete and reflecting at surface

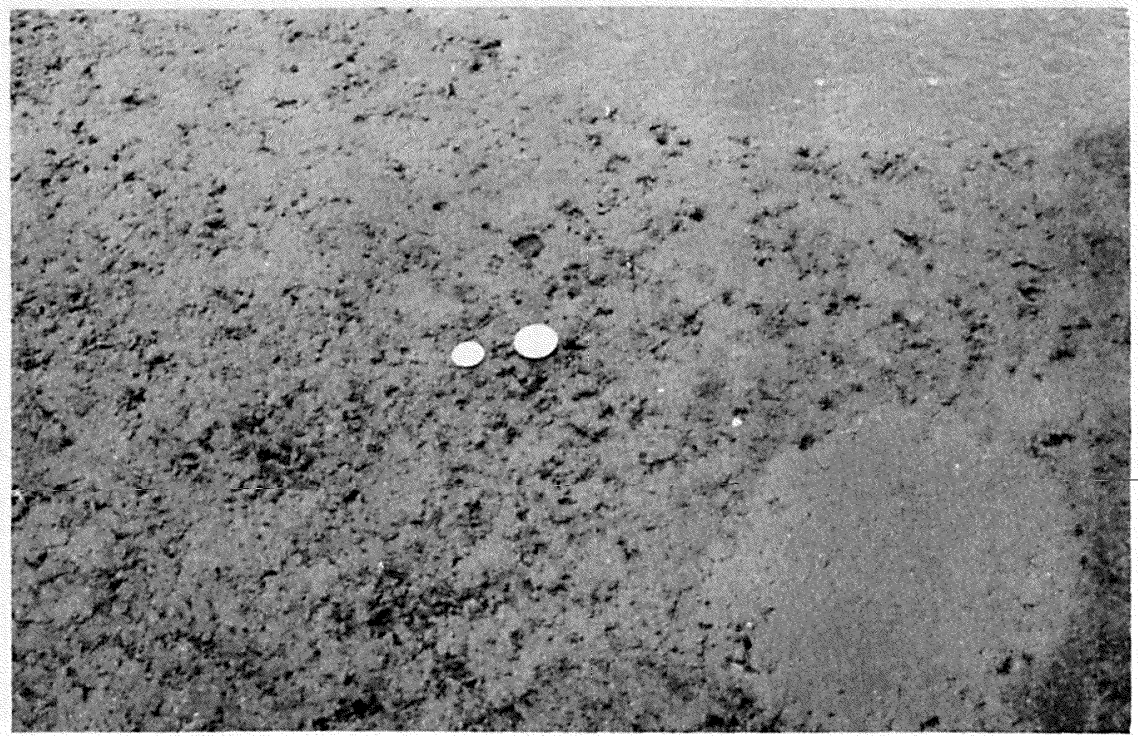

Photo 14. Minor deterioration in Selfridge (1971) pavement from hydraulic fluid spillage 


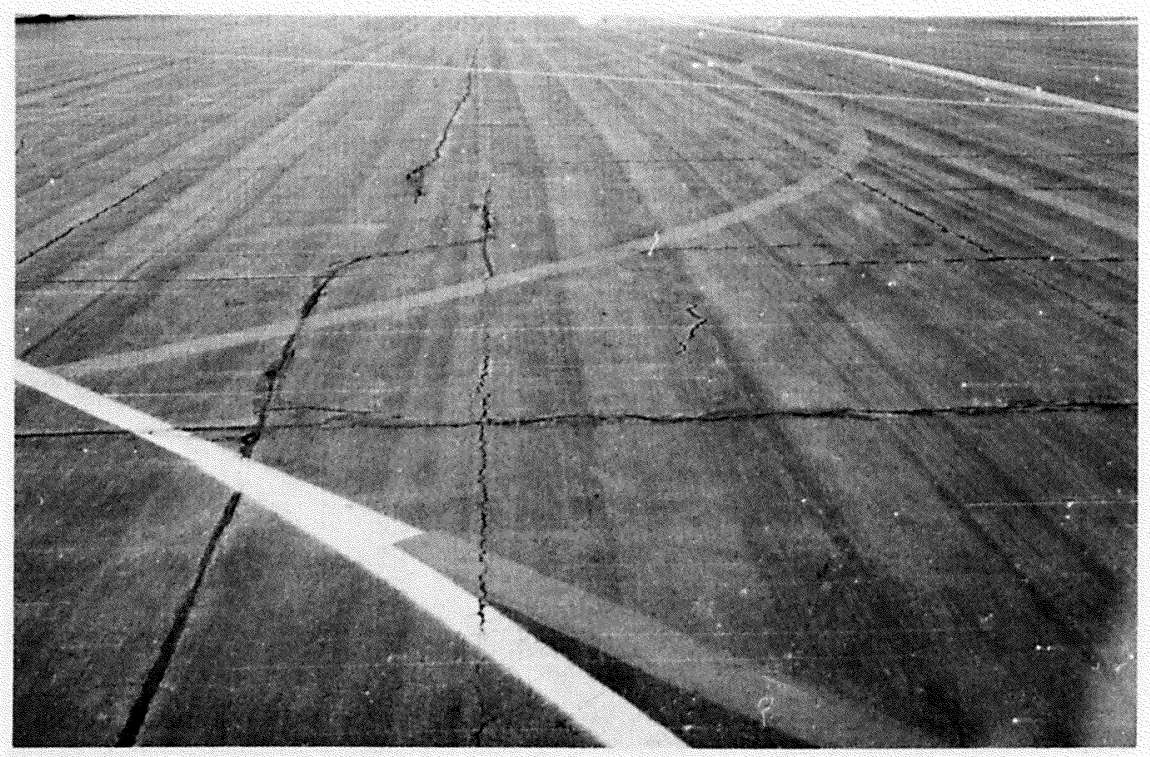

Photo 15. Construction joints and reflection cracking in surface of Selfridge (1971) pavement

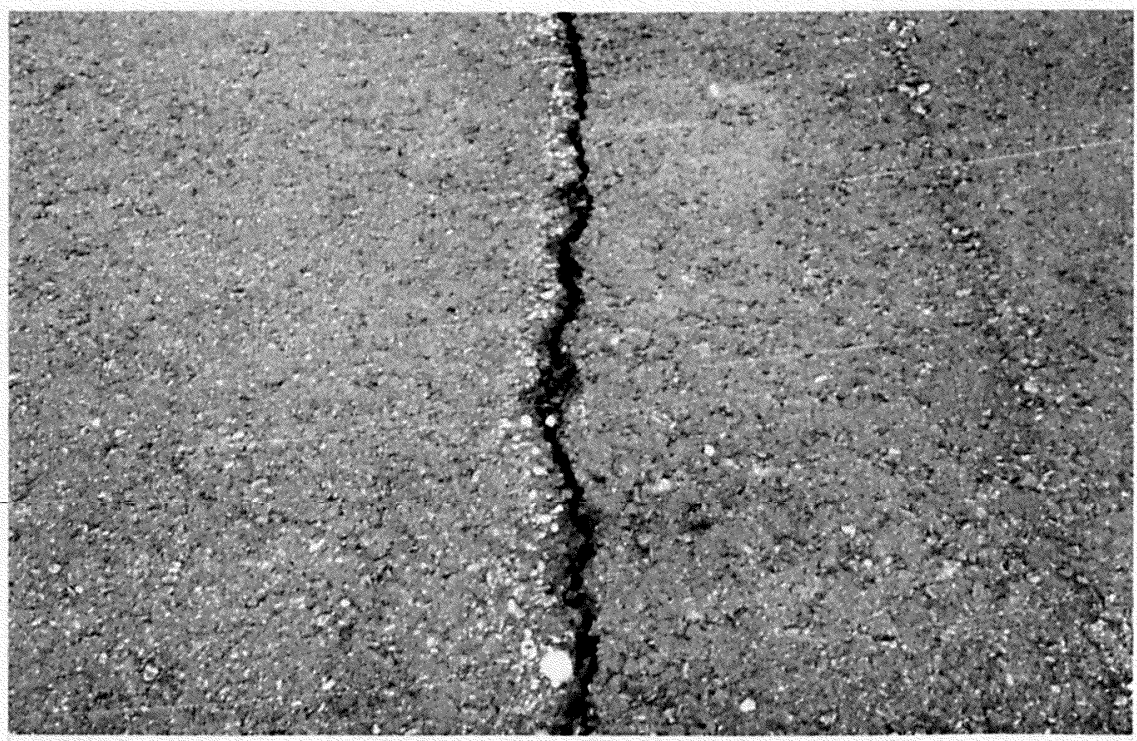

Photo 16. Selfridge (1971) pavement reflection crack showing signs of raveling and needing sealing 


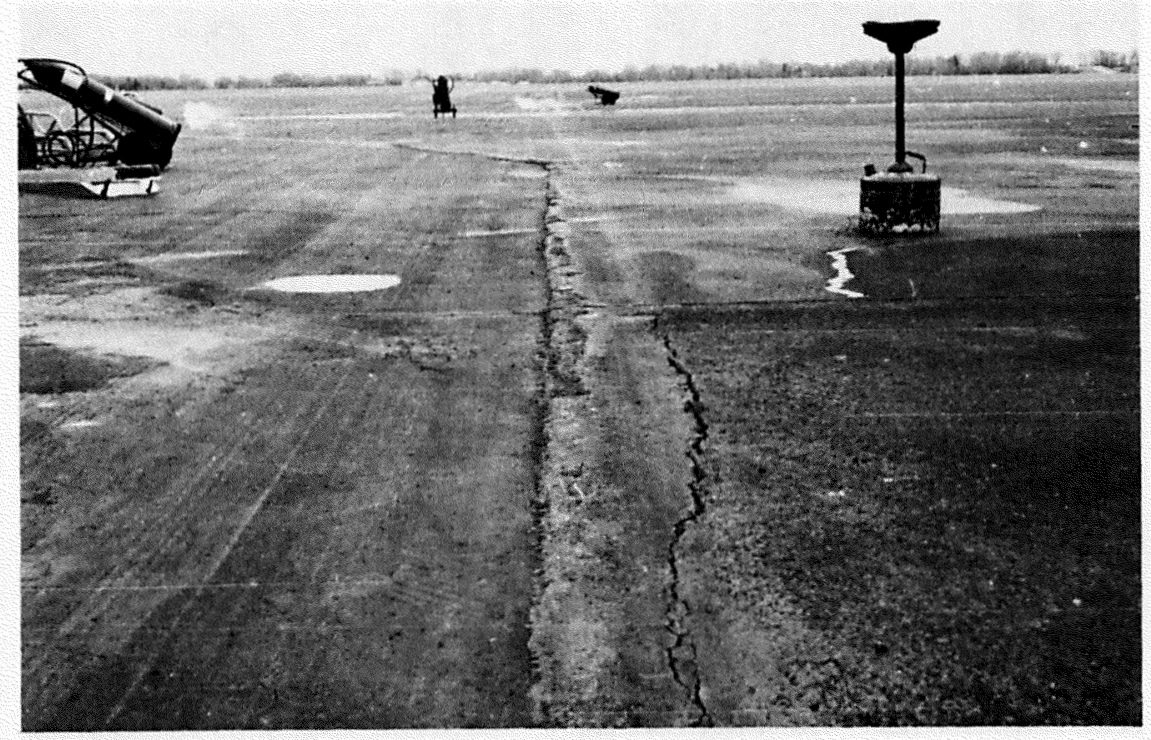

Photo 17. Tar-rubber constructed in 1971 on left and in 1964 on right; Selfridge AFB

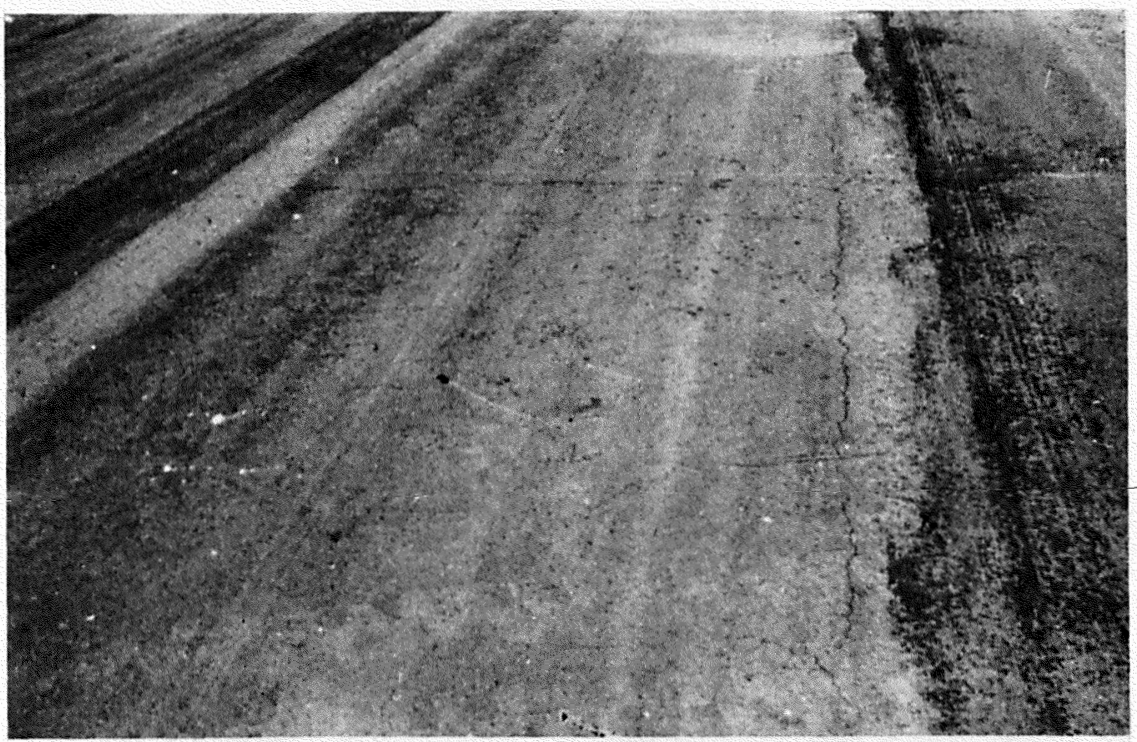

Photo 18. Forbes (1969) pavement surface sealed with a tar seal and a slurry 


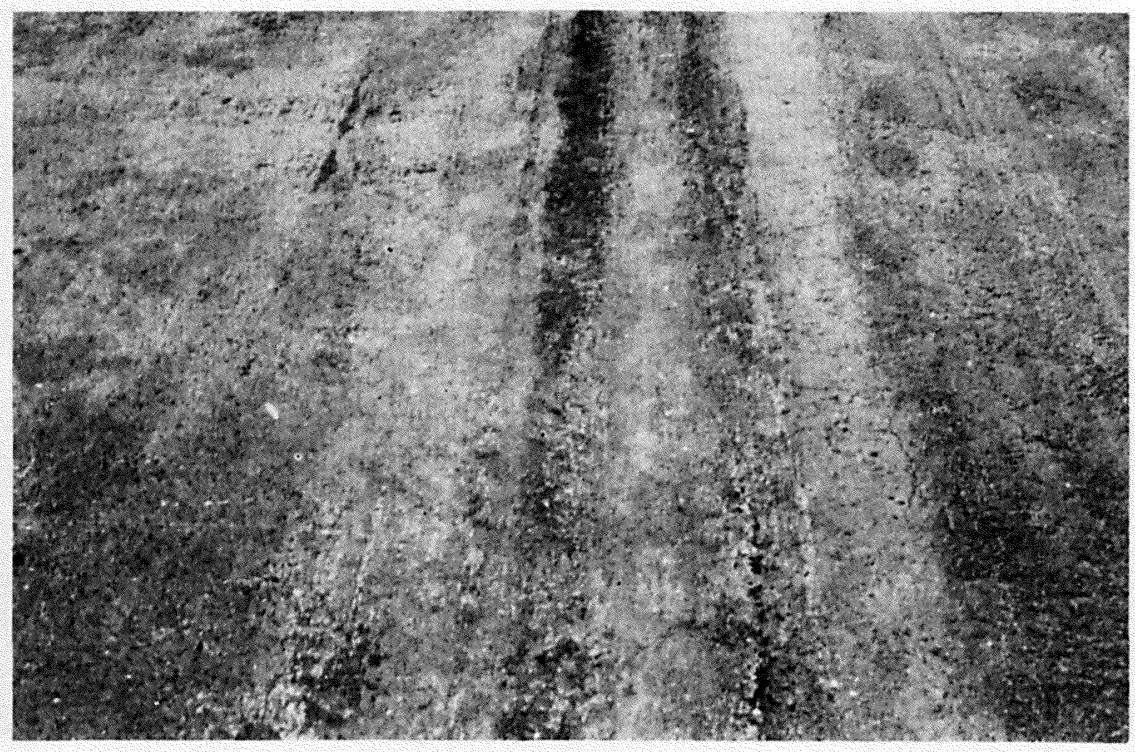

Photo 19. Forbes (1969) seal coat damaged from fuel spillage

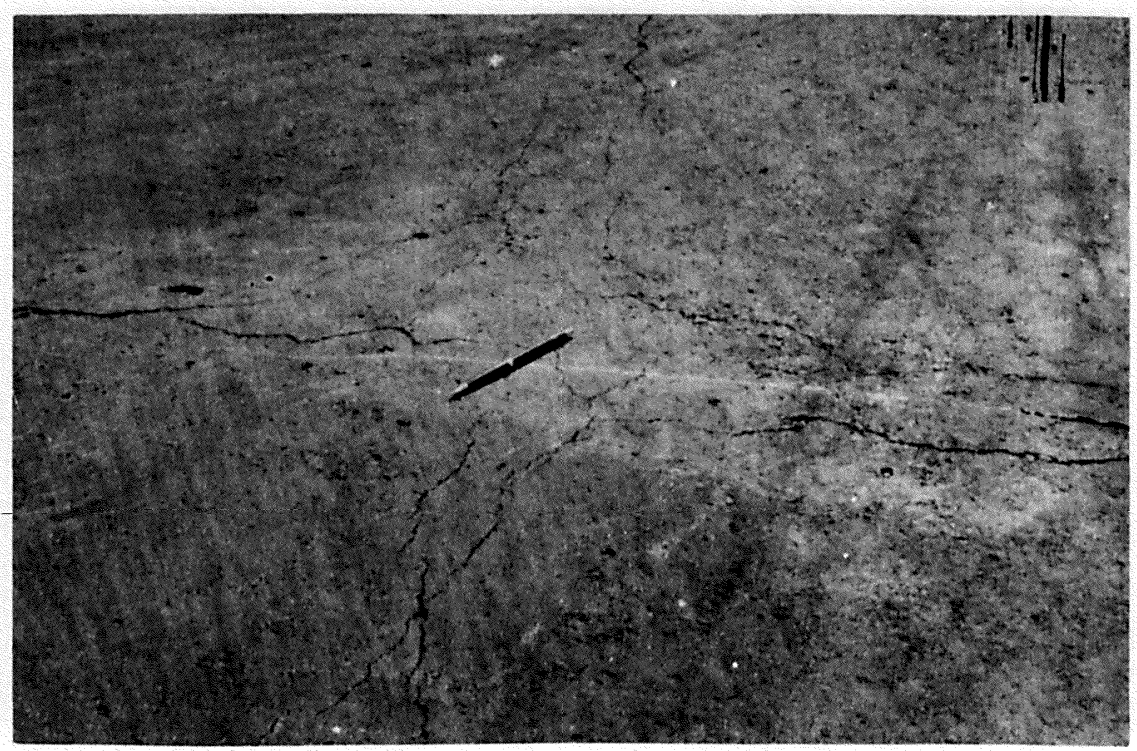

Photo 20. Reflection and random cracking in surface of Forbes (1971) pavement 


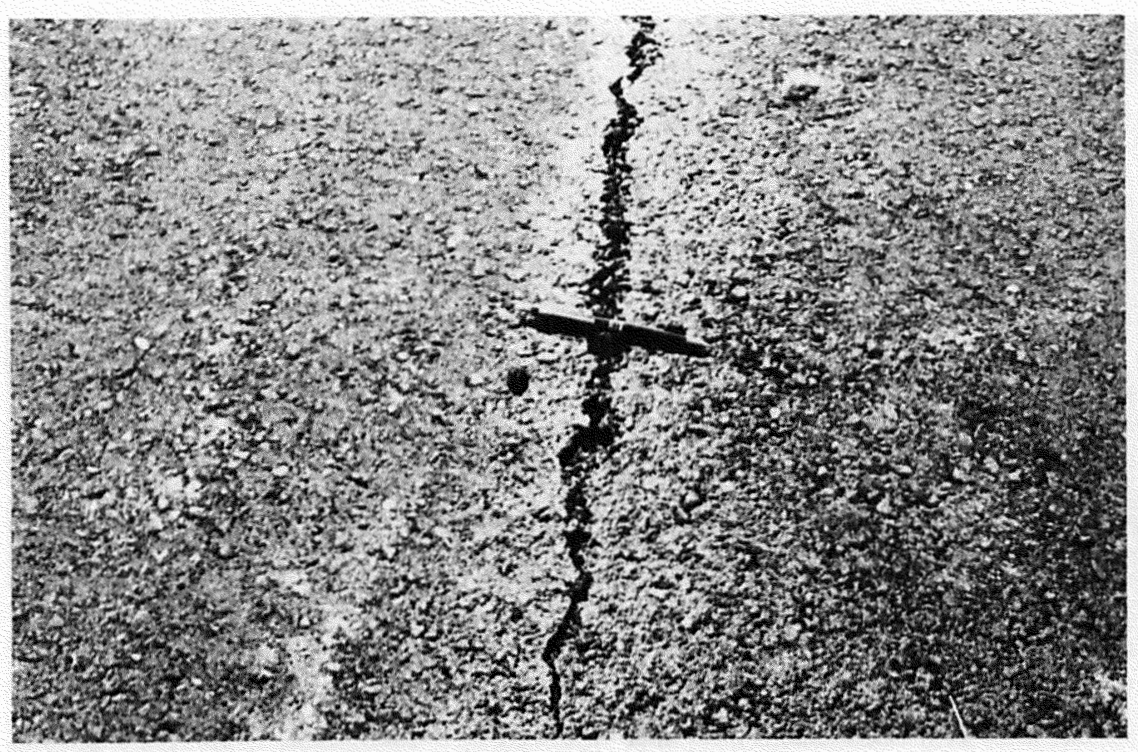

Photo 21. Reflection crack in Forbes (1972) pavement with water seeping from crack

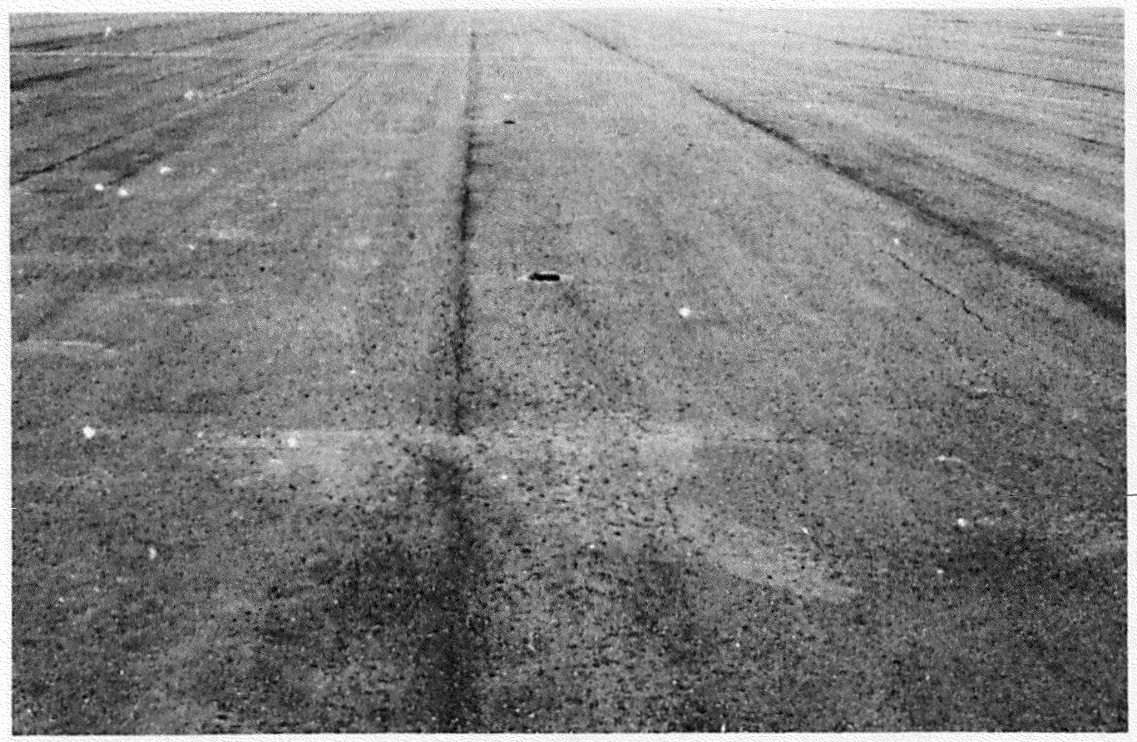

Photo 22. Paving joints beginning to open in Forbes (1972) pavement 


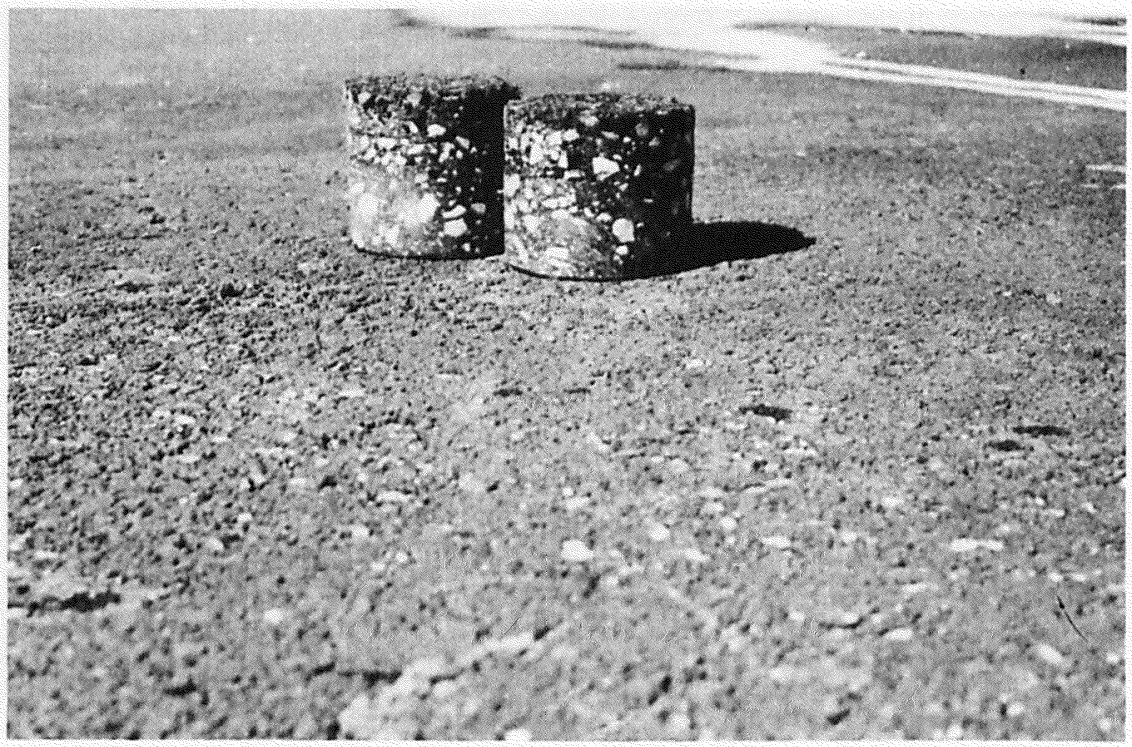

Photo 23. Cores taken out of Forbes (1972) tar-rubber and tar binder (Note large voids in surface course.)

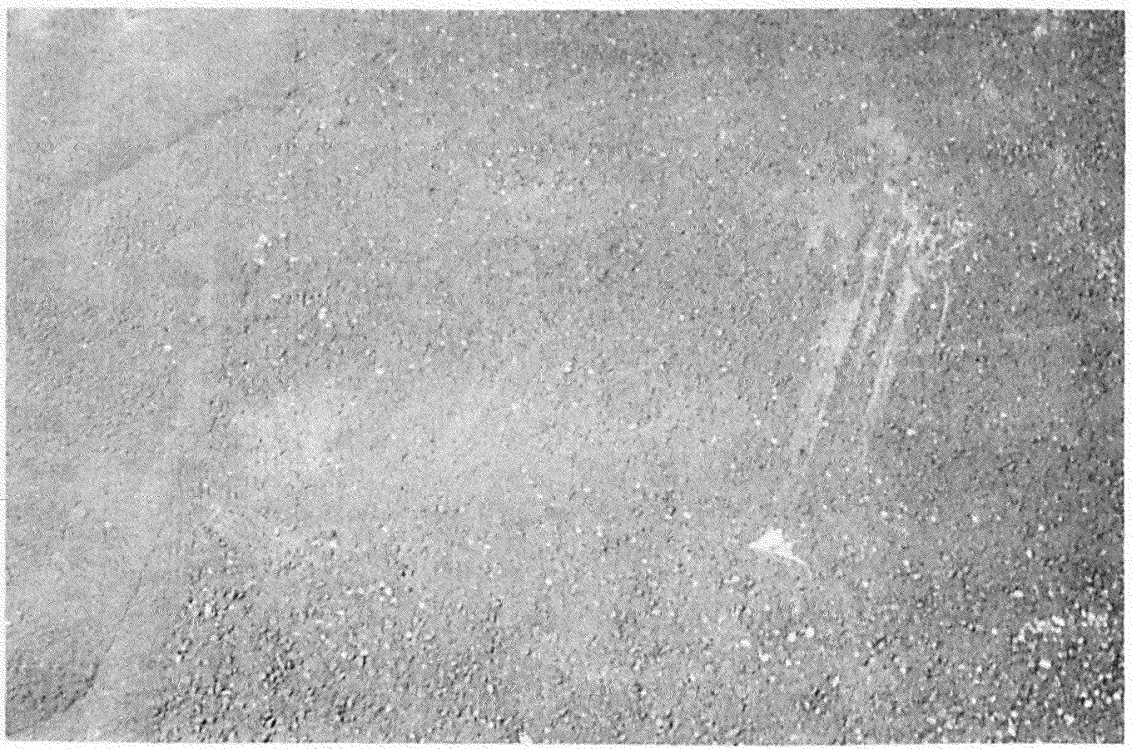

Photo 24. Surface texture of Forbes (1973) pavement 


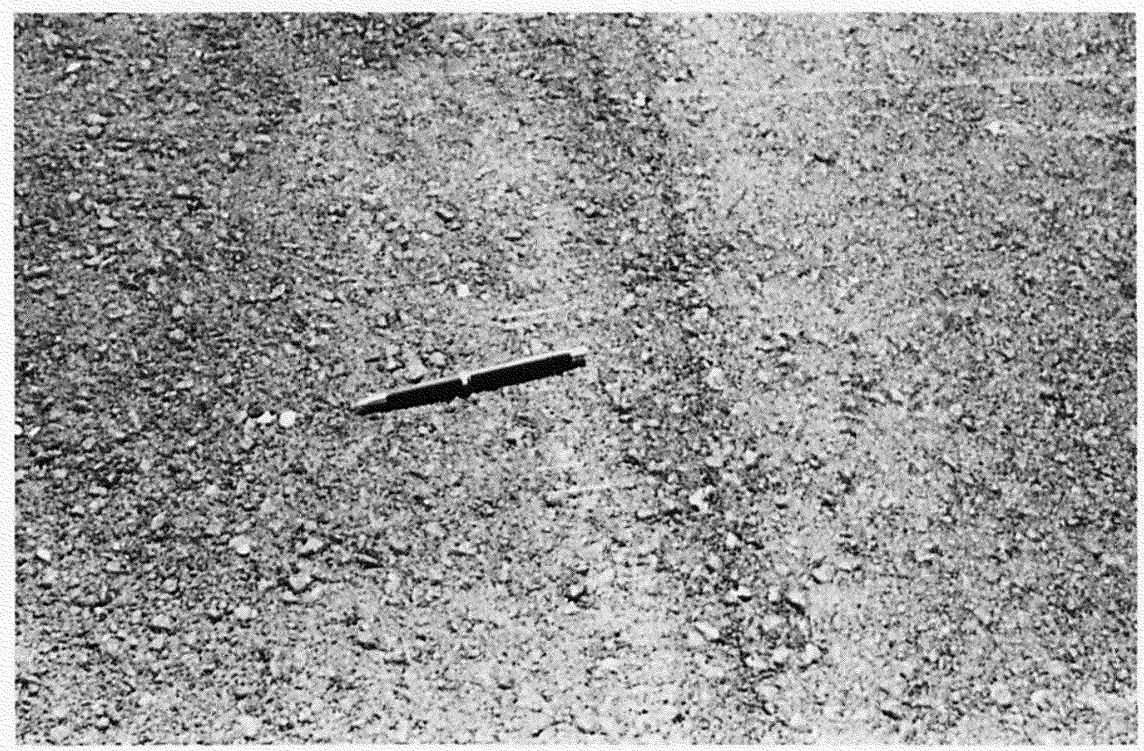

Photo 25. Forbes (1973) pavement condition at joint

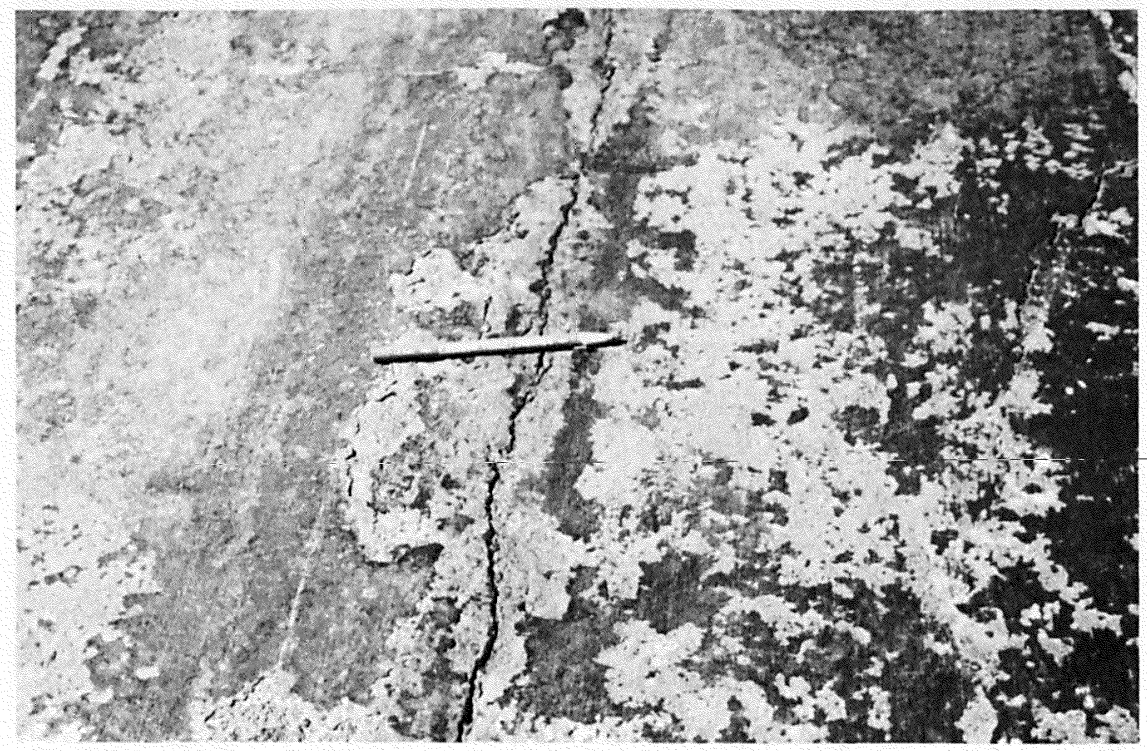

Photo 26. Surface seal deterioration from fuel spillage on Mountain Home (1968) pavement 


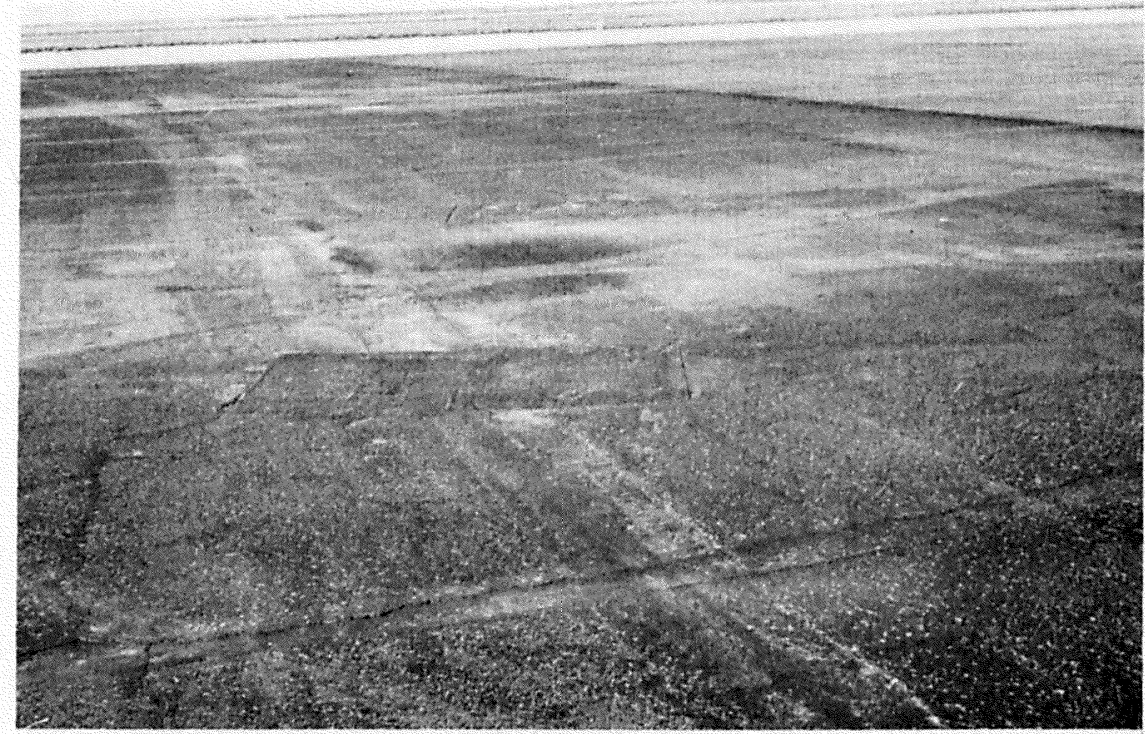

Photo 27. Damaged Mountain Home (1968) pavement and areas subsequently replaced with PCC. Damage was caused by parked $\mathrm{F}-4$ aircraft wheels

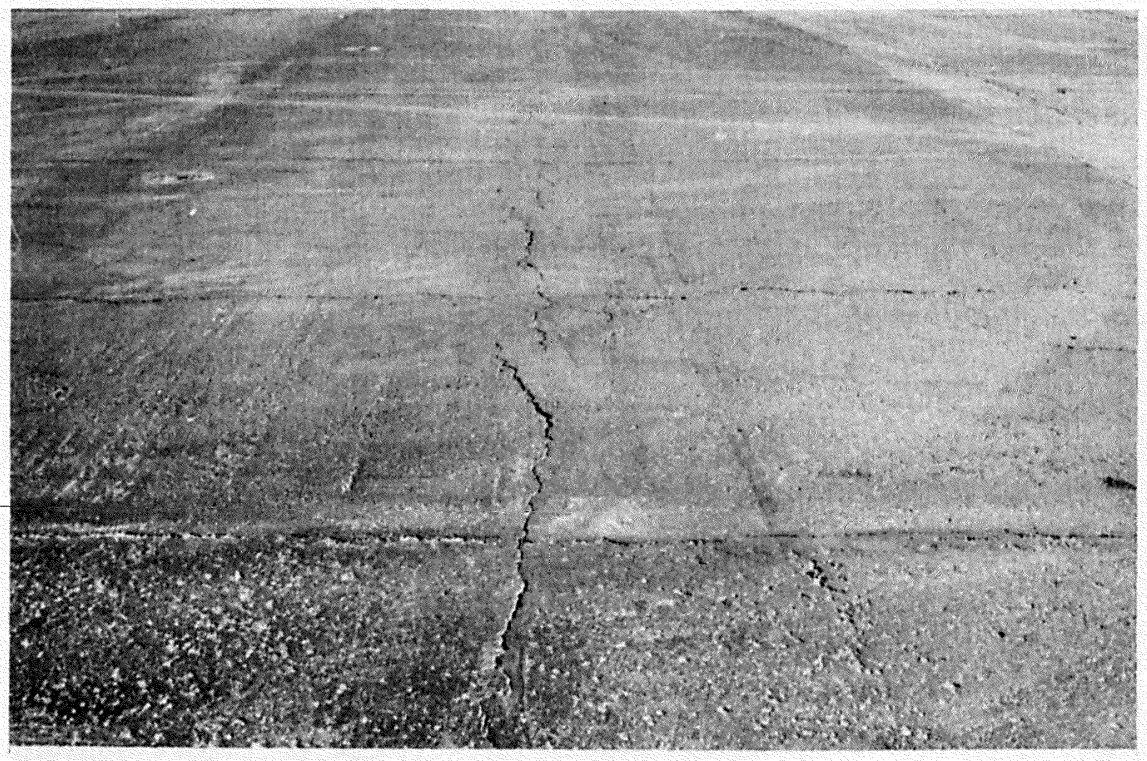

Photo 28. Reflection cracks in asphalt in foreground continuing through tar-rubber area where roofing felt was used in Mountain Home (1968) pavement 


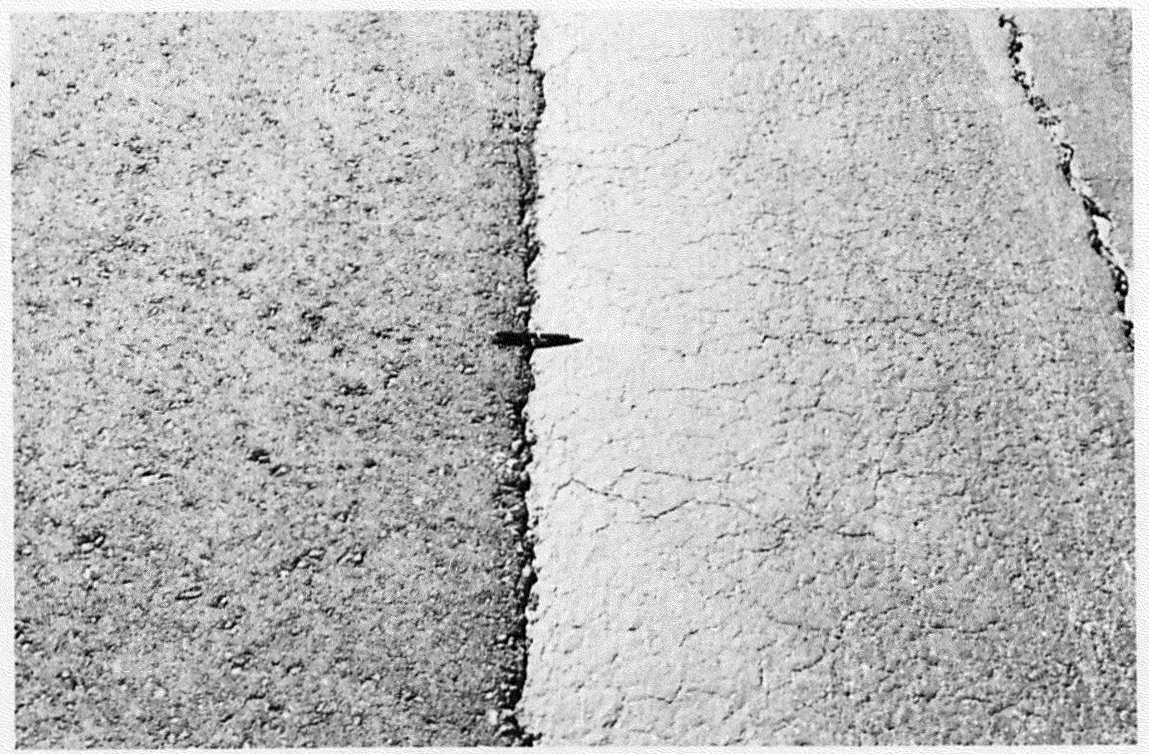

Photo 29. Surface texture of Mountain Home (1970) pavements; tar-rubber on left and asphaltic concrete on right

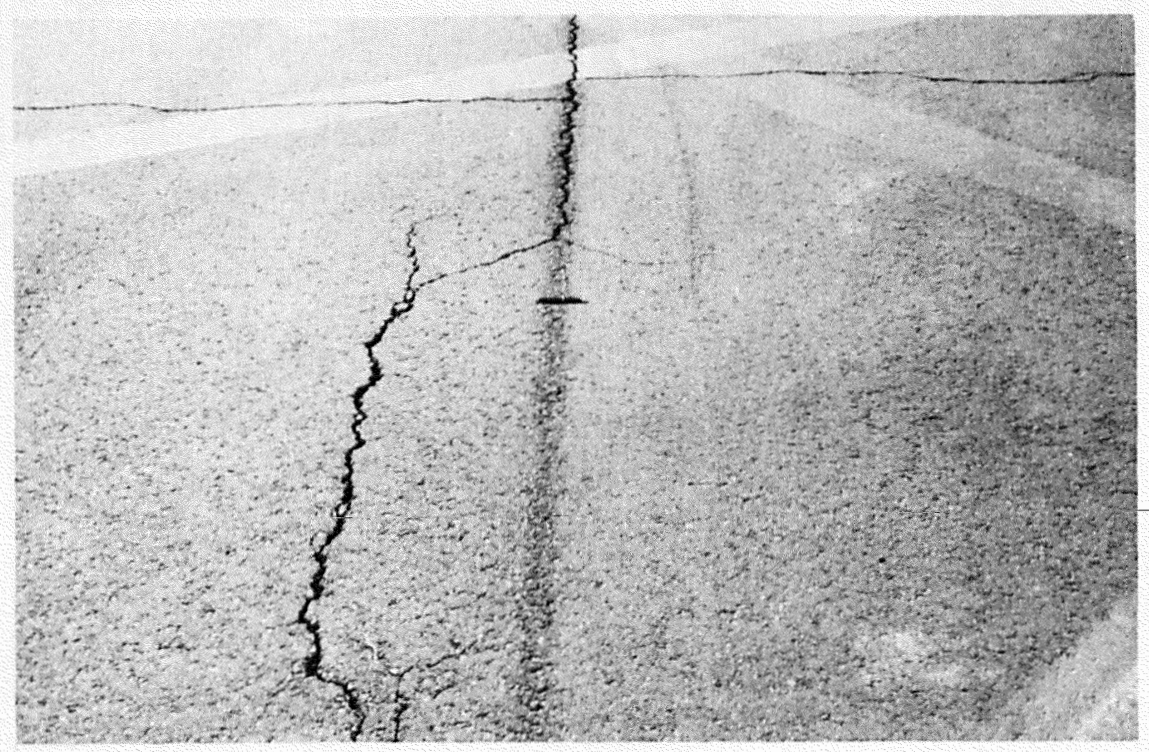

Photo 30. Reflection cracking and cracking in construction joint of Mountain Home (1970) pavement 


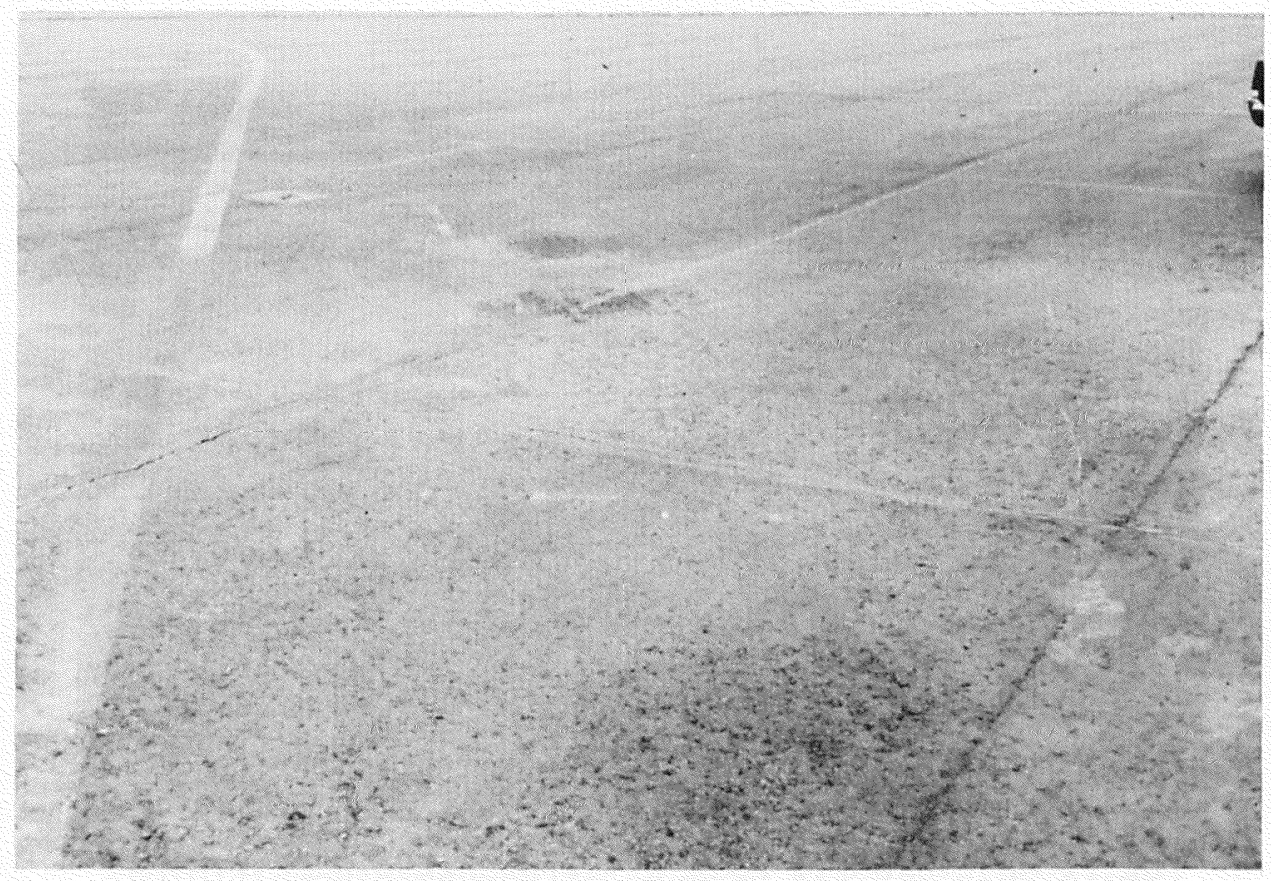

Photo 31. Fuel spillage damage on Langley (1966) pavement, with some loss of surface fines

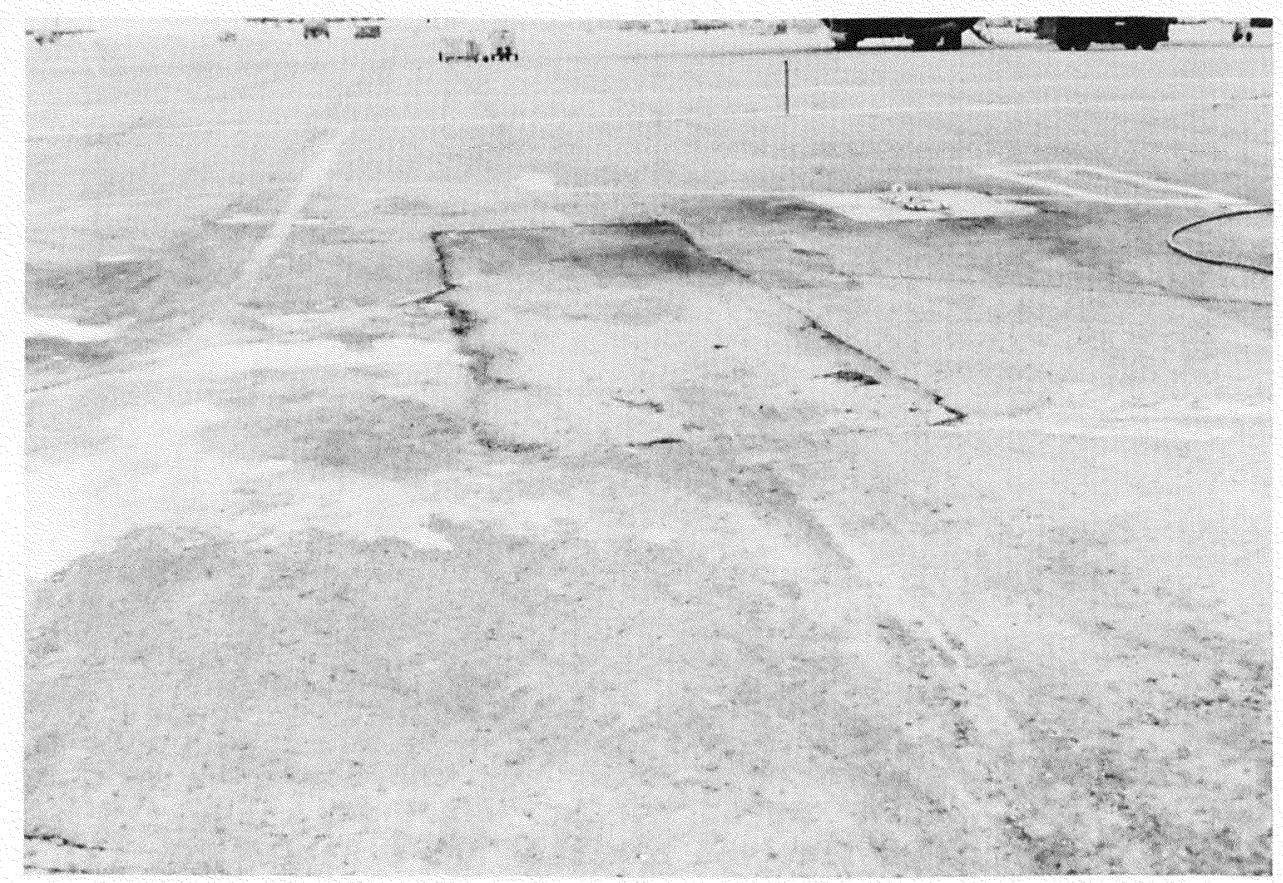

Photo 32. General deterioration in Langley (1966) fighter aircraft parking area 
Photo 33. Langley (1969) pavement in good condition but with some joints beginning to open

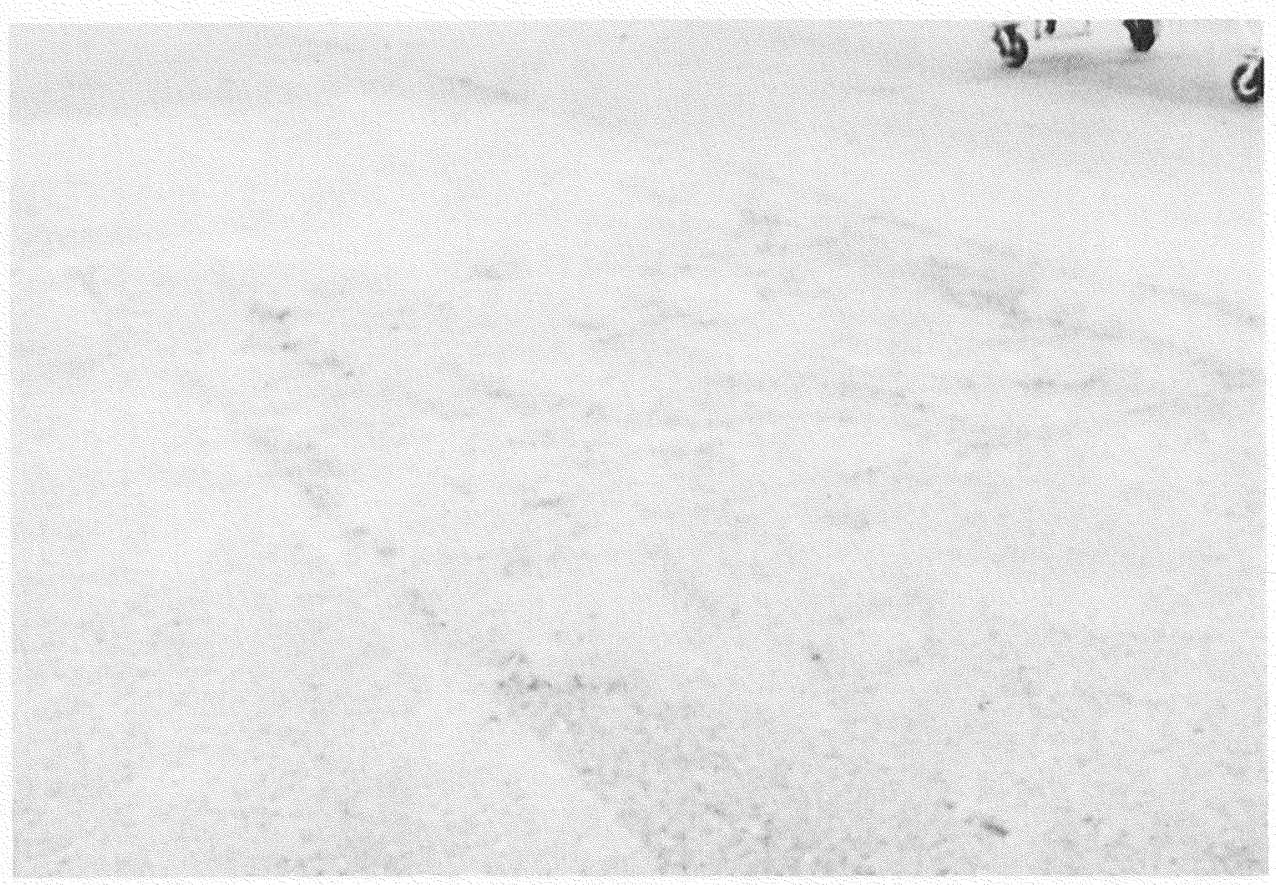

Photo 34. Open surface texture created during construction of Langley (1971) pavement 


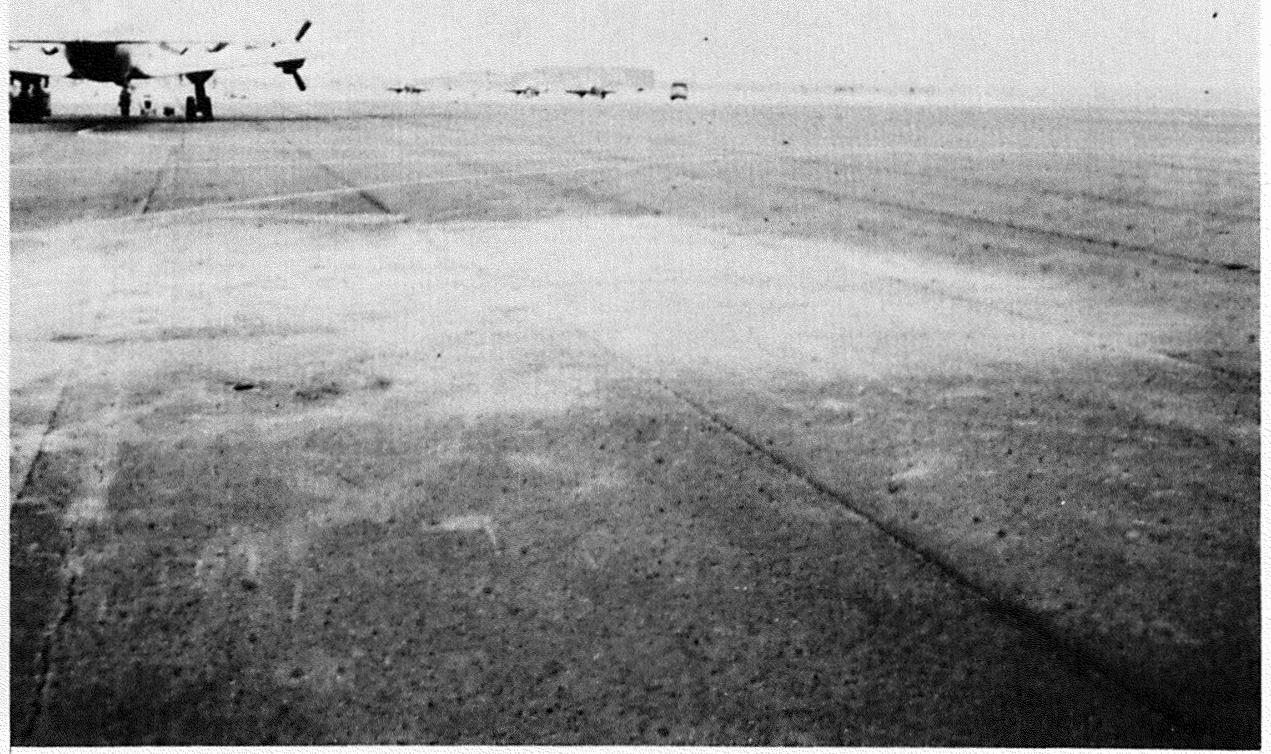

Photo 35. Considerable amount of fuel stains and minor amount of deterioration in Langley (1971) pavement

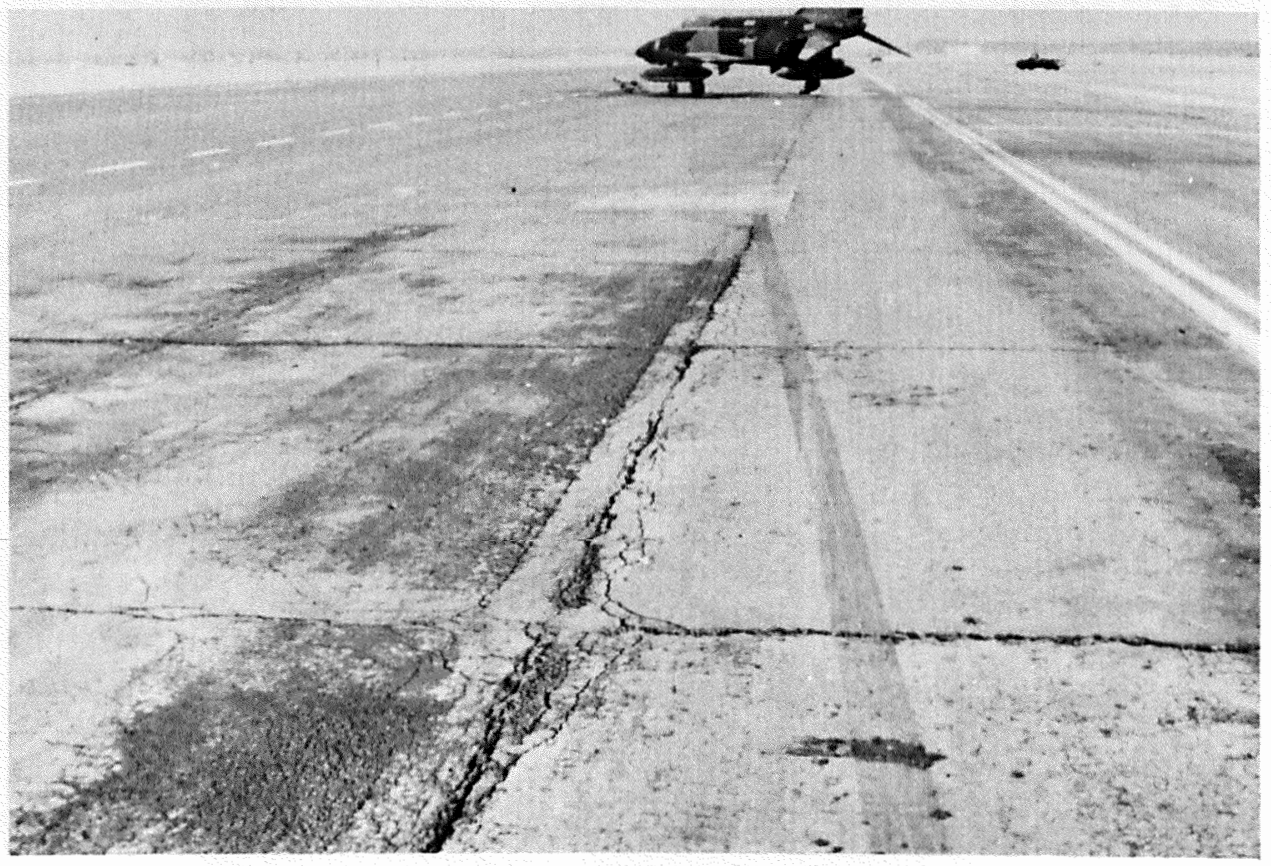

Photo 36. Outer edge of Wright-Patterson (1960) taxiway 8 used for parking of aircraft 


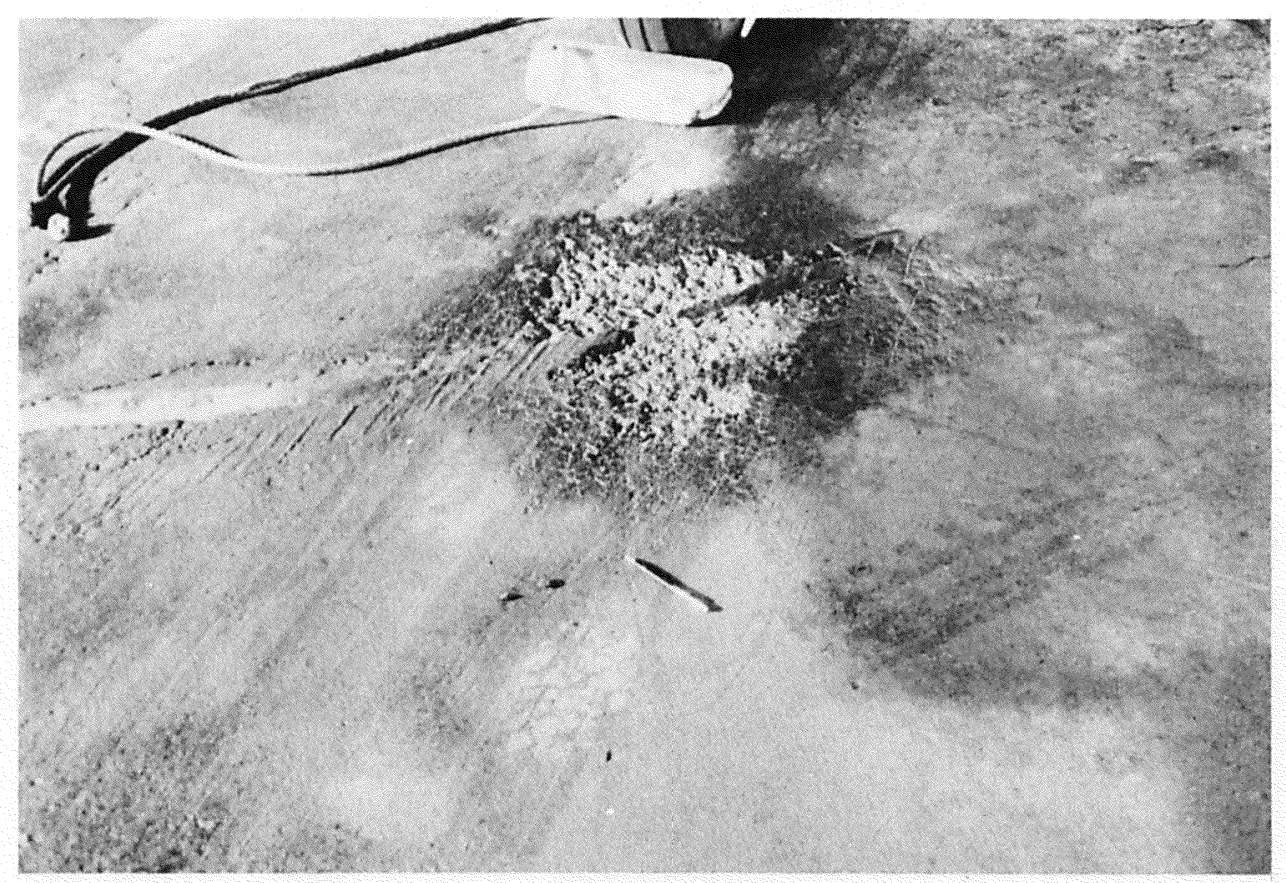

Photo 37. Deterioration in Wright-Patterson (1962-63) pavement from fuel and hydraulic fluid spillage

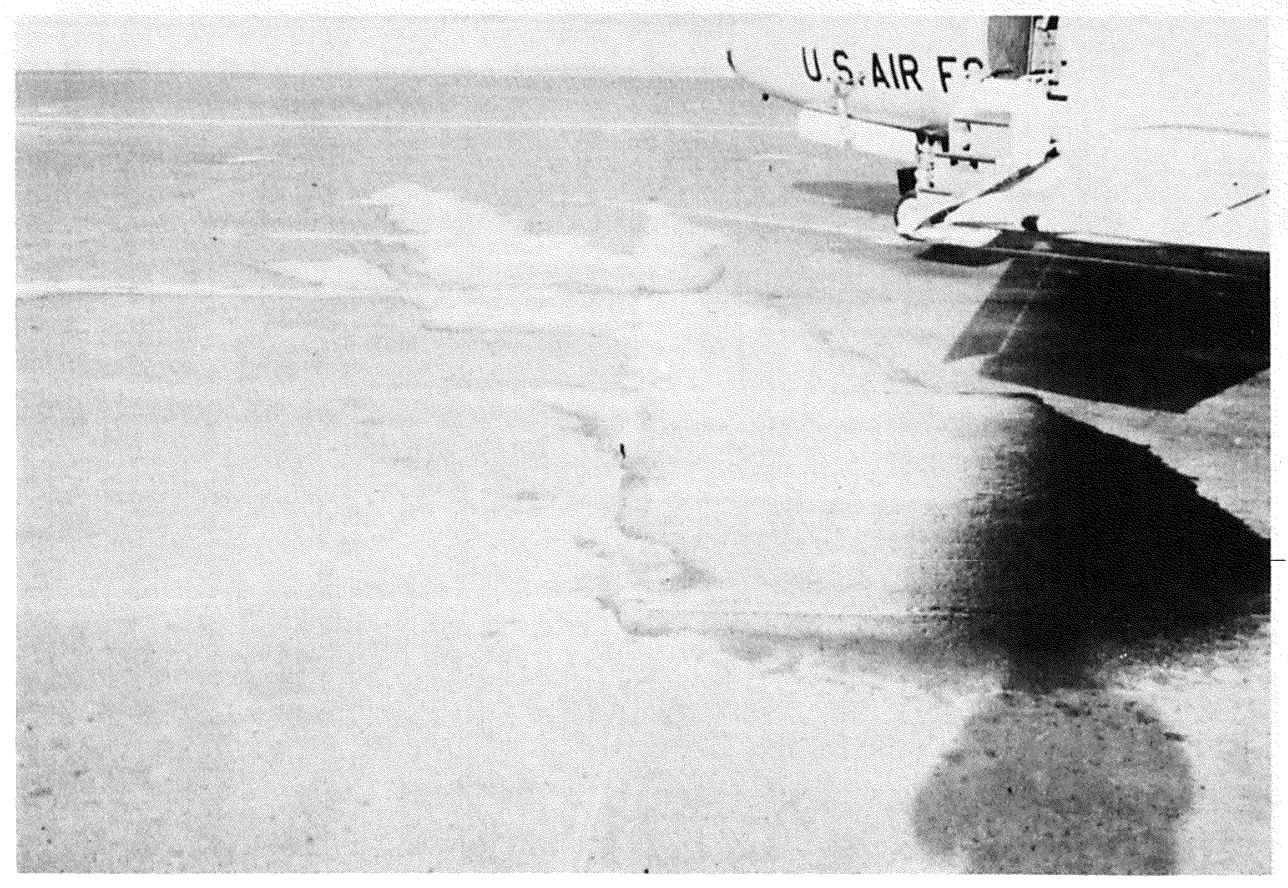

Photo 38. Poor housekeeping; excessive fuel spillage on Wright-Patterson (1962-63) pavement 


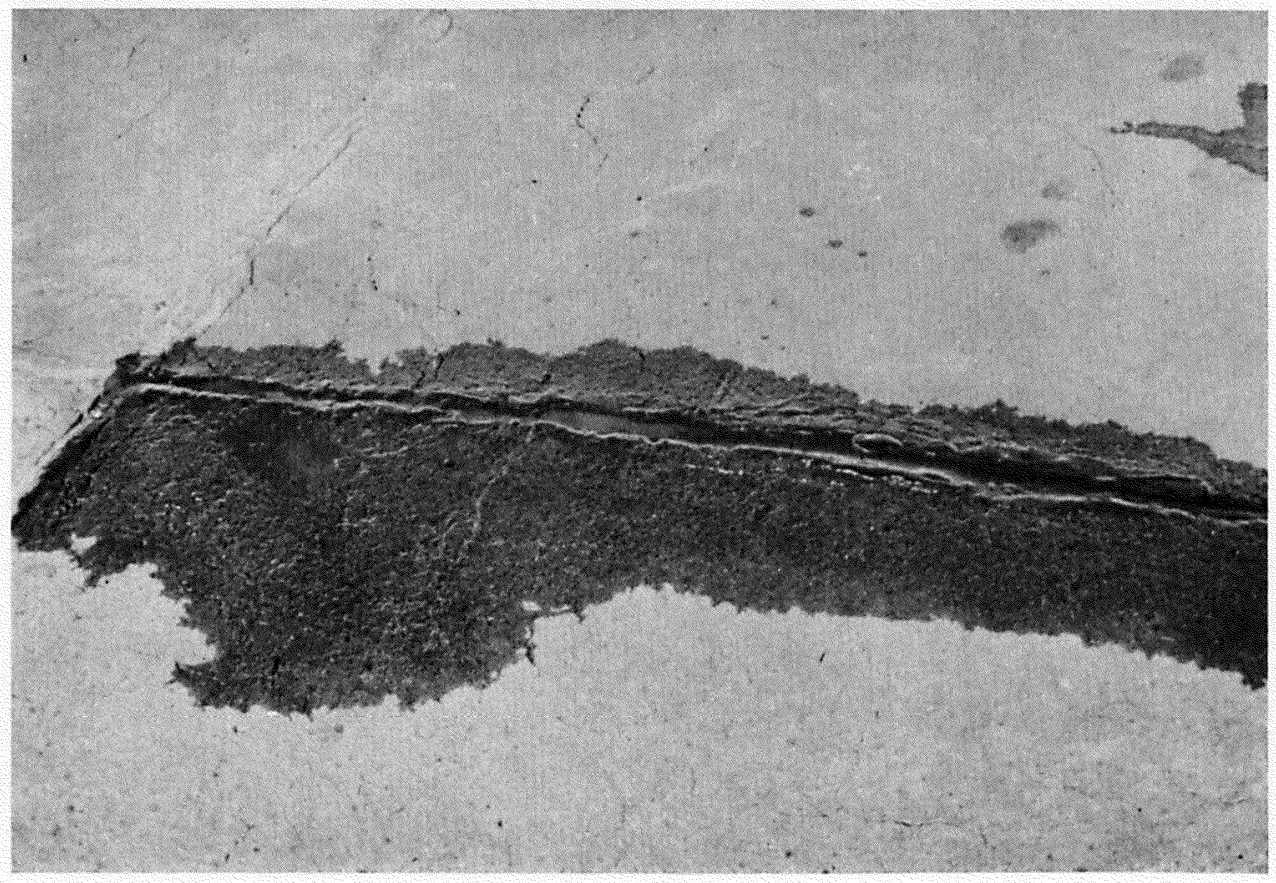

Photo 39. Fuel spillage running down reflection crack in Wright-Patterson (1962-63) pavement

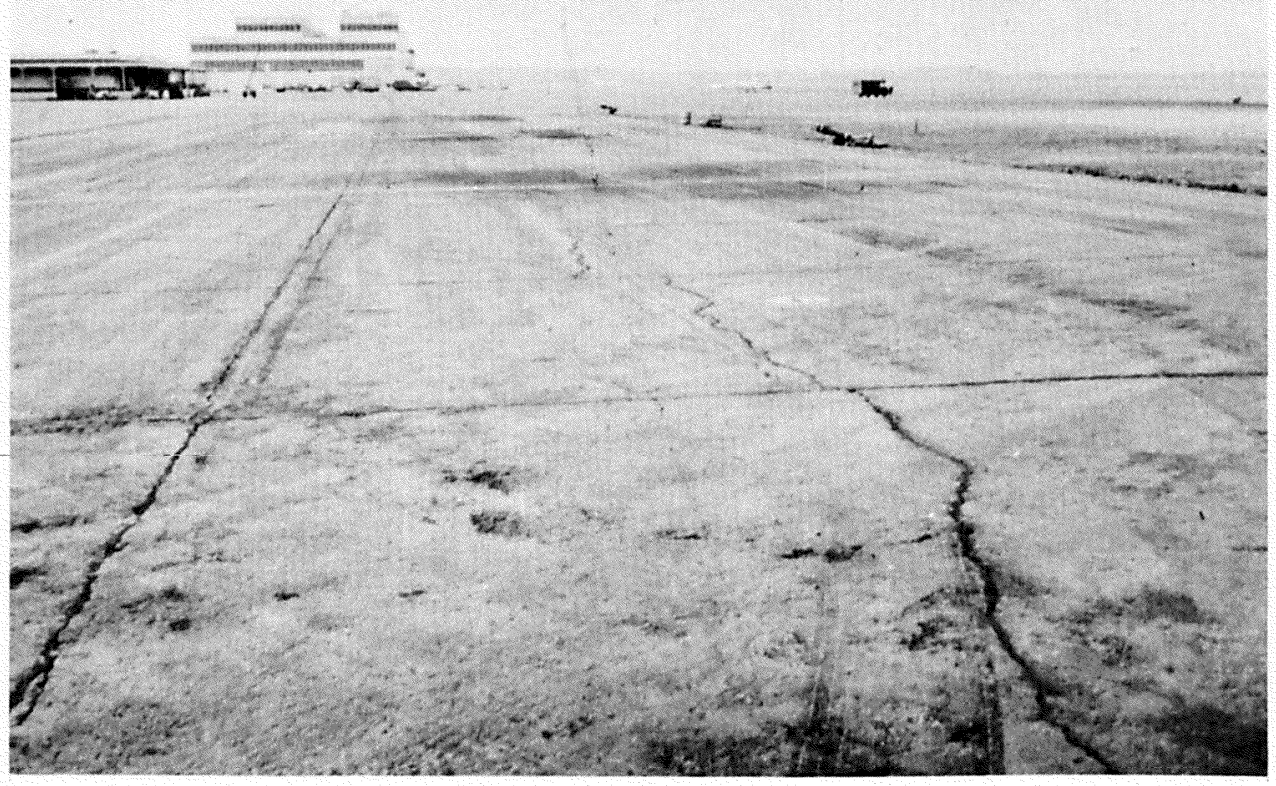

Photo 40. General deterioration of Wright-Patterson (1966) pavement from cracking and fuel spillage 


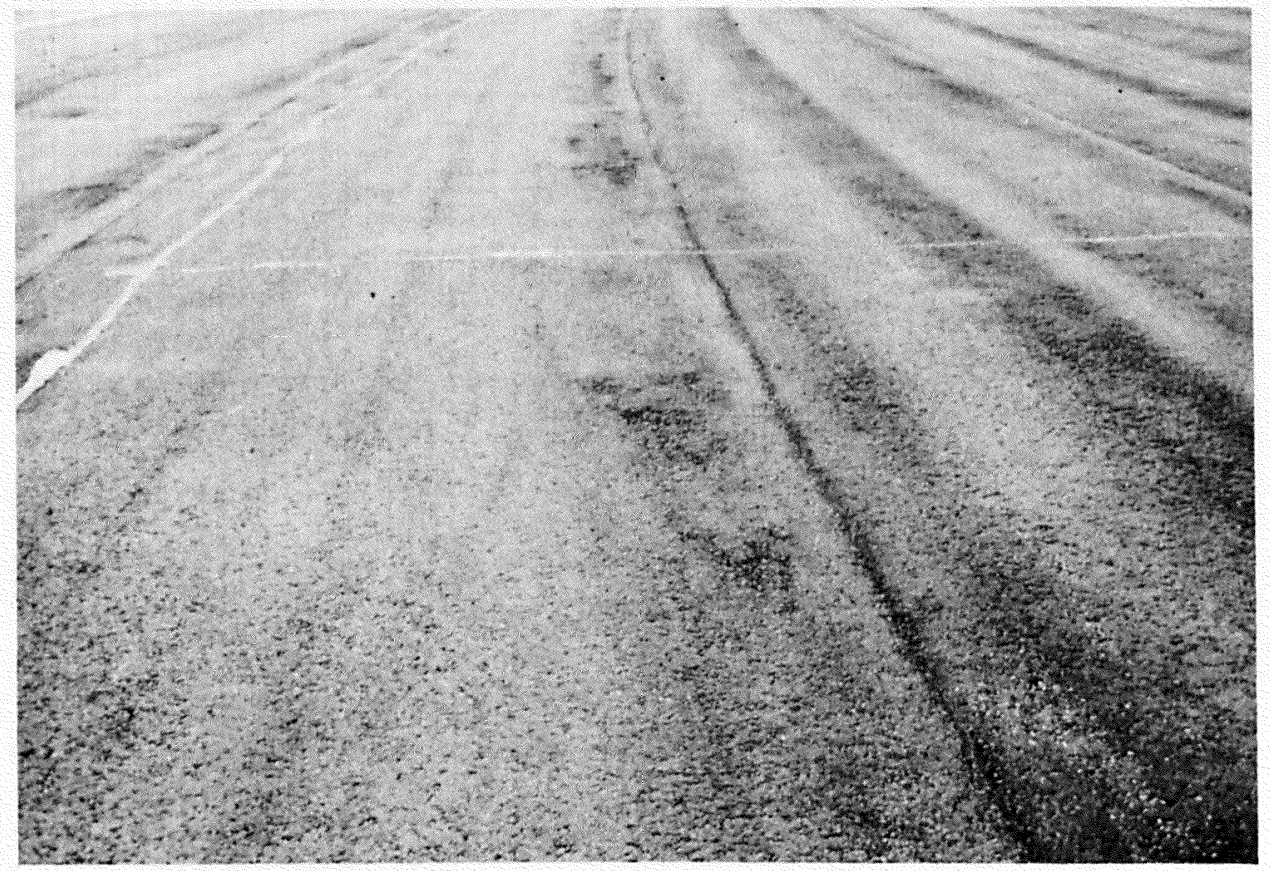

Photo 41. Poor construction on Wright-Patterson (1970) warmup apron 


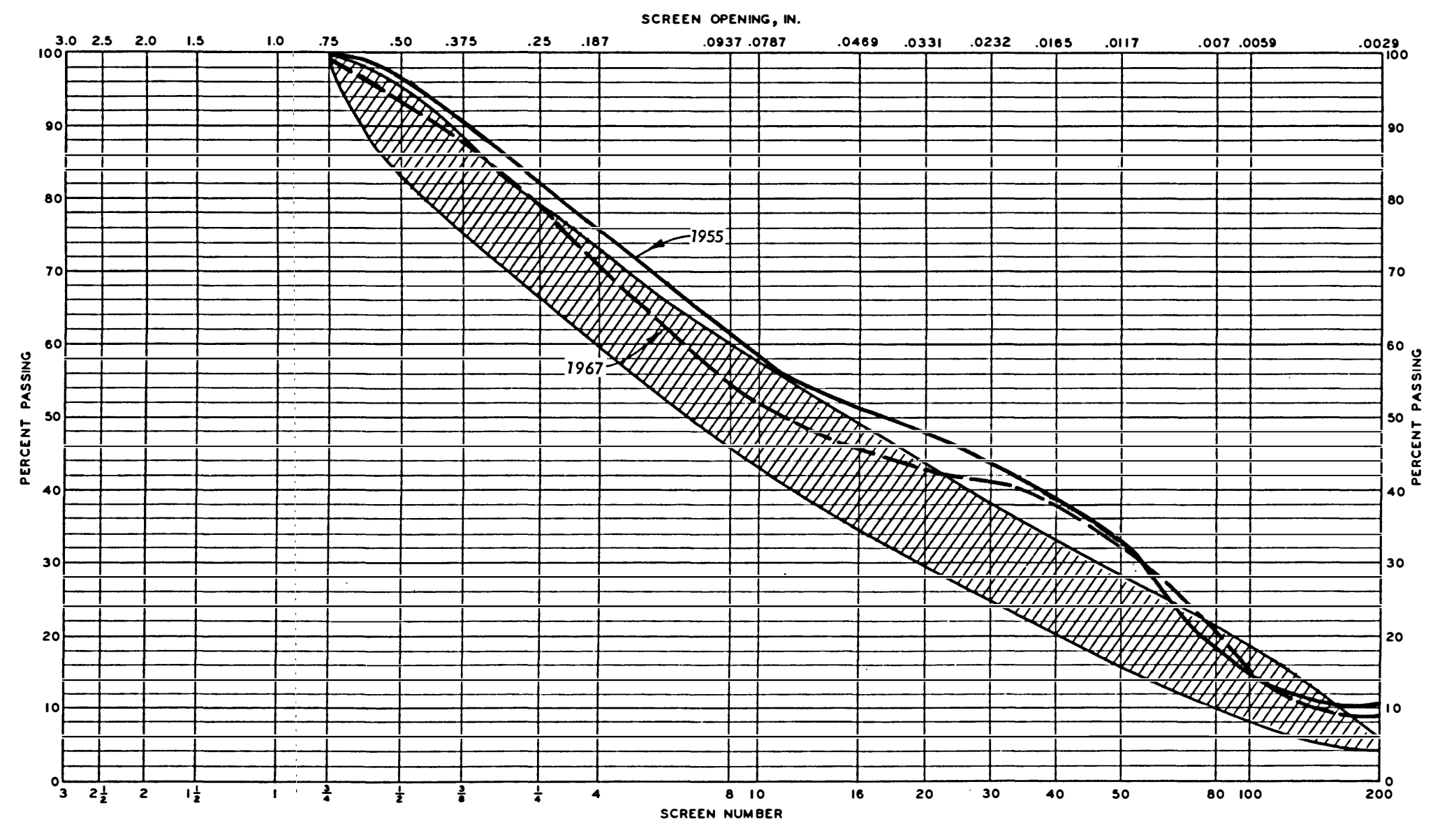




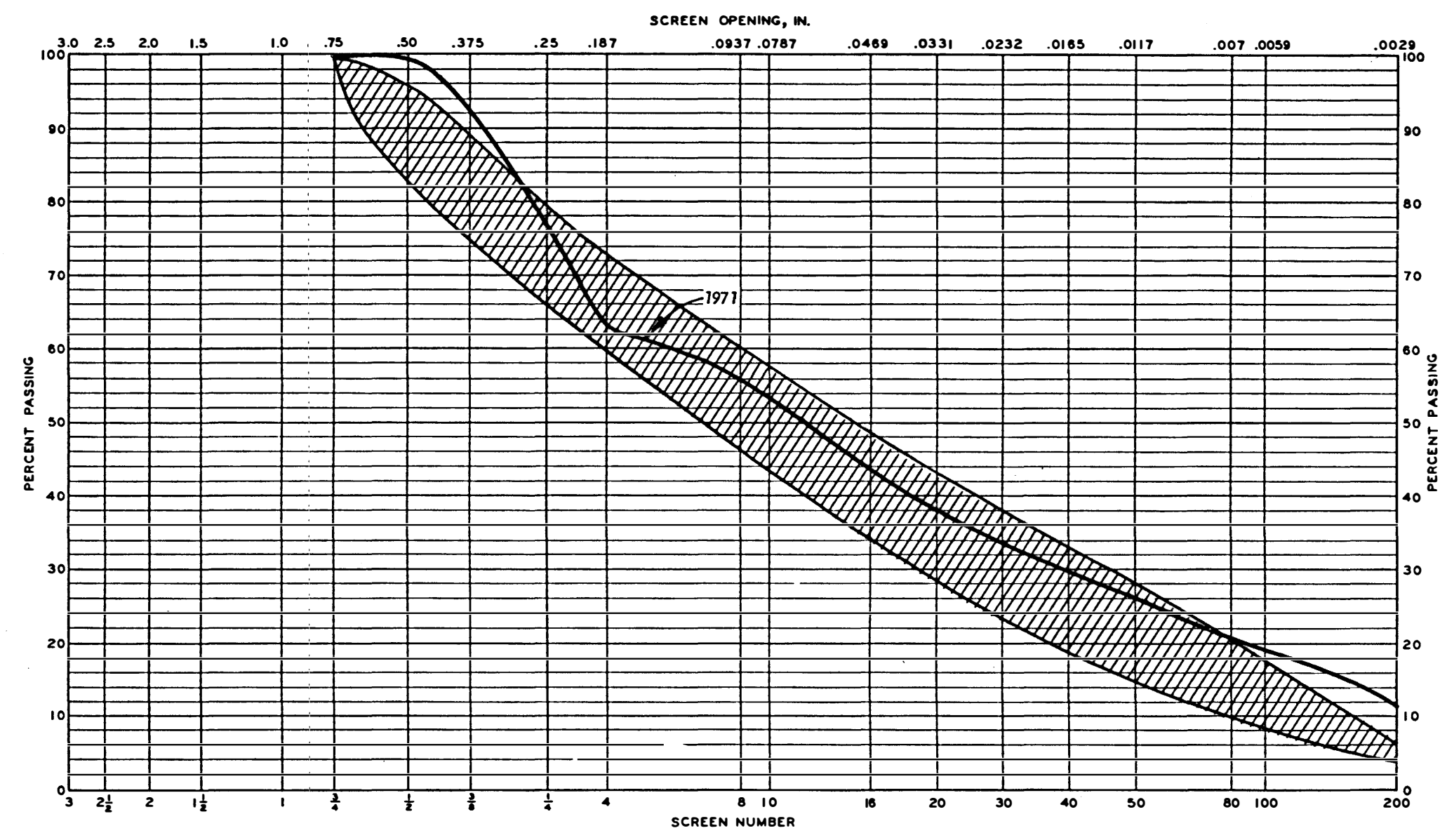

GRADATION OF TAR-RUBBER PAVEMENT MACDILL AFB 


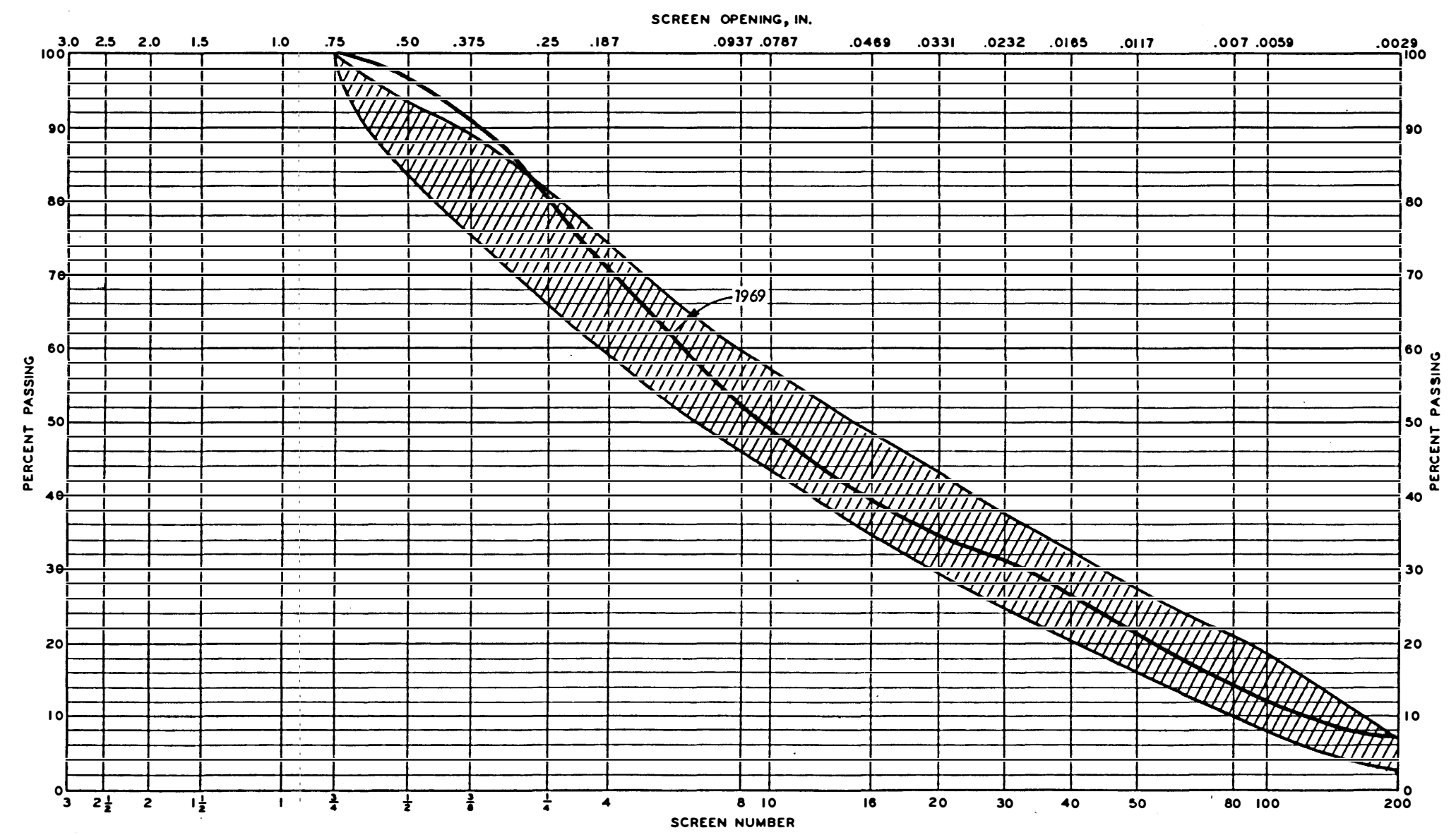


SCREEN OPENING, IN.

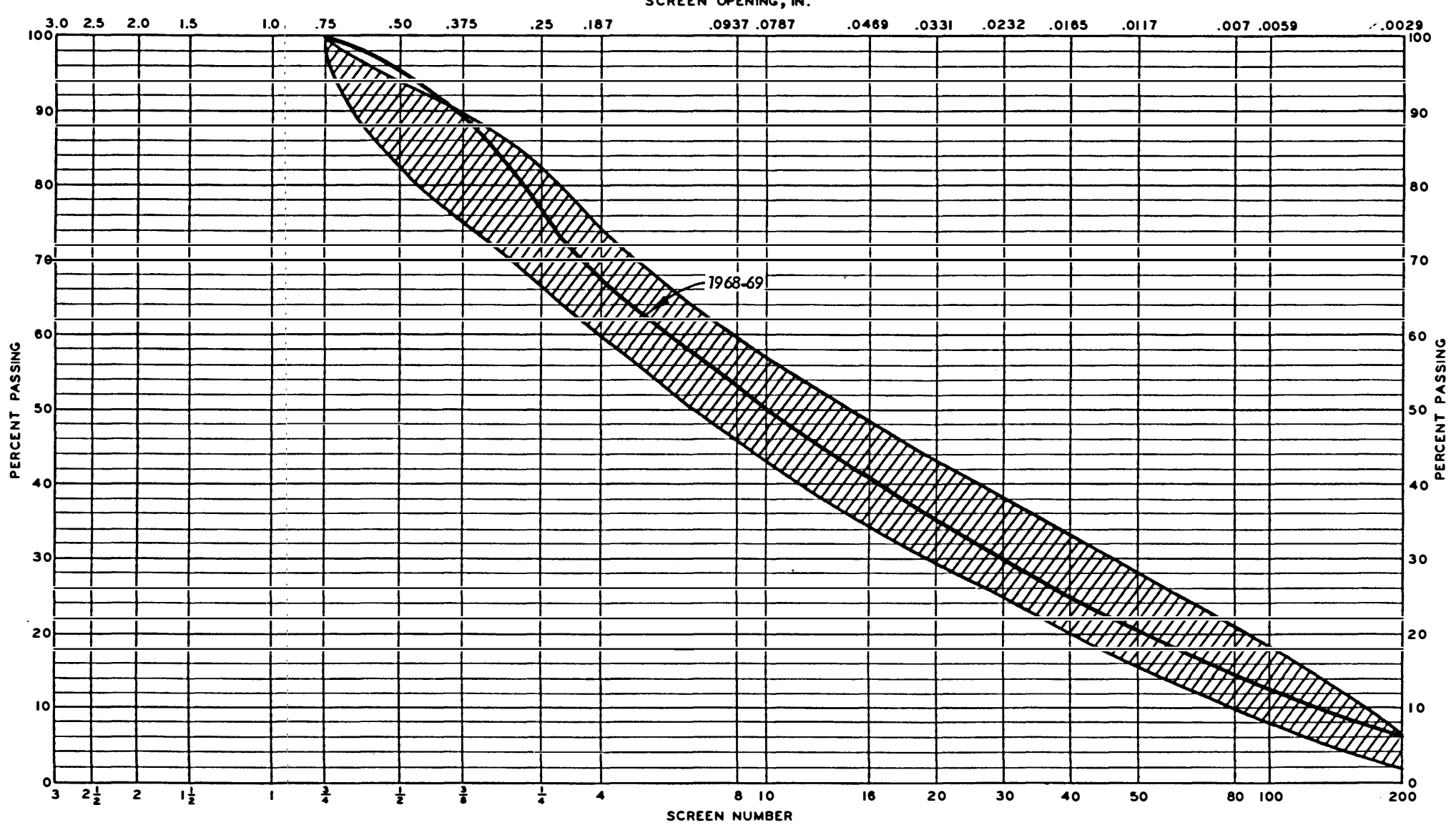

GRADATION OF TAR-RUBBER PAVEMENT POPE AFB 
SCREEN OPENING, IN.

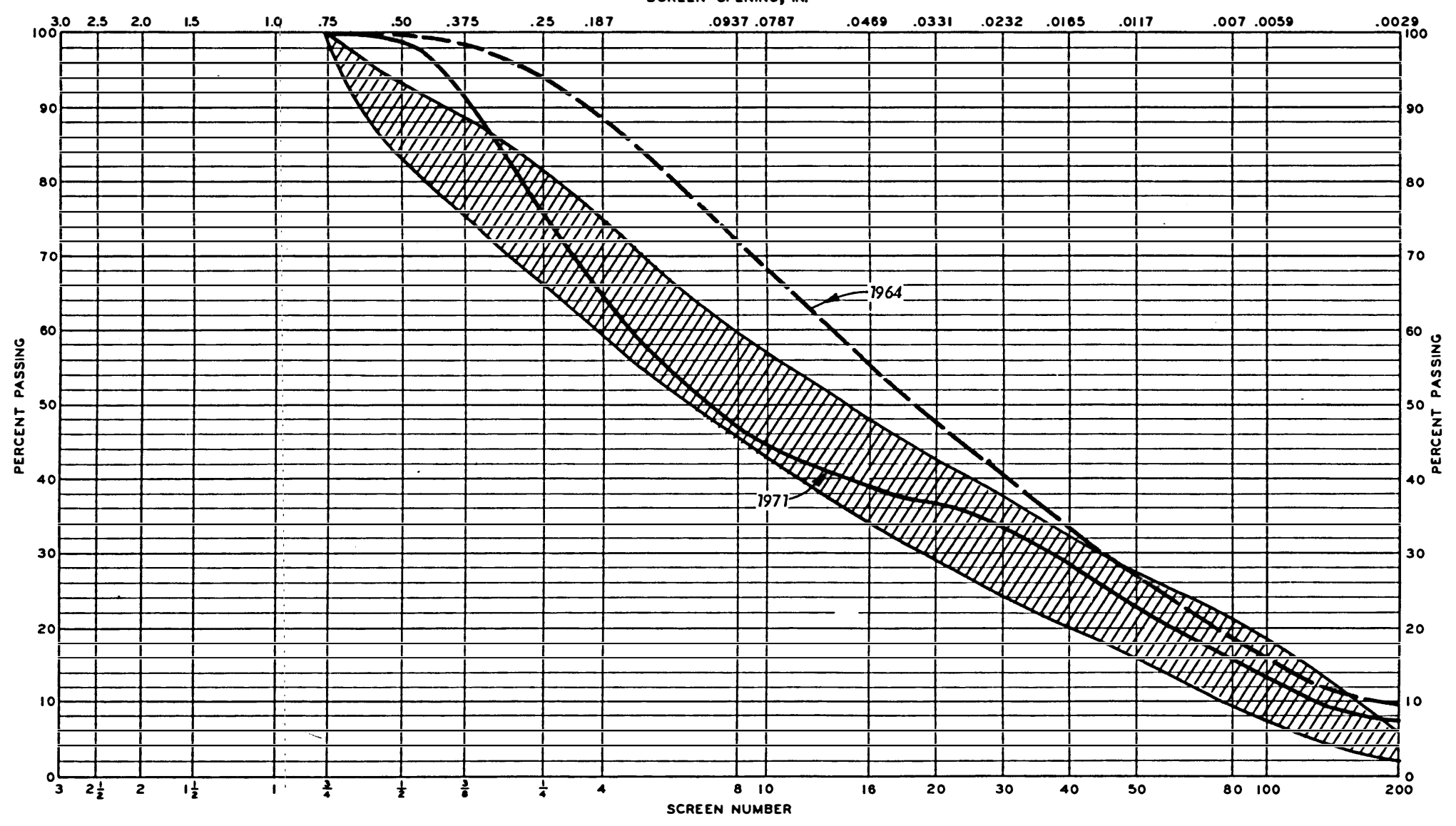


SCREEN OPENING, IN.

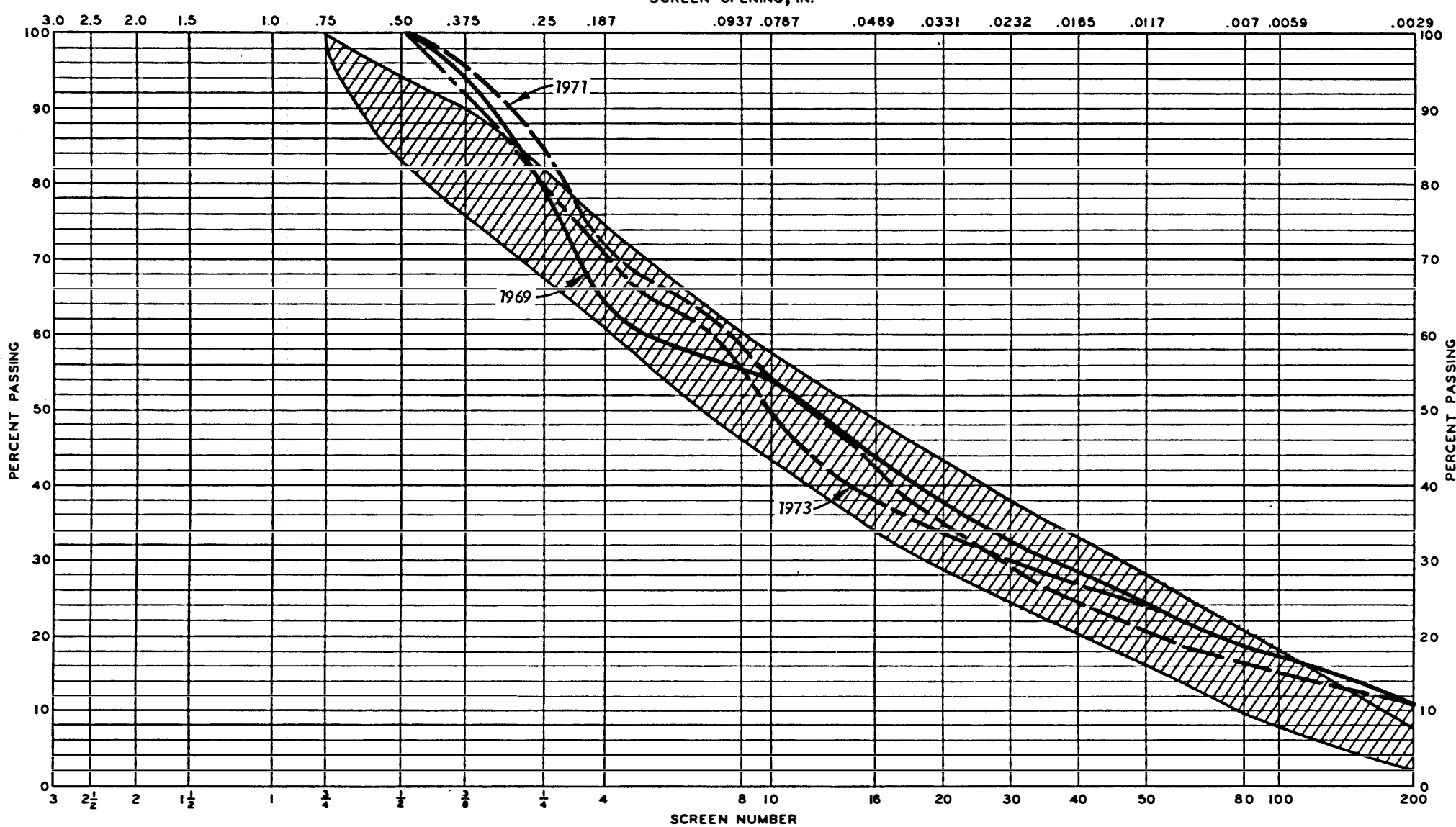

GRADATION OF TAR-RUBBER PAVEMENT FORBES AFB 


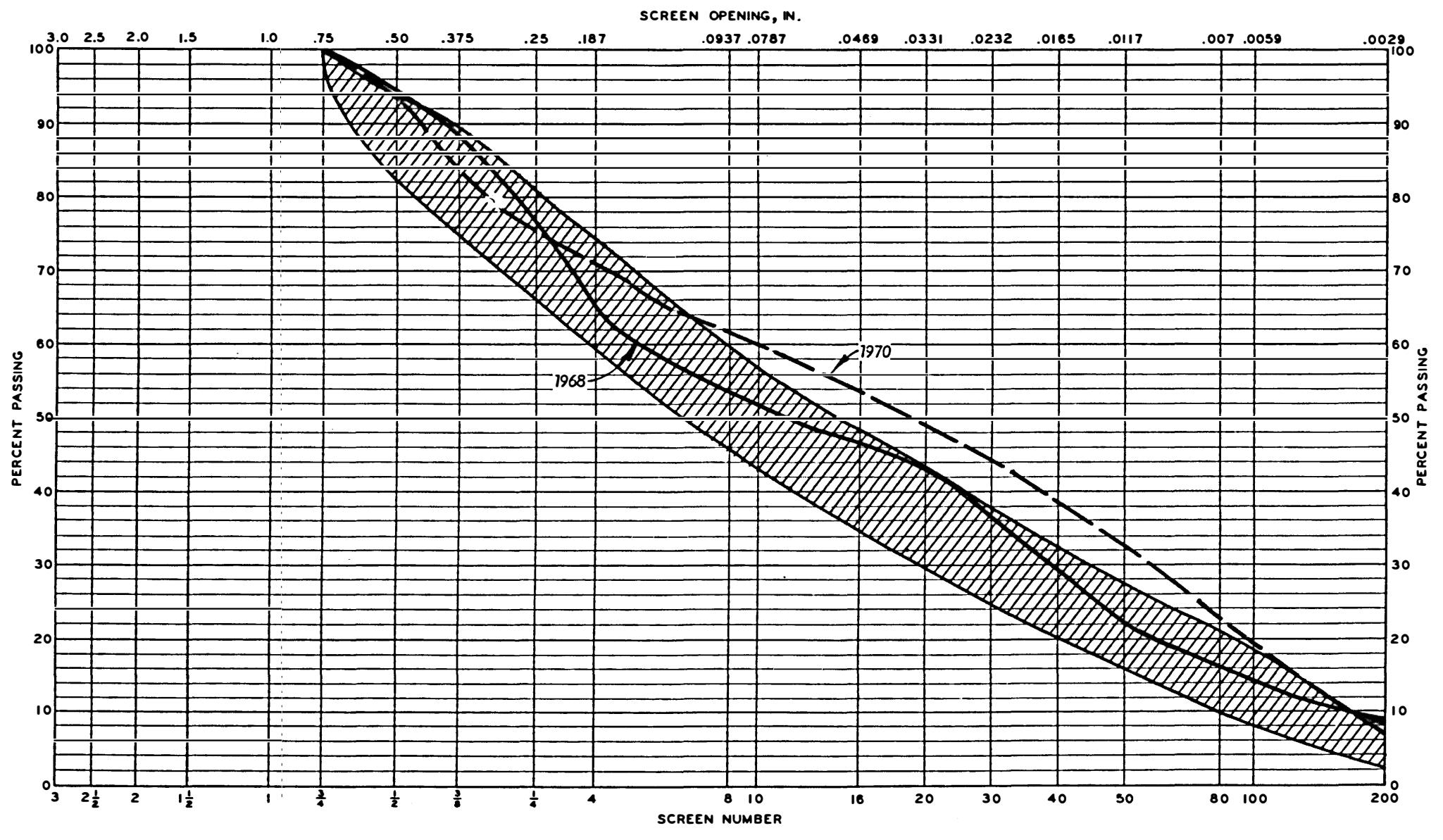




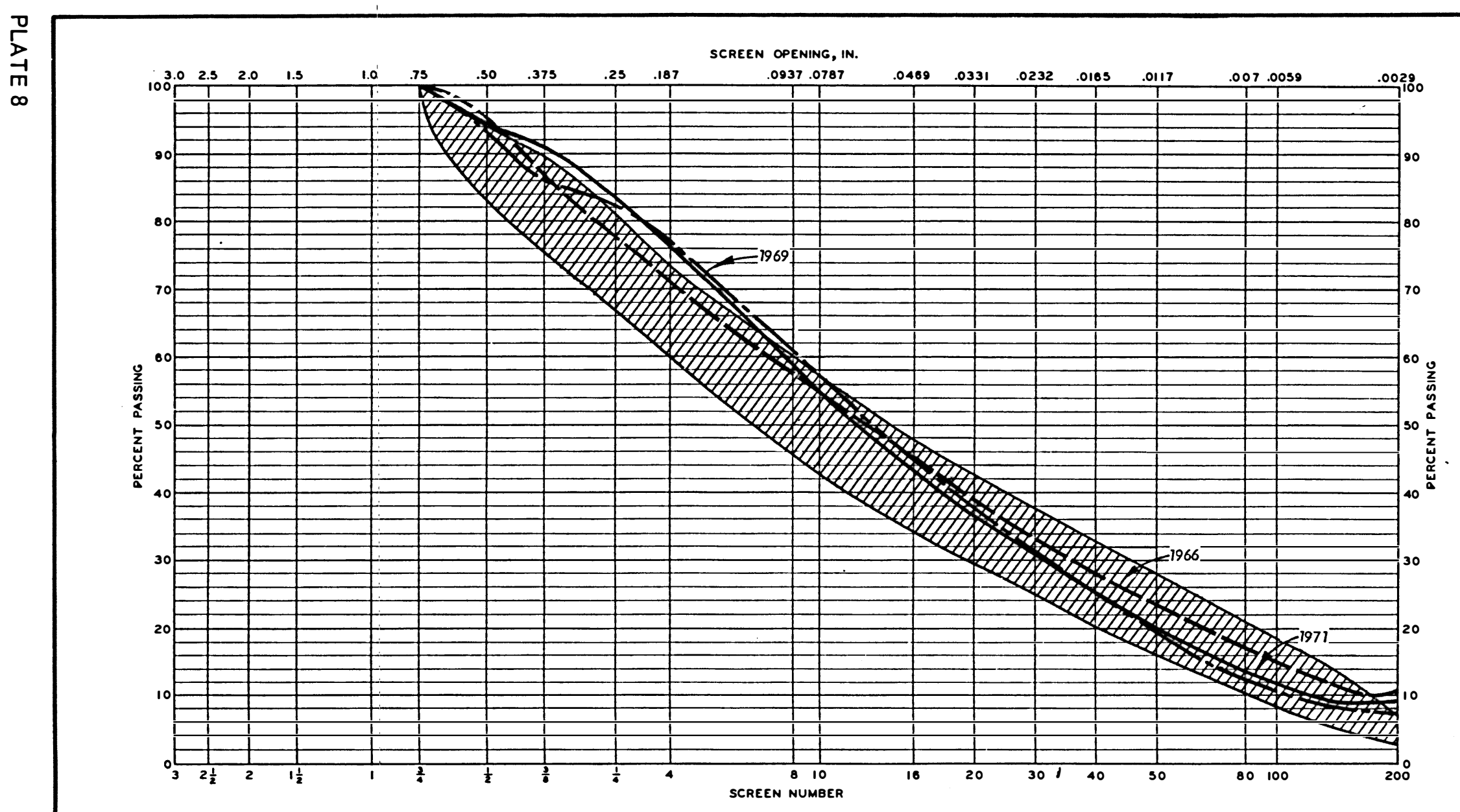

GRADATION OF TAR-RUBBER|PAVEMENT LANGLEY AFB 
SCREEN OPENING, IN.

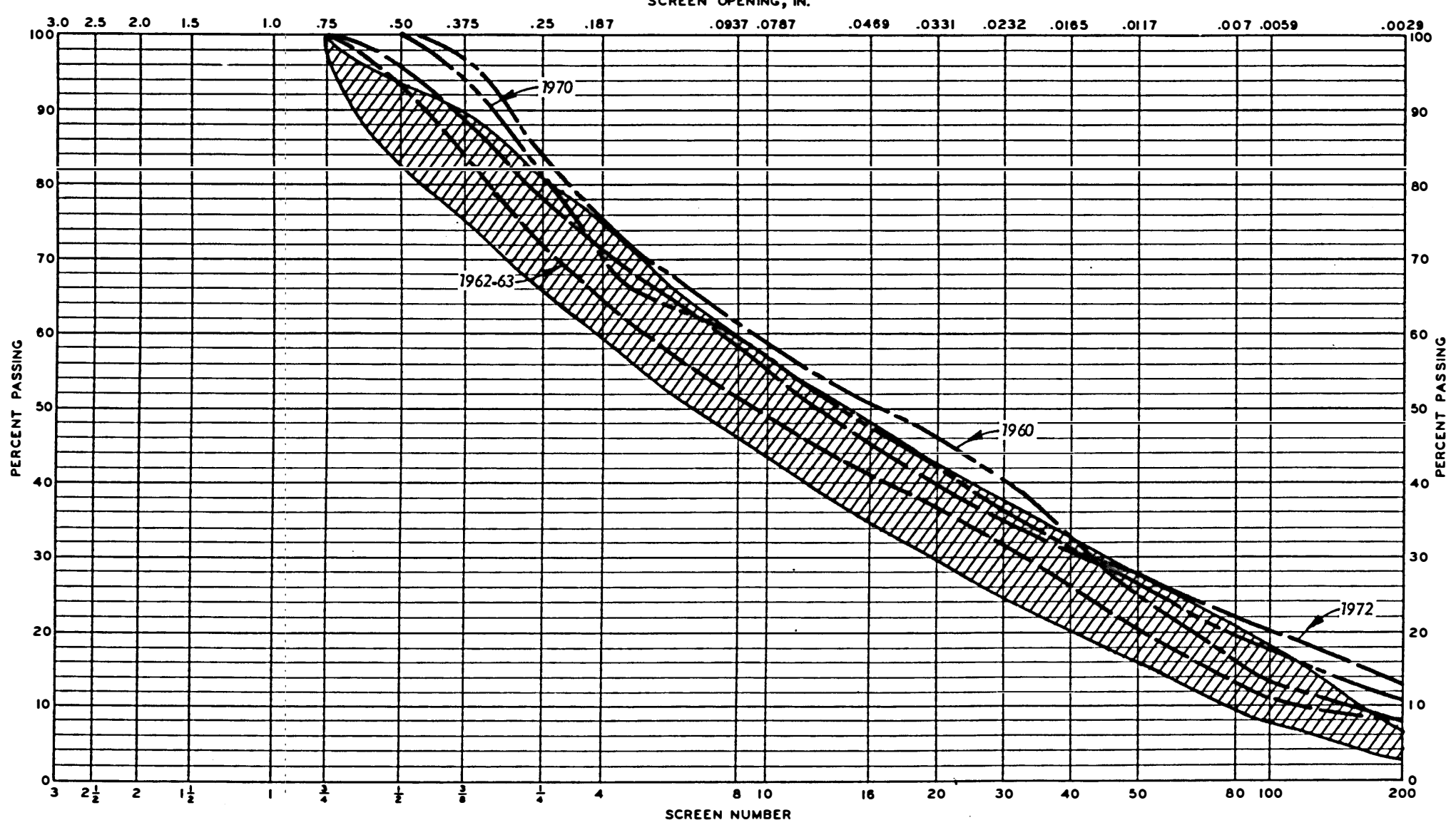

GRADATION OF TAR-RUBBER PAVEMENT WRIGHT-PATTERSON AFB 


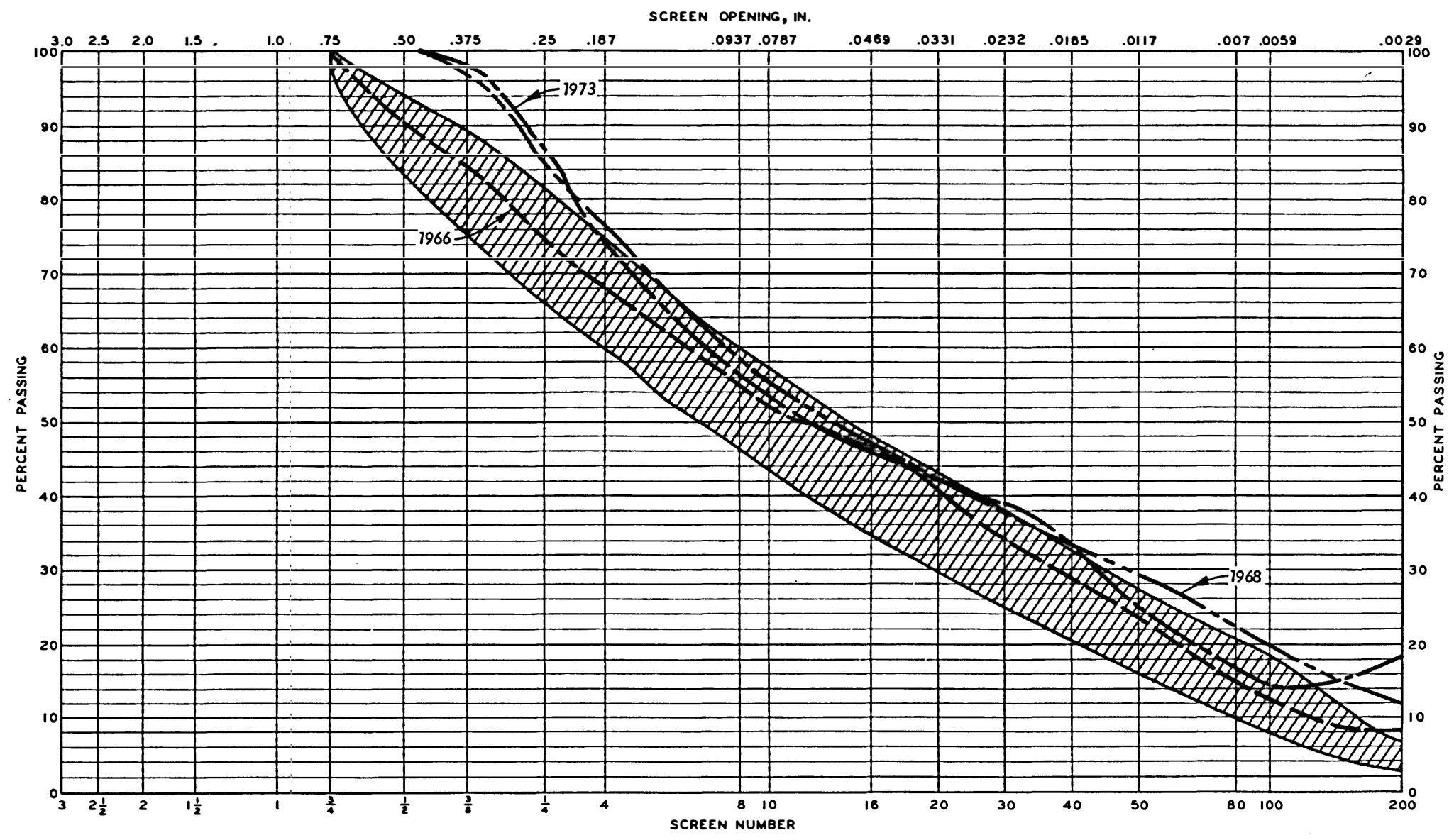

GRADATION OF TAR-RUBBER PAVEMENT RICKENBACKER AFB 


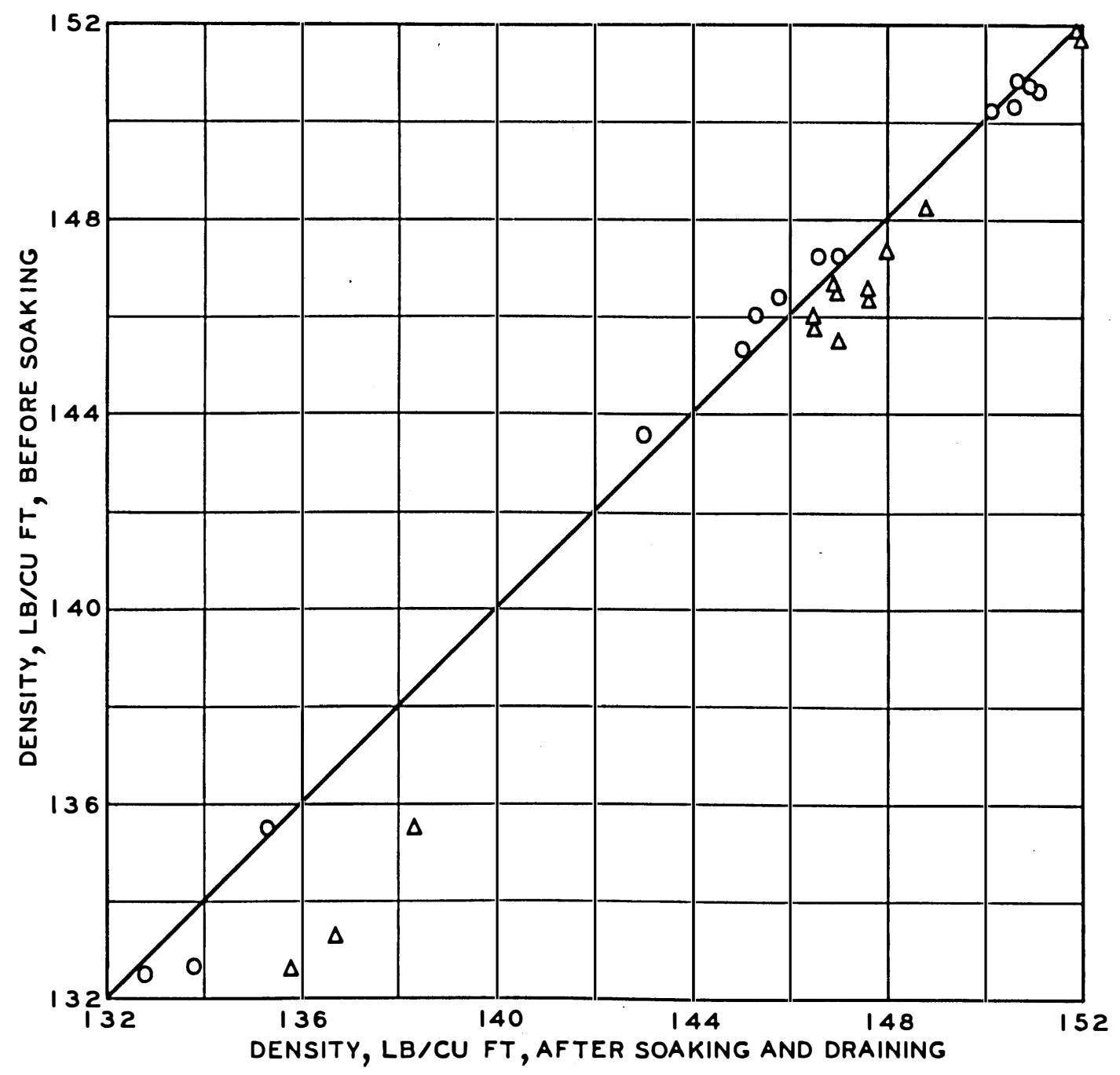

EFFECTS OF JET FUEL AND HYDRAULIC FLUID ON DENSITY SAMPLES SOAKED 5 DAYS AND ALLOWED TO DRAIN 5 DAYS 


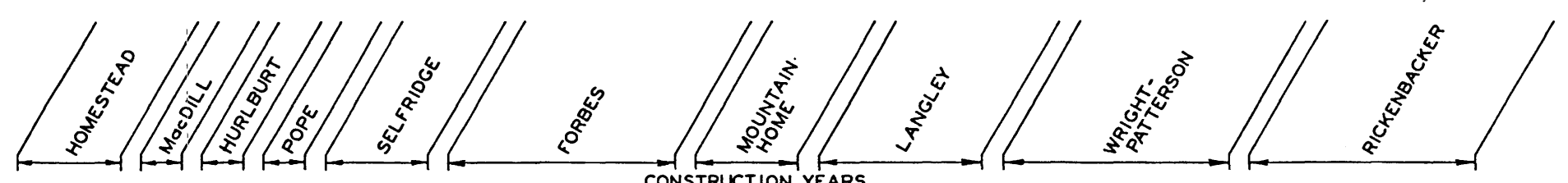

1955- 1966- 1970- 1968-

CONSTRUCTION YEARS

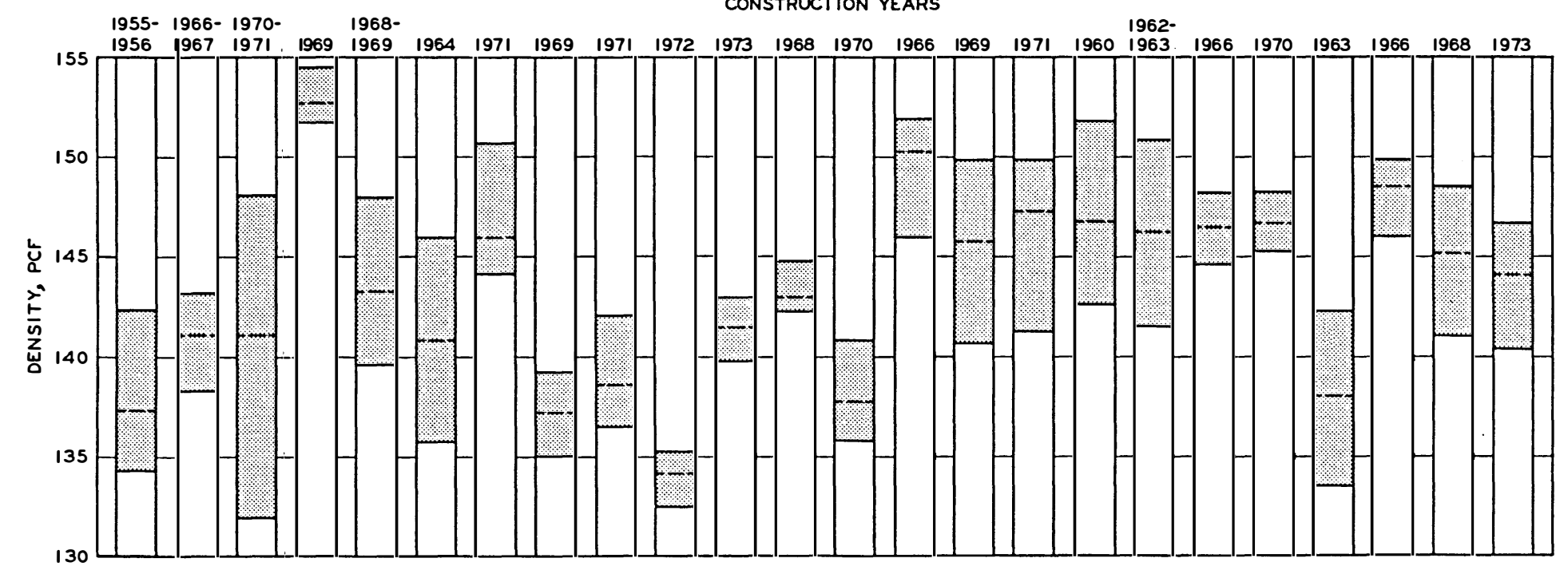

NOTE: - - DENOTES AVERAGE

CHART SHOWING

RANGE IN DENSITY FOR EACH CONSTRUCTION YEAR 


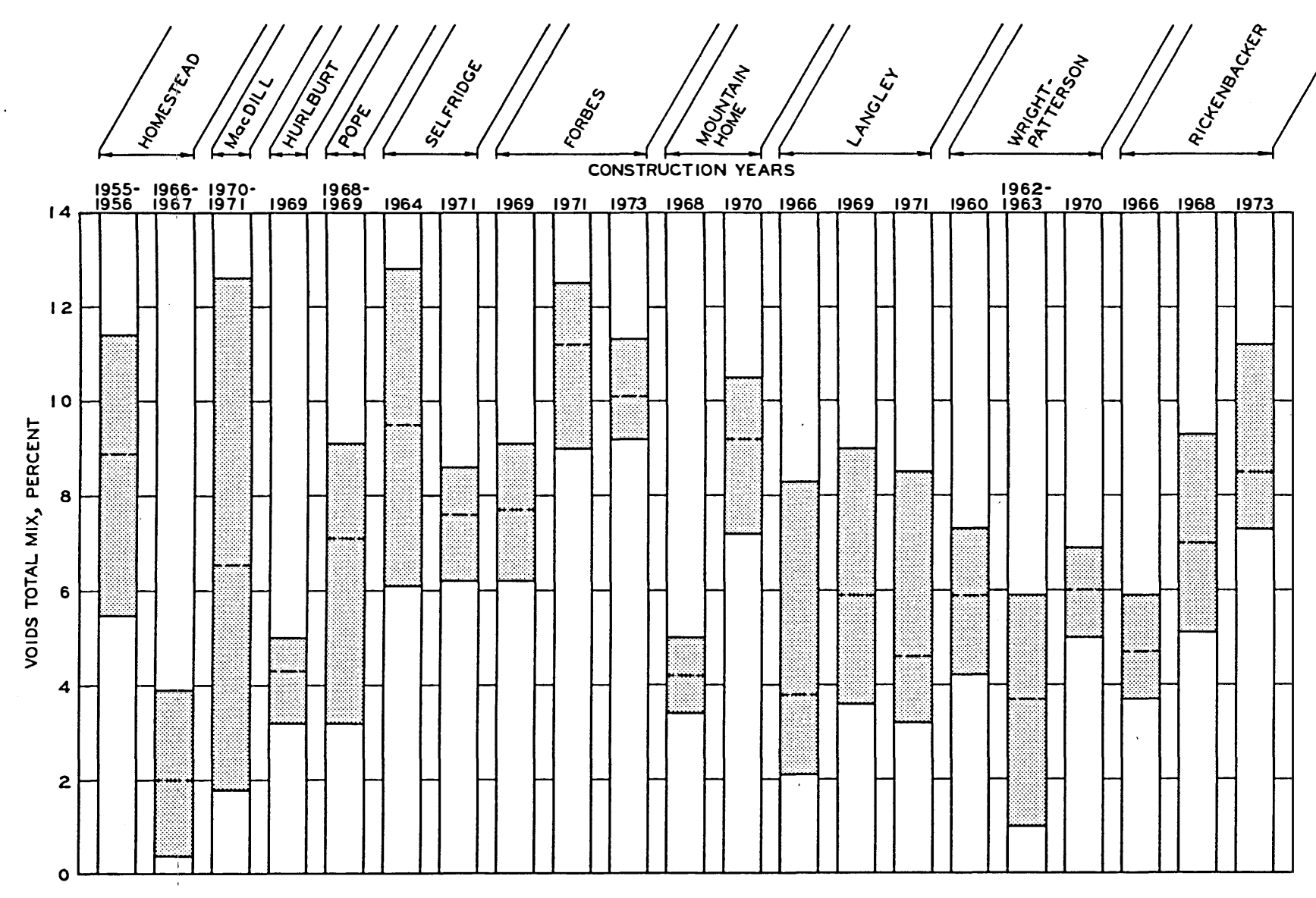

$\frac{0}{5}$
$\frac{D}{7}$
$\frac{m}{\omega}$

NOTE: - -- DENOTES AVERAGE

CHART SHOWING RANGE IN VOIDS FOR EACH CONSTRUCTION YEAR 